MARCELO FONSECA VICENTINI

\title{
SUBCAPITALIZAÇÃO NO DIREITO TRIBUTÁRIO BRASILEIRO
}

DISSERTAÇÃO DE MESTRADO

Orientador: Prof. Dr. Roberto Quiroga Mosquera

UNIVERSIDADE DE SÃO PAULO

FACULDADE DE DIREITO

SÃO PAULO 


\title{
SUBCAPITALIZAÇÃO NO DIREITO TRIBUTÁRIO BRASILEIRO
}

\author{
Trabalho apresentado à Banca Examinadora da \\ Universidade de São Paulo como requisito parcial \\ para obtenção do título de MESTRE em Direito \\ Econômico e Financeiro, sob a orientação do \\ Professor Doutor Roberto Quiroga Mosquera.
}

UNIVERSIDADE DE SÃO PAULO

FACULDADE DE DIREITO

\author{
SÃO PAULO
}

2014 
Autorizo a reprodução e divulgação total ou parcial deste trabalho, por qualquer meio convencional ou eletrônico, para fins de estudo e pesquisa, desde que citada a fonte.

Serviço de Biblioteca e Documentação

Faculdade de Direito da Universidade de São Paulo

\begin{tabular}{|l}
\hline Vicentini, Marcelo Fonseca \\
Subcapitalização no direito tributário brasileiro / Marcelo \\
Fonseca Vicentini . - - São Paulo: USP / Faculdade de Direito, \\
2014 \\
170 f. \\
Orientadora: Prof. Dr. Roberto Quiroga Mosquera. \\
Dissertação (Mestrado), Departamento de Direito \\
Econômico e Financeiro da Faculdade de Direito da \\
Universidade de São Paulo, USP, Programa de Pós-Graduação \\
em Direito, 2014. \\
1. Direito tributário. 2. Juros 3. Empréstimo. \\
I. Mosquera, Roberto Quiroga. II. Universidade de São Paulo, \\
Faculdade de Direito, Programa de Pós-Graduação em \\
Direito. III. Título. \\
CDU 351.713 (043)
\end{tabular}


Nome: VICENTINI, Marcelo Fonseca

Título: Subcaptalização no direito tributário brasileiro

Trabalho apresentado à Banca Examinadora da Universidade de São Paulo como requisito parcial para obtenção do título de MESTRE em Direito Econômico e Financeiro, sob a orientação do Professor Doutor Roberto Quiroga Mosquera.

Aprovado em:

Banca Examinadora

Prof. Dr. Instituição

Julgamento Assinatura:

Prof. Dr. Instituição

Julgamento Assinatura:

Prof. Dr. Instituição

Julgamento Assinatura: 


\section{DEDICATÓRIAS}

À Lissandra, com todo o meu amor Ao Lucas, nossa razão de viver Ao Walter e Aparecida, a quem espero sempre orgulhar

Ao Prof. Roberto Quiroga Mosquera, Que, mais que um professor, é um exemplo a ser seguido Aos Profs. Luís Eduardo Schoueri e Paulo Ayres Barreto, Por todos os ensinamentos e debates sempre acalorados e enriquecedores 


\section{RESUMO}

Trata-se de dissertação para obtenção do grau de Mestre perante a Faculdade de Direito da Universidade de São Paulo, versando sobre as regras de Subcapitalização no Direito Tributário Brasileiro.

O tema central da dissertação pode ser resumido da seguinte maneira: o que são regras de subcapitalização e qual a real necessidade de estabelecimento destas no direito tributário brasileiro, tendo em vista o ordenamento jurídico precedente à publicação das referidas normas.

Iniciaremos o trabalho com a contextualização histórica do tema e, na sequência, analisaremos a legislação relativa à subcapitalização no direito comparado, estudando os princípios norteadores, bem como as regras específicas existentes nas diversas localidades estudadas.

Estudaremos ainda o sistema jurídico tributário precedente às regras de subcapitalização, bem como analisaremos caso julgado pelo Conselho de Contribuintes, conhecido como caso Colgate/Kolynos, considerado o principal julgado a respeito da matéria no Brasil e que, certamente, foi relevante para o estabelecimento das regras de subcapitalização no Brasil.

Por fim, após descrição minuciosa da legislação estabelecida no Brasil, será realizada avaliação crítica, tendo em vista as imperfeições e lacunas verificadas na norma introdutora das regras de subcapitalização no Brasil, a saber, Medida Provisória no 472/09, de 16 de dezembro de 2009, posteriormente convertida na Lei ${ }^{\circ} 12.249$, de 14 de junho de 2010, bem como da regulamentação expedida pela Receita Federal do Brasil por meio da Instrução Normativa no 1.154 , de 12 de maio de 2011. 


\begin{abstract}
This is a dissertation to obtain the Master before the University of São Paulo Law School, about thin capitalization rules in Brazilian Tax Law.

The central theme of the dissertation can be summarized this way: what are thin capitalization rules and what is the real need of establishing such rules in the Brazilian Tax Law, considering the previous existing law system.
\end{abstract}

The starting point will be the historical contextualization of the theme and, in the sequel, we will analyze the thin capitalization rules in the foreign law, studying the guiding principles and the existing specific rules in the places studied.

It will be studied the legal tax system precedent to thin capitalization rules, as well as it will be analyzed a case judged by Council Taxpayers, known as case Colgate/Kolynos, considered the principal case related to the subject in Brazil which, certainly, was relevant for establishing the thin capitalization rules in Brazil.

Lastly, it will also be analyzed in details the rules established in Brazil, including a critical evaluation, in the view of imperfections and gaps verified in the rules which established thin capitalization rules in Brazil, namely, Provisory Measure $n^{\circ}$ 472, 2009 December $16^{\text {th }}$, converted into Law $\mathrm{n}^{\mathrm{o}} 12.249,2010$ June $14^{\text {th }}$, and regulation issued by Federal Tax Authorities, Normative Instruction $n^{\circ} 1.154,2011$ May 12. 


\section{SUMÁRIO}

INTRODUÇÃO 11

1. Globalização 12

1.1 Integração dos mercados e os grupos multinacionais 14

$\begin{array}{ll}1.2 \text { Estrutura organizacional dos grupos multinacionais } & 16\end{array}$

$\begin{array}{ll}1.3 \mathrm{O} \text { direito e a globalização } & 18\end{array}$

$\begin{array}{ll}\text { 1.3.1 Safe haven ou Safe harbour } & 19\end{array}$

$\begin{array}{ll}\text { 1.3.2 Arm's Length } & 20\end{array}$

2. Formas de custear investimentos empresariais e consequências fiscais 24

2.1 Capital 26

2.1.1 Consequências fiscais dos dividendos $\quad 27$

$\begin{array}{ll}2.2 \text { Empréstimos } & 30\end{array}$

2.2.1 Limite dos juros nos contratos de empréstimos no direito comparado 32

2.2.2 Limite dos juros nos contratos de empréstimos no direito brasileiro 33

2.2.3 Consequências fiscais dos juros

3. Aspectos gerais da subcapitalização 39

3.1 Safe haven ou safe harbour e as regras de subcapitalização 42

3.2 Arm's length e as regras de subcapitalização 44

3.3 Experiência em outros países 46

$\begin{array}{ll}\text { 3.3.1 OCDE } & 47\end{array}$

3.3.1.1 Relevância da OCDE para as regras de subcapitalização 48

3.3.1.2 Subcapitalização no âmbito da OCDE 49

3.3.1.3 Subcapitalização e a convenção modelo 51

3.3.1.4 Princípio arm's length e as regras de subcapitalização segundo a OCDE 53

3.3.2 Estados Unidos

$\begin{array}{ll}3.3 .3 \text { Europa } & 59\end{array}$

3.3.3.1 Alemanha $\quad 59$

3.3.3.2 Reino Unido $\quad 62$

$\begin{array}{ll}3.3 .3 .3 \text { França } & 67\end{array}$

3.3.4 Países Emergentes $\quad 69$

$\begin{array}{ll}\text { 3.3.4.1 China } & 69\end{array}$ 
3.3.4.2 Rússia

$\begin{array}{ll}\text { 3.3.4.3 Índia } & 74\end{array}$

3.3.4.4 Argentina 74

3.3.4.5 África do Sul $\quad 76$

4. Antecedentes da Subcapitalização no Brasil 78

4.1 Histórico das normas para a dedução de despesas financeiras antes do $\begin{array}{ll}\text { estabelecimento das normas de subcapitalização } & 78\end{array}$

4.2 Distribuição disfarçada de lucros - DDL 82

4.3 Estímulo à capitalização das empresas - Juros sobre o capital próprio 86

4.4 Julgamento do Conselho de Contribuintes - caso "Colgate / Kolynos"

- análise da relevância para o entendimento da matéria 89

5. Normas brasileiras contra a subcapitalização 94

$\begin{array}{ll}5.1 \text { Contexto legislativo } & 95\end{array}$

5.2 Regras de subcapitalização adotadas no direito brasileiro 96

5.2.1 Conceito básico da norma 96

5.2.1.1 Despesa necessária no âmbito das regras de subcapitalização 99

$\begin{array}{ll}\text { 5.2.1.2 Juros } & 102\end{array}$

$\begin{array}{ll}\text { 5.2.1.3 Endividamento } & 105\end{array}$

$\begin{array}{ll}\text { 5.2.1.4 Credor residente no exterior } & 107\end{array}$

5.2.2 Artigo 24 - Juros pagos ou creditados por fonte situada no Brasil à

$\begin{array}{ll}\text { pessoa física ou jurídica vinculada } & 109\end{array}$

$\begin{array}{ll}\text { 5.2.2.1 Conceito de pessoa vinculada } & 109\end{array}$

5.2.2.2 Limites de endividamento com pessoa jurídica vinculada no exterior 111

5.2.2.3 Cumulação de limites de endividamento 112

5.2.3 Artigo 25 - Credor residente em país ou dependência com tributação $\begin{array}{ll}\text { favorecida ou sob regime fiscal privilegiado } & 113\end{array}$

5.2.3.1 Conceito de país ou dependência com tributação favorecida e $\begin{array}{ll}\text { regime fiscal privilegiado } & 113\end{array}$

5.2.3.2 Limites de endividamento com credor residente em país ou dependência com tributação favorecida ou sob regime fiscal privilegiado 115

5.2.4 Avalista, fiador, procurador ou qualquer interveniente 116

5.2.5 Operações de repasse realizadas por instituições financeiras 119 
5.3 Normas de subcapitalização e os tratados para evitar a dupla tributação assinados pelo Brasil

5.4 Subcapitalização como norma tributária indutora

6. Crítica às regras de subcapitalização adotadas no direito brasileiro e sugestões de melhorais com base no direito comparado

6.1 (Des) Necessidade da norma

6.1.1 Conceito de despesa necessária antes e depois da norma

6.1.2 Juros sobre o capital próprio

6.1.3 Norma antielisivia específica

6.2 Aplicação de ficção ou presunção absoluta

$\begin{array}{ll}6.3 \text { Coeficientes fixos aplicados a todos os setores } & 146\end{array}$

6.4 Limite de Dedutibilidade x Patrimônio Líquido Negativo 147

6.5 Operações com filiais, sucursais e subsidiárias domiciliadas no exterior $\quad 148$

6.6 Vigência e Eficácia da norma

6.6.1 Aplicação do $\S 2^{\circ}$ do art. 62 da Constituição Federal às regras de

Subcapitalização

6.6.2 Imposto de Renda 154

6.6.3 Contribuição Social sobre o Lucro Líquido 156

$\begin{array}{ll}\text { CONCLUSÃO } & 162\end{array}$

$\begin{array}{ll}\text { BIBLIOGRAFIA } & 164\end{array}$ 


\section{INTRODUÇÃO}

O presente trabalho tratará da subcapitalização no direito tributário brasileiro, tema este que nos leva ao debate acerca do nível adequado de endividamento de empresas dos mais variados setores, bem como se o Estado pode (ou deve) limitar empréstimos e financiamentos domésticos e internacionais obtidos por estas.

As regras de subcapitalização existem há muitos anos no ordenamento jurídico estrangeiro e representam uma realidade que demorou a ser incorporada no ordenamento jurídico brasileiro, o que somente ocorreu em 2009, com a publicação da Medida Provisória nº 472/09.

Em que pese a tardia incorporação ao ordenamento jurídico brasileiro, fato este que poderia denotar o estudo prévio e detalhado do tema pelas autoridades fiscais e com o conseqüente primor técnico e jurídico decorrente da análise detida de determinado assunto, o que se observou na prática foi o estabelecimento de regras incompletas e com parâmetros fixos, aplicadas indistintamente a todos os setores da economia e dissociadas de condições de mercado, o que pode levar a uma série de injustiças e colocar em cheque a adequação da norma aos princípios constitucionais.

Além das eventuais inconstitucionalidades e imperfeições brevemente descritas acima, o ordenamento jurídico existente à época da publicação da Medida Provisória $\mathrm{n}^{\circ}$ 472/09 nos leva a questionar a própria necessidade do estabelecimento de regras de subcapitalização no Brasil, especialmente por conta da existência prévia da figura dos juros sobre o capital próprio.

Em apertada síntese, esse é o pano de fundo do trabalho proposto: analisar detalhadamente as normas de subcapitalização recentemente estabelecidas no Brasil, realizando a devida ponderação quanto à sua adequação e necessidade. 


\section{Globalização}

O tema subcapitalização surge em decorrência de um fenômeno conhecido como globalização, fenômeno este com profundas implicações nas mais variadas áreas do conhecimento e nos mais diversos setores da vida social.

Observamos que com a globalização, as decisões de produção e comércio internacional ficaram intimamente interligadas e a chamada transnacionalização de empresas espalhou-se pelo mundo inteiro, sendo que a maior parte dos produtos que chegam ao mercado hoje é transacionável internacionalmente ou depende pesadamente de componentes transacionáveis. ${ }^{1}$

Frente a esta nova realidade, as relações comerciais e jurídicas a serem reguladas e normatizadas pelo direito não mais se limitam ao espaço físico de cada país ou nação, e o direito, como inicialmente idealizado e estabelecido, precisa se ajustar a essa nova realidade.

Seguindo esta linha, Arnold Wald escreveu que não adianta afirmar "não quero ser globalizado", pois não se trata mais de uma escolha, trata-se de reconhecer o fato e de tomar as medidas cabíveis no plano econômico, ético e, especialmente, jurídico. ${ }^{2}$

Esta também é a opinião de José Eduardo Faria ao afirmar que o pensamento jurídico precisa encontrar alternativas para a exaustão paradigmática de seus principais modelos teóricos e analíticos, pois vencida a fase inicial do desafio da transnacionalização dos mercados de insumos, produção, capitais, finanças e consumo, vive-se atualmente a etapa relativa às mudanças jurídicas e institucionais necessárias para assegurar o funcionamento efetivo da economia globalizada. ${ }^{3}$

\footnotetext{
${ }^{1}$ SILBER, Simão Davi. “A globalização dos mercados”. In: VASCONCELLOS, Marco Antonio Sandoval de; LIMA, Miguel; SILBER, Simão Davi (org.). Gestão de Negócios Internacionais. $2^{\circ}$ Ed. São Paulo: Saraiva, 2010, p. 17.

${ }^{2}$ WALD, Arnold. "Alguns Aspectos Jurídicos da Globalização Financeira”. In: MOSQUERA, Roberto Quiroga (coord.) Aspectos Atuais do direito do mercado financeiro e de capitais. São Paulo: Dialética, 1999, p. 11.

${ }^{3}$ FARIA, José Eduardo. O direito na economia globalizada. São Paulo: Malheiros, 2004, p. 13-14.
} 
Os comentários de Arnold Wald e o desafio apontado por José Eduardo Faria nos levam a conclusão que o direito precisa dar uma resposta satisfatória a nova realidade e que, ao mesmo tempo, atenda de maneira adequada o que se espera e exige dele.

Por outro lado, podemos também afirmar que é impossível exigir resposta adequada dos legisladores a todas as questões decorrentes desta nova realidade e estes devem regular, ao menos, os assuntos mais relevantes e que possam impactar de maneira significativa o novo mercado.

Neste contexto, dentre as diversas questões a serem reguladas, se destacam as transações entre empresas pertencentes ao mesmo grupo econômico e sediadas em diferentes países ou, em termos mais técnicos, a relação comercial e jurídica entre partes relacionadas ou vinculadas. ${ }^{4}$

O tema ganha relevância na medida em que a relação entre partes relacionadas ou vinculadas, na maioria das vezes, não sofre a interferência do mercado, pois há possibilidade de definição de preços, parâmetros e limites de acordo com as conveniências e interesses das partes envolvidas, sem a necessária observância das condições de mercado para essas definições. Assim, cabe aos legisladores dos diversos países integrantes destas relações criarem mecanismos de verificação, estabelecendo critérios para avaliação da adequação das mesmas às condições de mercado. ${ }^{5}$

Um dos mecanismos de verificação adotado é a comparação dos preços praticados entre partes relacionadas com preços de mercado, mecanismo esse conhecido como arm's length. De maneira extremamente simplista, o princípio arm's length busca estabelecer limites, de maneira que a negociação entre empresas vinculadas seja realizada dentro de parâmetros e condições de mercado sendo, portanto, compatíveis com os preços e condições que seriam adotados, caso a operação fosse realizada entre empresas não vinculadas. 6

\footnotetext{
${ }^{4}$ BARRETO, Paulo Ayres. Imposto sobre a renda e preços de transferência. São Paulo: Dialética, 2001, p. 97.

${ }^{5}$ SCHOUERI, Luís Eduardo. Preço de Transferência no direito tributário brasileiro. $2^{\circ}$ edição, rev. e atual. São Paulo: Dialética, 2006, p. 11-12.

${ }^{6}$ SCHOUERI, Luís Eduardo. Ob. Cit. (nota 5), p. 22-36.
} 
Encontramos referência ao principio arm's length em diversas regras tributárias ao redor do mundo, sendo relevante citar as referências existentes no Modelo de Convenção Fiscal sobre o Rendimento e o Capital da Organização para a Cooperação e Desenvolvimento Econômico - OCDE, o que justifica a adoção do princípio por grande parte dos países membros desta Organização (bem como países não membros), para diversas legislações tributárias, tais como: subcapitalização e preço de transferência. ${ }^{7}$

Outro mecanismo de verificação adotado internacionalmente para controle das transações entre partes relacionadas ou vinculadas é conhecido como safe harbour ou safe haven. A expressão é geralmente usada para referir situações nas quais determinadas categorias de contribuintes, caso preencham determinadas condições, podem se submeter a regras mais simples que os demais.

Encontramos referência ao safe haven, por exemplo, no General Report de 1996 da International Fiscal Association - IFA, que esclarece que no âmbito das regras de subcapitalização, o safe haven corresponde ao conceito de proporção fixa entre endividamento e capital. ${ }^{8}$

Tecemos estes breves comentários iniciais para estabelecer a origem e a justificativa do tema proposto, pois há relação direta entre os mecanismos de verificação da validade de relações entre empresas vinculadas (tais como arm's length e safe haven) e as regras de subcapitalização, como demonstraremos ao longo do presente trabalho.

1.1 Integração dos mercados e estabelecimento de grupos econômicos multinacionais

Conforme nos referimos linhas atrás, uma das conseqüências da globalização é a integração de diversos mercados, propiciando intensa circulação de bens, serviços e capitais.

\footnotetext{
${ }^{7}$ ORGANISATION FOR ECONOMIC CO-OPERATION AND DEVELOPMENT - OECD. Model Tax Convention on Income and on Capital - Condensed Version. Paris: OECD, 2010, p. 68-396.

${ }^{8}$ INTERNATIONAL FISCAL ASSOCIATION - IFA. "International aspects of thin capitalization". In Cahiers de Droit Fiscal International. Vol. 81b. Geneva: IFA, 1996, p. 105.
} 
Em decorrência deste processo, observamos em intensidade cada vez maior, a criação de empresas multinacionais bem como de grupos econômicos complexos, com grande diversidade de estruturas societárias e as mais variadas estruturas de capital.

Interessante observar que além destas mudanças, a globalização mudou também a dinâmica do comércio mundial, pois enquanto a produção mundial cresceu 6 (seis) vezes nos últimos 40 anos, os fluxos comerciais cresceram 12 (doze) vezes. Em outras palavras, o comércio internacional vem apresentando um dinamismo mais forte do que a produção mundial e os mercados estão ficando cada vez mais integrados, sendo que a maioria dos países está mais dependente de compras e vendas externas. ${ }^{9}$

Arnold Wald apresenta explicação à situação constatada acima, e esclarece que na medida em que se abriram as fronteiras, as distâncias foram abolidas, bem como desapareceram totalmente as barreiras alfandegárias e os regimes de fiscalização de entrada e saída de capitais, propiciando um movimento crescente dos fluxos comerciais. ${ }^{10}$

Como consequência, numa manifestação por vezes excessiva do liberalismo econômico, os recursos financeiros passaram a buscar sempre a melhor rentabilidade a curto prazo, em prejuízo de investimentos produtivos com lucros menores ou menos imediatos, em outras palavras, o movimento internacional de capital especulativo passou a ser mais importante que o fluxo do chamado capital produtivo investido a médio ou longo prazo. $^{11}$

Frente a essa nova dinâmica do comércio mundial e do fluxo de capital, as tradicionais empresas nacionais foram impactadas de maneira relevante e tiveram que se adaptar a uma nova realidade, não apenas como uma decorrência natural do novo fenômeno, mas também como uma forma de sobrevivência frente a grandes grupos multinacionais surgidos e, com o passar do tempo, os próprios grupos multinacionais passaram pelo mesmo processo de adaptação, tamanha a força imposta pela globalização.

\footnotetext{
${ }^{9}$ SILBER, Simão Davi. “A globalização dos mercados”. In: VASCONCELLOS, Marco Antonio Sandoval de; LIMA, Miguel; SILBER, Simão Davi (org.). Ob. Cit., p. 17-18.

${ }^{10}$ WALD, Arnold. “Alguns Aspectos Jurídicos da Globalização Financeira”. In: MOSQUERA, Roberto Quiroga (coord.). Ob. Cit., p. 12.

${ }^{11}$ WALD, Arnold. "Alguns Aspectos Jurídicos da Globalização Financeira”. In: MOSQUERA, Roberto Quiroga (coord.). Ob. Cit., p. 12.
} 
Nesta linha, afirma José Eduardo Faria que como decorrência do amplo processo de racionalização organizacional, decisório e operacional, a tradicional empresa multinacional, que se caracterizava por ter uma estrutura decisória rigidamente hierarquizada, que se reproduzia em todos os países onde atuava, é gradativamente substituída pela companhia global ou pela corporação transnacional que tem estruturas decisórias bem mais leves e mais ágeis, de caráter basicamente multidivisional. ${ }^{12}$

Essa também é a opinião de Heleno Tôrres. Afirma o professor que em uma economia como a que se evidencia na atualidade, não mais limitada aos restritos confins nacionais, mas que se expande além dos âmbitos continentais, os problemas relativos à eficiência operativa têm assumido uma importância fundamental para a definição dos critérios organizacionais das empresas, principalmente aquele da competitividade em mercados internacionais, cujo êxito, em muitos casos, depende da política fiscal adotada pelo Estado. $^{13}$

Resta claro que a integração dos mercados tem forte influência nas empresas e nos grupos econômicos e, mesmo empresas multinacionais, precisaram se adaptar a nova realidade. Por seu turno, a atual organização dos grupos econômicos multinacionais adiciona novo elemento ao mundo corporativo: a busca por eficiência a qualquer preço, situação esta que chama a atenção do direito e precisa ser regulada.

\subsection{Estrutura organizacional dos grupos multinacionais}

Como consequência do processo descrito acima, as companhias globais ou corporações transnacionais são, hoje, altamente flexíveis e passam a representar não mais um agregado de atividades em nível de países, dependentes de estruturas burocráticas e rígidas mas, pelo contrário, passam a ter uma forma de negócios desagregado, administrado com um processo interligado, controlado por informações compartilhadas e organizado horizontalmente por assunto, produto ou serviço. ${ }^{14}$

\footnotetext{
${ }^{12}$ FARIA, José Eduardo. Ob. Cit. p 72.

${ }^{13}$ TÔRRES, Heleno. Pluritributação Internacional sobre as Rendas de Empresas. $2^{\text {a }}$ ed. rev., atual. e amp. São Paulo: Revista dos Tribunais, 2001, p. 174.

${ }^{14}$ FARIA, José Eduardo. Ob. Cit. p 72.
} 
A partir da nova estrutura das companhias globais ou corporações transnacionais, os atores do comércio mundial e as relações comerciais também sofreram mudanças e uma parcela relevante dessas transações passou a ocorrer no âmbito das próprias companhias ou corporações, sem mais haver a necessidade de interferência de terceiros nessas relações.

Com isso, observamos que após a segunda guerra mundial, em decorrência da liberalização comercial, houve uma expansão sem precedentes no comercio internacional, ultrapassando o crescimento do PIB mundial. Por seu turno, uma parcela relevante do comércio mundial passou a ocorrer intrafirma, comandada pelo investimento externo, na medida em que as empresas procuram aumentar suas escalas de operação, reduzir custos e ampliar suas participações nos mercados nacionais e internacionais.

Esse fenômeno da desverticalização da atividade produtiva está no amago da estratégia das empresas transnacionais, que procuram distribuir suas atividades produtivas em escala mundial, selecionando os países de acordo com vantagens comparativas em relação a determinados segmentos da produção. ${ }^{15}$

O novo tipo de estrutura permite ao conglomerado transacional ou companhia global, estabelecer entre suas diferentes unidades, um intrincado conjunto de relações horizontais e de transações comerciais cujo valor ou preço não mais é determinado pelo mercado, mas por critérios de ordem basicamente contábil e financeira, a partir dos custos de produção.

Na medida em que essas unidades recebem insumos e escoam sua produção no âmbito do próprio conglomerado, os preços de transferência - mais precisamente, de cessão interna - são determinados discricionariamente pela administração central, o que dá aos conglomerados uma enorme autonomia frente aos mercados, aos sistemas regulatórios e às autoridades fiscais nacionais, pulverizando assim as possibilidades de controle sobre sua contabilidade, sobre seus fluxos horizontais e verticais de pagamentos e sobre suas remessas de capital. ${ }^{16}$

${ }^{15}$ SILBER, Simão Davi. "A globalização dos mercados”. In: VASCONCELLOS, Marco Antonio Sandoval de; LIMA, Miguel; SILBER, Simão Davi (org.). Ob. Cit., p. 18.

${ }^{16}$ FARIA, José Eduardo. Obra Cit., p. 74-75. 
Como resultado, todas essas medidas acabaram propiciando, num espaço de tempo bastante curto, a maximização do nível de desempenho de todas as formas sociais de trabalho e produção. ${ }^{17}$

Por outro lado, a maximização do nível de desempenho leva em conta, cada vez mais, critérios internos de aferição, sem que necessariamente, se observe parâmetros de mercado para a definição da estrutura a ser estabelecida ou definição dos preços a serem praticados, proporcionando grande discricionariedade aos conglomerados organizacionais.

\section{$1.3 \mathrm{O}$ direito e a globalização}

O processo de globalização e, especialmente, a nova estrutura organizacional dos grupos multinacionais descritos anteriormente, nos levam a observação de diversos fatos e situações merecedores de atenção e regulação pelo direito.

Como dissemos anteriormente, merecem destaque as relações comerciais e jurídicas entre partes relacionadas ou vinculadas na medida em que, na maioria das vezes, essas relações não sofrem interferência do mercado, havendo a possibilidade de definição de preços, parâmetros e limites de acordo com as conveniências e interesses das partes envolvidas, sem que se observem as condições de mercado para essas definições.

Desta forma, cabe aos legisladores dos diversos países integrantes destas relações, criarem mecanismos de verificação, estabelecendo conceitos e critérios para avaliação da adequação das mesmas às condições de mercado. ${ }^{18}$

Considerando a relevância do tema, bem como a necessidade de atuação conjunta dos países sede das partes relacionadas ou vinculadas para evitar desvios nas respectivas transações, observamos que dois mecanismos vêm sendo largamente adotados como parâmetro e limite para essas relações, são eles: safe harbour ou safe haven e arm's length, mecanismos esses que passamos a detalhar nos próximos itens.

\footnotetext{
${ }^{17}$ FARIA, José Eduardo. Obra Cit., p. 74-75.

${ }^{18}$ SCHOUERI, Luís Eduardo. Ob. Cit. (nota 5), p. 11-12.
} 


\subsubsection{Safe harbour ou Safe haven}

Como afirmamos acima, um dos mecanismos adotados internacionalmente para controle dos negócios praticados entre partes relacionadas ou vinculadas é conhecido como safe harbour ou safe haven.

Luís Eduardo Schoueri afirma que a expressão de origem anglo-saxônica safe harbour, que pode vezes pode ser substituída pela expressão sinônima safe haven, denota um porto seguro e originalmente, significa um lugar onde se pode atracar com segurança as embarcações. Por seu turno, em matéria fiscal, são considerados safe harbour ou safe haven, os conjuntos de regras simplificadas, aplicáveis a determinadas categorias de contribuintes, caso preencham determinadas condições. ${ }^{19}$

O breve conceito acima demonstra que a aplicação de regras de safe harbour ou safe haven é bastante abrangente e não se limita a determinado tributo ou obrigação tributária, o que certamente dá liberdade ao legislador para observar situações concretas e complexas para, por meio das referidas regras, conferir maior simplicidade e segurança aos contribuintes.

Observa Luís Eduardo Schoueri que, no contexto da regras que regulam os preços de transferência, as exigências administrativas de um safe harbour podem ir desde uma total exoneração da obrigação de atender às normas nacionais de preços e transferência, até a obrigação de atender diversos deveres instrumentais como condição para fazer jus ao safe harbour. ${ }^{20}$

O relatório da OCDE que define as diretrizes de preços de transferência para empresas multinacionais e administrações tributárias afirma que safe harbour ou safe haven são regras que se aplicam a determina categoria de contribuintes e desobriga estes de cercas obrigações que de outra forma seriam exigíveis. ${ }^{21}$

\footnotetext{
${ }^{19}$ SCHOUERI, Luís Eduardo. Ob. Cit. (nota 5), p. 233.

${ }^{20}$ SCHOUERI, Luís Eduardo. Ob. Cit. (nota 5), p. 233.

${ }^{21}$ ORGANISATION FOR ECONOMIC CO-OPERATION AND DEVELOPMENT - OECD. Transfer Pricing Guidelines for Multinational Enterprises and Tax Administrations. Paris: OECD, 2010, p.160
} 
Na mesma linha, afirma o Luís Eduardo Schoueri que os objetivos gerais das regras de safe harbour, em matéria de preços de transferência são: simplificação das exigências feitas aos contribuintes para determinação dos preços de transferência; conferir certeza aos contribuintes que seus preços de transferência serão aceitos pela Administração e; simplificar a atividade da própria Administração. ${ }^{22}$

No que tange às regras de subcapitalização, encontramos referência ao safe haven no General Report de 1996 da International Fiscal Association - IFA, que esclarece que no âmbito destas regras, o safe haven corresponde ao conceito de proporção fixa entre endividamento e capital, em limites estabelecidos por cada país e, caso atendidos os limites, as subsidiárias podem deduzir os juros pagos para seus acionistas estrangeiros. ${ }^{23}$

Segundo Luís Eduardo Schoueri, a razão da criação das regras de safe harbour não apresenta diferenças fundamentais de outras regras internas que venham, por exemplo, a excluir de execução fiscal dívidas limitadas até certo valor. Neste sentido, ambas apresentam uma utilidade prática simples, mas fundamental para a eficiência da Administração Pública. ${ }^{24}$

Como resumo dos comentários acima, podemos afirmar que a adoção de regras de safe harbour ou safe haven, por diversas legislações tributárias, tem o objetivo de reduzir o ônus que recai sobre Administração e contribuintes, relativamente aquelas operações que observem os limites e condições impostos por essas regras.

\subsubsection{Arm's length}

Outro mecanismo adotado internacionalmente para controle das relações entre partes relacionadas ou vinculadas é conhecido como arm's length.

\footnotetext{
${ }^{22}$ SCHOUERI, Luís Eduardo. Ob. Cit. (nota 5), p. 234.

${ }^{23}$ INTERNATIONAL FISCAL ASSOCIATION - IFA. Ob. Cit. (nota 8), p. 105.

${ }^{24}$ SCHOUERI, Luís Eduardo. Ob. Cit. (nota 5), p. 234.
} 
Segundo Fernando Aurélio Zilveti, a primeira aparição do princípio arm's length se deu no relatório do consultor do Tesouro Americano no Comitê Fiscal da Liga das Nações, Mitchell B. Carroll. ${ }^{25}$

Referido relatório assim dispunha:

Isso pode envolver uma investigação sobre as relações entre a filial local e outros estabelecimentos (filiais ou subsidiárias) da empresa matriz que envolve, por exemplo, a consideração do preço pelo qual os bens foram faturados à filial e as quantias faturadas para a filial por serviços ou representação de parte de despesas gerais estimadas

Com base nesse relatório de Carroll, o Comitê rascunhou, em 1933, um novo tratado multilateral acerca da alocação dos lucros de empresa. ${ }^{26}$

Tendo por base o texto do relatório de Carrol, podemos afirmar que o arm's length busca verificar se a negociação entre empresas vinculadas observou ou não parâmetros e condições de mercado. Desta forma, os preços e condições praticados entre empresas vinculadas em determinada operação, devem ser compatíveis com os preços e condições que seriam adotados, caso a operação fosse realizada entre empresas não vinculadas.

Importante esclarecer uma confusão algumas vezes observada, no sentido de que o padrão arm's length nem sempre exigirá que as empresas vinculadas pratiquem preços nos níveis observados no mercado, pois, em certas ocasiões, mesmo empresas independentes, não praticam os preços ou margens de mercado, justamente porque querem aumentar sua participação neste mercado. $^{27}$

Na medida em que hoje observamos a sua utilização em diversas regras tributárias ao redor do mundo, pode-se afirmar que o arm's length ganhou força ao longo do tempo, sendo relevante citar as referências existentes em diversos artigos do Modelo de Convenção Fiscal sobre o Rendimento e o Capital da OCDE, o que justifica a adoção do princípio por grande parte dos países membros desta Organização (bem como países não

25 ZILVETI, Fernando Aurélio. "Variações sobre o princípio da neutralidade no direito tributário internacional”, in Direito Tributário atual, v. 19, p. 37.

${ }^{26}$ ZILVETI, Fernando Aurélio. Ob. Cit. p. 37.

${ }^{27}$ GREGORIO, Ricardo Marozzi. Arm's length e praticabilidade nos preços de transferência. 2010. Tese (Doutorado em Direito) - Faculdade de Direito, Universidade de São Paulo, São Paulo, 2010, p. 41. 
membro), para diversas regras tributárias, tais como subcapitização e preço de transferência. ${ }^{28}$

No âmbito das regras de subcapitalização, observamos que a adoção do princípio arm's length busca reproduzir o processo de decisão que um credor adotaria para decidir se deveria conceder o empréstimo ou não a determinada empresa, e caso decidisse por conceder o empréstimo, qual seria o montante e a taxa a ser praticada. ${ }^{29}$

Especificamente com relação ao preço de transferência, observamos um capítulo inteiro dedicado ao princípio arm's length no relatório da OCDE que define as diretrizes de preços de transferência para empresas multinacionais e administrações tributárias. Neste capítulo há um resumo das discussões relativas ao princípio, nas quais os países membros da OCDE acordaram que deveria ser usado para fins tributários, tanto pelas empresas multinacionais, como pelas administrações tributárias. ${ }^{30}$

O relatório da OCDE que define as diretrizes de preços de transferência para empresas multinacionais e administrações tributárias busca fundamento no parágrafo 1 do artigo $9^{\circ}$ do Modelo de Convenção Fiscal, e esclarece que a fim de ajustar as receitas às condições de mercado que seriam obtidas entre empresas independentes em transações e situações comparáveis, o princípio arm's length determina que as transações entre empresas ligadas devem ser tratadas como se fossem entidades separadas.

Segundo o relatório, há várias razões para os países membros da OCDE (e países não-membros) adotarem o princípio, pois este garante o tratamento tributário equânime para empresas ligadas e empresas independentes e, sob o aspecto econômico, o princípio em comento promove o crescimento do comércio e investimento internacional. ${ }^{31}$

\footnotetext{
${ }^{28}$ ORGANISATION FOR ECONOMIC CO-OPERATION AND DEVELOPMENT - OECD. Obra. Cit. (nota 7), p. 68-396.

${ }^{29}$ CORONADO, Luis; CHEUNG, Patrick e Kyte, Justin. An overview of arm's length approaches to thin capitalization. International transfer pricing journal - Journals IBFD. Vol. 17, $\mathrm{n}^{\circ}$ 4. Amsterdam, 2010.

${ }^{30}$ ORGANISATION FOR ECONOMIC CO-OPERATION AND DEVELOPMENT - OECD. Ob. Cit. (nota 21), p.31-58.

${ }^{31}$ ORGANISATION FOR ECONOMIC CO-OPERATION AND DEVELOPMENT - OECD. Ob. Cit. (nota 21), p.31-58.
} 
Realizadas considerações conceituais e gerais sobre o arm's length e safe harbour ou safe haven, prosseguiremos com o desenvolvimento de outros aspectos preliminares ao tema objeto do presente trabalho e voltaremos a tratar destes princípios, e mais especificamente da sua aplicação prática, quando discorrermos especificamente sobre as regras que tratam da subcapitalização. 
2. Formas de custear investimentos empresariais e consequências fiscais

Uma das consequências do processo de globalização e formação de grupos econômicos descrito no capítulo anterior é a multiplicidade de alternativas quanto à estrutura de capital a ser adotada, visto que os grupos se tornaram complexos e o mercado passou a oferecer, ao longo do tempo, cada vez mais opções de estruturas para o financiamento de suas operações. ${ }^{32}$

Observam Roberto Quiroga Mosquera e Matheus Berthiolo Piconez que quando empresários decidem organizar suas atividades por meio de pessoa jurídica, eles devem decidir qual a melhor forma de obter capital e estruturar essa pessoa jurídica, pois, tipicamente, as pessoas jurídicas obtêm capital por meio de emissão de cotas ou ações, ou contraindo financiamentos e emitindo títulos representativos de dívidas. ${ }^{33}$

Neste sentido, pode-se afirmar de maneira resumida que ao avaliar estruturas de financiamento que lhes são disponíveis, as empresas podem optar primariamente entre duas formas de capitalização, mediante: (i) aporte de capital propriamente dito por parte dos sócios, ou (ii) endividamento contraído com os próprios sócios ou com terceiros não relacionados. $^{34}$

Buscando diferenciar as duas formas de capitalização, afirma Mariana Miranda Lima que o financiamento com origem no capital próprio possui, regra geral, duas principiais características: a indeterminação do prazo de concessão do financiamento e a existência de remuneração atrelada aos resultados da empresa investida, sendo que esse tipo de financiamento pode se dar no momento inicial da constituição da sociedade, ou

\footnotetext{
32 Observamos que a discussão relativa às formas de custear os investimentos empresariais é complexa e inclui diversos fatores a serem considerados. Por seu turno, tendo em vista o escopo do presente trabalho, restringiremos os comentários à análise dos elementos capital e empréstimos, bem como as suas conseqüências fiscais.

${ }^{33}$ MOSQUERA, Roberto Quiroga e PICONEZ, Matheus Berthiolo. "Tratamento Tributário dos Instrumentos Financeiros Híbridos”. In: MOSQUERA, Roberto Quiroga e LOPES, Alexsandro Broedel. (Coord.). Controvérsias jurídico-contábeis (aproximações e distanciamentos). $2^{\circ}$ Vol. São Paulo: Dialética, 2011, p. 233.

${ }^{34}$ GUZMAN, Antonio Carlos Marchetti e PENIDO, Tatiana Morais. "As Regras de Subcapitalização e sua Aplicação no Ordenamento Jurídico Brasileiro”. In: JUNIOR, Pedro Luciano Marrey et al. Sinopse Tributária 2010-2011. São Paulo: Impressão Régia, 2010, p. 73.
} 
mesmo em momento superveniente, por meio de aumento de capital social ou retenção autorizada de lucros passíveis de tributação. ${ }^{35}$

Por seu turno, os financiamentos realizados por meio de capital de terceiros são concedidos, regra geral, por prazo e remuneração determinados no momento da sua concessão à sociedade beneficiária e, em sua maioria, são financiamentos realizados após a constituição da sociedade, destinados a assegurar o incremento ou manutenção das suas atividades. $^{36}$

Considerando as opções disponíveis para o financiamento das atividades a serem desempenhadas e operações a serem desenvolvidas, se utilizando de capitais próprios dos sócios, mediante capitalização, ou se utilizando de capitais de terceiros, mediante endividamento, devem os empresários tomar em consideração uma pluralidade de fatores relevantes para o caso concreto, como a natureza da atividade, a fase em que o empreendimento se encontra e o custo comparativo dos capitais. ${ }^{37}$

Ante a pluralidade de variáveis envolvidas na escolha, surge uma questão bastante relevante: existe proporção ideal entre capital dos sócios e capital de terceiros?

Tentando encontrar resposta a essa questão, José Edson Lara e José Marcos Carvalho Mesquita analisaram o desempenho de empresas brasileiras no período pós-plano real vis-à-vis a estrutura de capital adotada e afirmam que a discussão sobre a adequada estrutura de capital é bastante complexa e envolve fatores como risco do negócio, lucratividade e taxas de retorno. Dentre esta infinidade de fatores considerados nas discussões, a tributação é citada pelos autores como sendo um dos fatores mais relevantes. $^{38}$

\footnotetext{
${ }^{35}$ LIMA, Mariana Miranda. A natureza jurídica dos juros sobre o capital próprio e as convenções para evitar a dupla tributação. 2009. Dissertação (Mestrado em Direito) - Faculdade de Direito, Universidade de São Paulo, São Paulo, 2009, p. 26-27.

${ }^{36}$ LIMA, Mariana Miranda. Ob. Cit., p. 27.

${ }^{37}$ XAVIER, Alberto. Direito Tributário Internacional do Brasil. $7^{\mathrm{a}}$ ed. Rio de Janeiro: Forense, 2010, p. 346.

${ }^{38}$ LARA, José Edson e MESQUITA, José Marcos Carvalho. Estrutura de Capital e Rentabilidade: análise do desempenho de empresas Brasileiras no período pós Plano Real in Revista Contabilidade Vista e Revista. v. 19, n. 2.Belo Horizonte: Universidade Federal de Minas Gerais, 2008, p. 15-33.
} 
Alberto Xavier segue linha semelhante e observa que entre os fatores de decisão:

podem também influenciar a decisão os ônus fiscais incidentes sobre as modalidades alternativas de financiamento, especialmente em sistemas jurídicos em que os juros têm um tratamento tributário menos oneroso do que os dividendos, considerado o efeito combinado da dedução do imposto sobre o lucro da pessoa pagadora (existente nos juros e não nos dividendos) com os tributos incidentes na fonte e na pessoa jurídica receptora. ${ }^{39}$

A questão tributária se mostra tão relevante a ponto de numerosos estudos empíricos terem examinado o papel dos tributos nas decisões das corporações, tais como escolha organizacional, decisões de investimentos, endividamentos, política de dividendos, atividades de fusões e aquisições e escolhas contábeis. ${ }^{40}$

Os comentários acima indicam que a decisão relativa à estrutura de capital pode influenciar de maneira relevante o sucesso ou insucesso de determinado negócio e, neste ponto, os respectivos reflexos fiscais são de extrema relevância para essa definição.

Desta forma, considerando que esta decisão (capital x empréstimo), bem como as conseqüências fiscais desta escolha, são vitais para o desenvolvimento do tema proposto, passaremos a tratar dessas questões nos itens seguintes.

\subsection{Capital}

Conforme mencionamos acima, uma das formas de capitalização é o aporte de capital propriamente dito, por parte dos sócios.

Nos dizeres de Nilton Latorraca, o capital é a expressão monetária da contribuição trazida pelos sócios para a formação do acervo indispensável à realização dos objetivos sociais, sendo que essa contribuição compreenderá dinheiro ou qualquer espécie de bens, móveis ou imóveis, corpóreos ou incorpóreos, suscetíveis de avaliação em dinheiro, sendo representado por ações ou quotas. ${ }^{41}$

\footnotetext{
${ }^{39}$ XAVIER, Alberto. Ob. Cit., p. 346.

${ }^{40}$ POHLMANN, Marcelo Coletto e IUDÍCIBUS, Sérgio de. Tributação e política tributária: uma abordagem interdisciplinar. São Paulo: Atlas, 2006, p. 78.

${ }^{41}$ LATORRACA, Nilton. Direito Tributário - Imposto de Renda das Empresas. São Paulo: Atlas, 1998, p. 582.
} 
Desta forma, pode-se entender o capital como a medida da contribuição dos sócios para a sociedade, onde estes transferem do seu patrimônio ao da pessoa jurídica, a propriedade de dinheiro, bem ou crédito, recebendo em troca ações (ou quotas) emitidas pela sociedade, em valor correspondente. ${ }^{42}$

Tendo em vista que os sócios decidem transferir parte do seu patrimônio ao da pessoa jurídica para a formação do capital desta, é de se esperar que, da mesma maneira que qualquer investimento no mercado financeiro ou de capitais, os sócios / acionistas visam retorno sobre o capital investido, seja por meio da valorização da companhia para posterior venda, seja por meio de remuneração do capital investido.

Presentemente, as duas formas mais comuns de remuneração do capital são dividendos e juros sobre capital próprio, sendo que estas remunerações podem ou não trazer conseqüências fiscais.

Considerando a estrutura adotada para o desenvolvimento do presente trabalho, discorremos neste capítulo sobre as conseqüências fiscais dos dividendos e, em item específico, trataremos dos juros sobre capital próprio.

\subsubsection{Conseqüências fiscais dos dividendos}

O capital investido pelos sócios ou acionistas poderá ser remunerado por meio de dividendos, correspondentes à destinação do lucro do exercício (ou de lucros acumulados em anos anteriores e ainda não distribuídos) proporcional (ou desproporcional) a participação dos acionistas / sócios.

Nesse sentido, tem-se por lucros e dividendos os rendimentos auferidos por sócios ou acionistas (pessoas físicas ou jurídicas) em razão de participação societária detida em determinada sociedade. ${ }^{43}$

\footnotetext{
${ }^{42}$ COELHO, Fábio Ulhoa. Curso de Direito Comercial. Volume 2. 14º Ed. São Paulo: Saraiva, 2010, p. 162.

${ }^{43}$ MIFANO, Flavio e ABREU, José Mauricio Carvalho. "A isenção ao imposto sobre a renda no repasse de dividendos por fundos de investimento". In: JUNIOR, Pedro Luciano Marrey et al. Sinopse Tributária 20102011. São Paulo: Impressão Régia, 2010, p. 90.
} 
Tratando das características dos dividendos no âmbito do direito societário, Roberto Quiroga Mosquera e Matheus Berthiolo Piconez listam 4 características dos dividendos:

a) são rendimentos pagos de forma variável ou fixa, conforme deliberação da assembleia;

b) são rendimentos juridicamente incertos quanto à possibilidade de pagamento, uma vez que dependem da existência de lucros sociais ou reserva de capitais;

c) decorrem de uma operação de participação societária e;

d) ainda que existam reservas de capital previamente ao lançamento das ações ou em data posterior à emissão, o pagamento de dividendos aos acionistas será incerto, uma vez que os prejuízos acumulados poderão consumir as respectivas reservas. ${ }^{44}$

Relativamente às consequências fiscais, observamos que o tratamento tributário dos dividendos foi alterado algumas vezes ao longo do tempo no ordenamento jurídico brasileiro, porém desde 1996 os dividendos passaram a ser neutros do ponto de vista tributário, visto que não se sujeitam a qualquer retenção na fonte e não constituem receita tributável para quem recebe ou despesa dedutível para quem paga.

Neste sentido, o art. 10 da Lei $n^{\circ}$ 9.249/95 veio estabelecer que os lucros e dividendos calculados com base nos resultados apurados a partir do mês de janeiro de 1996, pagos ou creditados pelas pessoas jurídicas tributadas com base no lucro real, presumido ou arbitrado, não estão sujeitos à incidência do imposto de renda na fonte, nem integram a base de cálculo do imposto de renda do beneficiário, seja pessoa física ou jurídica, seja domiciliado no País ou no Exterior.

Alberto Xavier registra que com a adoção deste regime, o Direito Brasileiro eliminou radicalmente a dupla tributação econômica dos lucros, submetendo-os exclusivamente à tributação na pessoa jurídica que os produziu, sem que ocorra nova incidência em razão da sua distribuição aos sócios. Como consequência, tornou as holdings brasileiras absolutamente transparentes, pois não só os dividendos não integram o lucro

\footnotetext{
${ }^{44}$ MOSQUERA, Roberto Quiroga e PICONEZ, Matheus Berthiolo. "Tratamento Tributário dos Instrumentos Financeiros Híbridos”. In: MOSQUERA, Roberto Quiroga e LOPES, Alexsandro Broedel. (Coord.). Ob. Cit. (nota 33), p. 246.
} 
real, como as distribuições ou redistribuições sucessivas não sofrem qualquer retenção na fonte. $^{45}$

Em que pese concordarmos parcialmente com o comentário de Alberto Xavier, na medida em que as holdings brasileiras não são absolutamente transparentes, pois eventual remuneração aos acionistas via os juros sobre o capital próprio (que trataremos em capítulo específico) se submeteriam, atualmente, a tributação das contribuições para o PIS e a COFINS, é certo que a medida estabelecida no final de 1995, com vigência a partir de 1996 representou grande avanço para eliminação de dupla tributação dos lucros aferidos pelas sociedades.

Nesta mesma esteira, observam Flavio Mifano e José Maurício Carvalho Abreu que o legislador ordinário, ao exercer sua competência tributária (de forma impositivanegativa), pretendeu que os lucros e dividendos distribuídos aos sócios ou acionistas ficassem isentos de tributação pelo Imposto de Renda, visando evitar aquilo que a literatura internacional convencionou chamar de double level of taxation, desta forma, os rendimentos já tributados em uma sociedade não são novamente onerados quando de sua percepção pelo titular da participação societária que deu causa ao pagamento, ou seja, o próprio sócio ou acionista. ${ }^{46}$

Complementa Alberto Xavier que a pureza lógica do sistema foi ao ponto de eliminar a retenção na fonte na distribuição de lucros a residentes no exterior, eliminando assim a discriminação (embora legítima) de tratamento fiscal entre residentes e não residentes, criando um forte atrativo ao investimento direto estrangeiro no país, dotado agora de substancial vantagem comparativa relativamente a outros países importadores de capital. $^{47}$

Ana Claudia Akie Utumi vai além ao mencionar:

adicionalmente, na medida em que as filiais, sucursais ou agências, localizadas no Brasil, de empresas estrangeiras são equiparadas a pessoa jurídica para fins de tributação - e portanto,

\footnotetext{
${ }^{45}$ XAVIER, Alberto. Ob. Cit. p. 485.

${ }^{46}$ MIFANO, Flavio e ABREU, José Mauricio Carvalho. "A isenção ao imposto sobre a renda no repasse de dividendos por fundos de investimento". In: JUNIOR, Pedro Luciano Marrey et al. Ob. Cit., p. 91.

${ }^{47}$ XAVIER, Alberto. Ob. Cit. p. 485.
} 
sujeitam-se à tributação com base no lucro real, presumido ou arbitrado - os seus resultados, quando transferidos para as respectivas matrizes, são albergados pela isenção em comento. ${ }^{48}$

A autora conclui o raciocínio ao afirmar que esta isenção também se aplica aos resultados de estabelecimento permanente mantidos no Brasil por empresas não-residentes, de acordo com o parágrafo único do art. 694 do Regulamento do Imposto de Renda (Decreto 3.000/99). ${ }^{49}$

Os comentários de Ana Cláudia Utumi reafirmam a linha de raciocínio anteriormente explorada e acrescenta elementos que demonstram a abrangência da norma estabelecida em 1995 e que vige até hoje.

\subsection{Empréstimos}

Alternativamente ao aporte de capital propriamente dito por parte dos sócios, também é possível utilizar, como forma de capitalização, o endividamento contraído com os próprios sócios ou com terceiros não relacionados.

Podemos entender o endividamento, como um contrato de mútuo celebrado entre a pessoa jurídica tomadora dos recursos de um lado e os próprios sócios ou terceiros de outro lado.

Neste sentido, esclarece Eduardo Salomão Neto:

o mútuo é a operação bancária básica, mas é também utilizado fora da atividade financeira. Por tal razão, não é frequentemente considerado um contrato exclusivamente bancário. No direito brasileiro, o mútuo é legislativamente tratado como contrato de empréstimo, ao lado do comodato, de acordo com os artigos 586 a 592 do Código Civil de 2002. ${ }^{50}$

O autor complementa o raciocínio afirmando que o mútuo é contrato de empréstimo de coisa fungível e trata-se de um contrato real, isto é, o contrato só se aperfeiçoa pela

${ }^{48}$ UTUMI, Ana Claudia Akie. O regime tributário brasileiro do imposto sobre a renda de não-residente - A fonte como critério de conexão. Tese (Doutorado em Direito) - Faculdade de Direito, Universidade de São Paulo, São Paulo, 2005, p. 175.

${ }^{49}$ UTUMI, Ana Claudia Akie. Ob. Cit., p. 175.

${ }^{50}$ SALOMÃO Neto, Eduardo. Direito Bancário. São Paulo: Atlas, 2005, p. 179. 
entrega pelo mutuante da coisa emprestada ao mutuário, sendo que, sem tal entrega, não há o que se falar na existência de um contrato de mútuo. ${ }^{51}$

Desta forma, o mero acordo de vontade entre as partes sobre o empréstimo não é suficiente para a formação de um contrato de mútuo. Tal acordo é apenas uma promessa, que recebe o nome de abertura de crédito na atividade bancária e tem o tratamento de contrato preliminar, nos termos dos artigos 462 a 466 do Código Civil de $2002 .^{52}$

Tomando por base os comentários acima, no contrato de mútuo, cujo objeto é dinheiro, para que ocorra a formação do contrato de mútuo, deve haver a entrega efetiva de recursos financeiros; ou seja, no caso em análise, os sócios ou terceiros não relacionados devem efetivamente entregar recursos financeiros para a pessoa jurídica tomadora para que ocorra a formação do contrato de mútuo ou empréstimo (utilizados como figuras equivalentes nesta análise).

Da mesma maneira que o capital investido pelos sócios ou acionistas pressupõe uma remuneração, o mútuo também pressupõe a contrapartida de remuneração e, neste caso, a remuneração do capital empregado é feita por meio de juros, conforme estabelece o artigo 591 do Código Civil de 2002 que assim dispõe: “art. 591 - destinando-se o mútuo a fim econômico, presumem-se devidos os juros, os quais, sob pena de redução, não poderão exceder a taxa a que se refere o art. 406, permitida a capitalização anual”.

Referido art. 406 determina: "art. 406 - quando os juros moratórios não forem convencionados, ou o forem sem taxa estipulada, ou quando provierem de determinação de lei, serão fixados segundo a taxa que estiver em vigor para a mora do pagamento de impostos devidos à Fazenda Nacional".

Definido o conceito de mútuo, bem como a sua forma de remuneração, assim entendido os juros, passamos a discorrer sobre o limite dos juros nos contratos de empréstimos e posteriormente sobre as consequências fiscais destes.

${ }^{51}$ SALOMÃO Neto, Eduardo. Ob. Cit. p. 179.

${ }^{52}$ SALOMÃO Neto, Eduardo. Ob. Cit. p. 180. 
2.2.1 Limite dos juros nos contratos de empréstimos no direito comparado

Em amplo estudo sobre os juros, ao tratar dos limites das taxas de juros no direito comparado e no direito brasileiro, registra Luiz Antonio Scavone Junior que alguns sistemas indicam as taxas de juros apenas como referência, permitindo a pactuação de taxas superiores, como é caso do Código Civil italiano, que estabelece no art. 1284 a taxa de $5 \%$ ao ano, bem como o Código Civil alemão determina a taxa de $4 \%$ e ainda o Código Civil peruano estipula taxa de 5\% ao ano (arts. 1324 e 1325), sendo todas essas taxas apenas para referência. ${ }^{53}$

Por outro lado, é possível encontrar sistemas que fixam as taxas de juros de forma cogente, o que faz Portugal nos arts. 559 e 1.146 do Código Civil, limitando as taxas de juros compensatórios a 3\% e 5\% ao ano acima da taxa legal e as taxas de juros moratórios a $7 \%$ e $9 \%$ acima da taxa legal, conforme haja ou não garantia real. ${ }^{54}$

Registra ainda o autor que outros sistemas não fixam limites para as taxas de juros, mas permitem a redução das taxas pactuadas no caso de usura, subjetivamente considerada, sendo esse o caso da Argentina, França (Decreto-lei de 08.08.1935) e Espanha (Lei de 23.07.1908). ${ }^{55}$

Por fim, há outros sistemas onde não há qualquer limitação de taxas como, por exemplo, na Suíça, inferência que se extrai do art. 314 do Código Federal Suíço das obrigações. $^{56}$

$\mathrm{O}$ autor não emite nenhum juízo de valor quanto ao melhor sistema ou eventualmente o sistema mais justo, não sendo também esse o foco do presente trabalho, por outro lado, nos parece que o sistema que apenas indica taxas referencia valoriza a liberdade negocial e propicia a utilização de taxas de mercado mais facilmente. Em que pese os benefícios que nos parecem serem proporcionados por esse sistema, resta claro que a sua compatibilidade com o sistema jurídico vigente deve ser considerada.

\footnotetext{
${ }^{53}$ SCAVONE Junior, Luiz Antonio. Ob. Cit., p. 70. SCAVONE Junior, Luiz Antonio. Juros no direito brasileiro. $3^{\circ}$ ed. ver., atual. e amp. São Paulo: Revista dos Tribunais, 2003, p. 70.

${ }^{54}$ SCAVONE Junior, Luiz Antonio. Ob. Cit., p. 70.

${ }^{55}$ SCAVONE Junior, Luiz Antonio. Ob. Cit., p. 70.

${ }^{56}$ SCAVONE Junior, Luiz Antonio. Ob. Cit., p. 70.
} 
Visto brevemente como o direito comparado trata o limite de juros nos contratos de empréstimos, passamos a analisar como a questão é tratada no Brasil.

2.2.2 Limite dos juros nos contratos de empréstimos no direito brasileiro

Como se observa nos artigos 406 e 591 do Código Civil Brasileiro, anteriormente referidos, pode-se afirmar ser pacífico que o Brasil optou por seguir os sistemas que fixam as taxas de juros de forma cogente, estabelecendo normas que limitam as taxas de juros que podem ser convencionadas nos contratos.

Por outro lado, o limite vigente dos juros nos contratos de empréstimos ou mútuos é tema controverso, como veremos a seguir.

Em 07 de abril de 1933 foi publicado o Decreto $n^{\circ}$ 22.626, conhecido como Lei da Usura, que determinava em seu artigo $1^{\circ}$ que era vedado estipular, em qualquer contrato, taxa de juros superiores ao dobro da taxa legal. Desta forma, como o art. 1062 do código civil de 1916 (vigente à época da publicação do referido decreto) determinava que a taxa de juros moratórios era de $6 \%$ ao ano, se entendia que a taxa máxima de juros seria de $12 \%$ ao ano.

Entretanto, o código civil de 1916 foi substituído pelo código civil de 2002 (Lei no 10.406) e o art. 406 do novo código civil determinou que quando os juros moratórios não forem convencionados ou não for estipulada a taxa aplicável, essa será fixada segundo a taxa em vigor para a mora do pagamento de impostos devidos à Fazenda Nacional, sendo essa taxa, presentemente, a taxa SELIC.

Complementa ainda o art. 591 do referido diploma legal, que o mútuo destinado a fins econômicos, não poderá definir taxa superior à definida no art. 406 (SELIC), sendo permitida a capitalização anual.

Desta forma, para aqueles que entendem que a lei da usura não foi revogada com a publicação do novo código civil (de 2002), é possível estipular em quaisquer contratos, 
taxas de juros até o limite do dobro da taxa legal, sendo esta definida, presentemente, pelo art. 406 do Código Civil como sendo a taxa SELIC. Neste sentido, os juros máximos seriam equivalentes ao dobro da taxa Selic.

Por seu turno, aqueles que entendem que a Lei da Usura foi revogada pelo código civil de 2002, aplicam como fundamento para o limite vigente de juros o art. 591 do Código Civil (combinado com o art. 406 do mesmo diploma legal) que determina que no mútuo destinado a fins econômicos, os juros não podem exceder a taxa SELIC.

Há ainda outra linha de entendimento possível, adotada por Luiz Antonio Scavone Junior, que entende que em qualquer caso, a taxa do Código Civil de 2002 está fixada em $1 \%$ ao mês, nos termos do art. $161, \S 1^{\circ}$ do Código Tributário Nacional - CTN e no art. $5^{\circ}$ do Decreto $22.626 / 33 .^{57}$

Essa linha de raciocínio se pauta no fato do art. $161, \S 1^{\circ}$ do CTN, materialmente lei complementar $^{58}$, determinar que a taxa para pagamento de tributos em mora é de $1 \%$ ao mês, ou seja, $12 \%$ ao ano, sendo essa a taxa legal de juros moratórios e que, mesmo diante da publicação do Código Civil de 2002, a Lei de Usura continua válida, vigente e eficaz, pois lei genérica posterior não regova lei anterior especial. ${ }^{59}$

Conjugando-se os comentários acima, observamos três conclusões possíveis para definir o limite de juros nos contratos de empréstimos no direito brasileiro: i) o dobro da taxa SELIC; ii) a taxa SELIC e; iii) $12 \%$ ao ano.

Observamos ainda discussão adicional relativa à limitação do estabelecimento dos juros nos contratos bancários, sendo relevante observar que a reiterada jurisprudência do Superior Tribunal de Justiça - STJ segue na linha que não há limitação de juros aos contratos celebrados com instituições integrantes do Sistema Financeiro Nacional. ${ }^{60}$

\footnotetext{
${ }^{57}$ SCAVONE Junior, Luiz Antonio. Ob. Cit., p. 196.

${ }^{58}$ Observa o autor que a taxa SELIC, instituída por leis ordinárias (Leis 9.065/95 e 9.779/99), não pode ser aplica em detrimento do art. 161 do CTN em razão do princípio da hierarquia, pois o CTN foi recepcionado pela Constituição Federal de 1988 como lei materialmente complementar (art. 34 do ADCT).

${ }^{59}$ SCAVONE Junior, Luiz Antonio. Ob. Cit., p. 196.

${ }^{60}$ Vide AgRg no RECURSO ESPECIAL No 920.437 - RS (2007/0016604-4)
} 
Registra-se a discussão acerca do limite de juros a ser exigido nos contratos de empréstimo apenas para demonstrar a linha adotada no Brasil, no sentido de definir uma taxa máxima a ser exigida neste tipo de contrato, sendo certo que os contratos celebrados por pessoas físicas ou jurídicas brasileiras deverão observar determinado limite de juros, sendo o limite definido de acordo com a linha de entendimento adotada (i) o dobro da taxa SELIC; ii) a taxa SELIC ou iii) $12 \%$ ao ano).

Registrada a discussão e possíveis conclusões, passa-se a analisar as consequências fiscais dos juros nos contratos de empréstimos, tendo em mente que os contratantes não possuem livre arbítrio para definição da taxa de juros, devendo respeitar o limite imposto pela legislação civil e tributária, conforme registramos acima.

2.2.3 Conseqüências fiscais dos juros nos contratos de empréstimos celebrados por pessoas jurídicas $^{61}$

Pode-se afirmar que a principal conseqüência fiscal dos juros pagos em decorrência de contratos de empréstimos celebrados por pessoas jurídicas se dá no âmbito do imposto sobre a renda, na medida em que os juros podem ser dedutíveis ou não, ou em outras palavras, podem reduzir a base de cálculo do imposto de renda da pessoa jurídica ou não, a depender de determinadas condições, conforme veremos a seguir.

Em extenso trabalho sobre os fundamentos do imposto de renda, Ricardo Mariz de Oliveira analisa a questão da dedutibilidade das despesas operacionais e não operacionais e afirma existirem quatro regras gerais básicas para assegurar a dedutibilidade de qualquer despesa na base de cálculo do imposto de renda: (i) despesas não devem ser custos; (ii) despesas devem ser necessárias; (iii) despesas devem ser comprovadas e escrituradas e (iv) despesas devem ser debitadas no período-base competente. ${ }^{62}$

Com relação à primeira regra (despesas não devem ser custos), esclarece o autor que a distinção entre custos e despesas é estabelecida a partir do emprego dos recursos

\footnotetext{
${ }^{61}$ Tendo em vista que as conseqüências fiscais dos juros nos contratos de empréstimos celebrados por pessoas físicas não são relevantes para o objeto do presente estudo, abordaremos apenas as conseqüências fiscais nos contratos celebrados por pessoas jurídicas.

${ }^{62}$ OLIVEIRA, Ricardo Mariz de. Fundamentos do Imposto de Renda. São Paulo: Quartier Latin, 2008, p. 685 a 723.
} 
despendidos (ou a serem despendidos) pela pessoa jurídica. Quando emprega os recursos do seu ativo ou incorre em dívidas para aquisição de um bem ou direito, tem um custo. Por outro lado, quando emprega recursos ou incorre em dívida para pagar um encargo que não representa algo que ainda remanesça no seu ativo, incorre em uma despesa. ${ }^{63}$

Desta forma, caso o empréstimo tenha sido destinado à aquisição de um bem ou direito, os juros incorridos seriam considerados custos e desta forma, dedutíveis na apuração do imposto de renda da pessoa jurídica por esse motivo. Por outro lado, caso tenha sido dada outra destinação aos recursos obtidos por meio empréstimo, os juros incorridos terão a natureza de despesa e deverão atender as três regras adicionais para serem considerados dedutíveis na apuração do imposto.

A segunda regra (despesas devem ser necessárias) é a "regra de ouro", que se coloca no centro da dedutibilidade das despesas, pois se trata de regra aplicável a todas as despesas para as quais não haja uma norma específica sobre dedutibilidade. O conceito de despesa necessária é, correntemente, determinado pelo art. 47 da Lei $\mathrm{n}^{\circ}$ 4.506, de 1964, dispositivo este reproduzido no art. 299 do Regulamento do Imposto de Renda, sendo consideradas necessárias as despesas pagas ou incorridas para a realização das transações ou operações exigidas pela atividade da empresa. ${ }^{64}$

Por seu turno, para determinados tipos ou espécies de despesas há normas especiais que podem: (a) proibir a dedutibilidade de uma determinada despesa; (b) limitar o valor da sua dedutibilidade; (c) condicionar a sua dedutibilidade ao cumprimento de algum requisito, o qual pode ser uma determinada forma de comprovação; (d) determinar a dedução em período-base diferente no qual tenha sido contabilizada, ou ainda (e) atribuirlhe algum tratamento fiscal específico (como certas deduções em dobro, a título de incentivo fiscal).

Especificamente com relação aos juros, esclarece o jurista que o pagamento de juros só é necessário para a empresa pela carência de recursos próprios ou porque interessa à empresa contrair empréstimos por razões de crédito ou de política financeira. Mas em

${ }^{63}$ OLIVEIRA, Ricardo Mariz de. Ob. Cit. p. 685 a 723.

${ }^{64}$ OLIVEIRA, Ricardo Mariz de. Ob. Cit. p. 685 a 723. 
qualquer dessas hipóteses, a despesa é sempre necessária porque decorre da atividade da empresa. $^{65}$

Relativamente à terceira regra (despesas devem ser comprovadas e escrituradas), observa-se que a lei exige que as despesas sejam registradas contabilmente e devem ser devidamente identificadas através de requisitos formais, tais como: faturas, notas fiscais, recibos, etc.; bem como requisitos intrínsecos, tais como: identificação da operação, das quantidades, dos valores, das partes envolvidas, etc. ${ }^{66}$

Conseqüentemente, para atendimento desta regra, o empréstimo deve ser formalizado por meio de contrato (ou documento equivalente), especificando-se o valor do empréstimo, as partes envolvidas, o prazo, os juros devidos, a forma de pagamento, etc.

Por fim, a última regra geral básica para dedutibilidade das despesas se refere ao período de competência. Segundo essa regra, as despesas devem ser deduzidas no lucro real no período-base competente, isto é, naquele em que jurídica ou economicamente elas se tornarem devidas ou em que possam ser excluídas do lucro líquido para determinação do lucro real segundo a lei tributária. ${ }^{67}$

Desta forma, o registro contábil, bem como a dedução da base de cálculo do imposto de renda, deve seguir o período de competência definido no contrato para o pagamento dos juros.

As quatro regras gerais básicas definidas por Ricardo Mariz de Oliveira são plenamente aplicáveis aos contratos de empréstimos, devendo sempre ser observadas quando da análise das conseqüências fiscais dos juros deles decorrentes. ${ }^{68}$

\footnotetext{
${ }^{65}$ OLIVEIRA, Ricardo Mariz de. Ob. Cit. p. 685 a 723.

${ }^{66}$ OLIVEIRA, Ricardo Mariz de. Ob. Cit. p. 685 a 723.

${ }^{67}$ OLIVEIRA, Ricardo Mariz de. Ob. Cit. p. 685 a 723.

${ }^{68}$ Especificamente com relação aos juros pagos a pessoas vinculadas no exterior, quando decorrentes de contratos de mútuo (no caso de um contrato de empréstimo entre filial brasileira e matriz no exterior, por exemplo), existe regra adicional a ser observada, definida no artigo 22 da Lei 9.430/96, decorrente das regras que regulam o preço de transferência, entretanto, por não ser objeto do presente trabalho, não às abordaremos.
} 
Desta forma, de maneira resumida, esses eram os únicos requisitos a serem observados para dedução dos juros na base de cálculo do imposto de renda e da contribuição social sobre o lucro até a publicação das normas que versam sobre a subcapitalização, que passam a ser tratadas de maneira detalhada no próximo capítulo. 
3. Aspectos gerais da subcapitalização

Conforme comentamos no capítulo anterior, ao avaliar as estruturas de financiamento que lhes são disponíveis, as empresas podem optar por duas formas de capitalização, mediante: i) aporte de capital propriamente dito por parte dos sócios, também conhecido por equity ou ii) endividamento contraído com os próprios sócios ou terceiros não relacionados, também conhecido por debit.

No primeiro caso, a remuneração do acionista é feita, em grande parte dos casos, via dividendos; por outro lado, no segundo caso, a remuneração é feita, em geral, mediante pagamento de juros.

Também mencionados no capítulo 2 que, considerando as opções disponíveis para o financiamento das atividades a serem desempenhadas e operações a serem desenvolvidas, via equity ou debit, devem os empresários tomar em consideração uma pluralidade de fatores relevantes para o caso concreto, como a natureza da atividade, a fase em que o empreendimento se encontra, o custo comparativo dos capitais, etc.; sendo que o fator tributário mostra-se como um dos mais relevantes para essa análise.

Nesse sentido, registram Antônio Carlos Marchetti Guzman e Tatiana Morais Penido que ainda que o processo decisório pertinente à escolha entre financiamento via aporte de capital ou endividamento leve em consideração outros fatores que não puramente conexos a potencial economia tributária, a opção pelo financiamento via endividamento pode revelar-se especialmente vantajosa, tendo em vista a possibilidade de dedução dos juros do cálculo do imposto de renda da pessoa jurídica e da contribuição social sobre o lucro líquido, ao passo que despesas com pagamento de dividendos são neutras do ponto de vista tributário. ${ }^{69}$

Desta forma, considerando as opções disponíveis e eventuais vantagens associadas ao financiamento via endividamento com os próprios acionistas/sócios ou com terceiros, podem os sócios ou acionistas optarem por grandes volumes de endividamento (debit).

${ }^{69}$ GUZMAN, Antonio Carlos Marchetti e PENIDO, Tatiana Morais. "As Regras de Subcapitalização e sua Aplicação no Ordenamento Jurídico Brasileiro”. In: JUNIOR, Pedro Luciano Marrey et al. Ob. Cit., p. 73. 
Tendo em vista a possibilidade de se obter grandes volumes de empréstimos, eventual endividamento excessivo (segundo critérios que serão descritos a seguir) pode caracterizar o que comumente se chama de subcapitalização.

Nos estudos do International Bureau of Fiscal Documentation - IBFD é possível encontrar farto material sobre a subcapitalização, sendo relevante citar uma pesquisa conduzida por funcionários da empresa de auditoria KPMG do Reino Unido, intitulado Financing: A global survey of thin capitalization and transfer pricing rules in 35 selected countries, que seguiu a mesma linha dos comentários acima ao afirmar que o problema da subcapitalização sob uma perspectiva fiscal está relacionado ao retorno sobre o equitycapital e o debit-capital, pois são tratados diferentemente para fins fiscais.

Afirma o estudo que a remuneração dos acionistas / sócios nos equity-investments não é dedutível dos tributos corporativos (para a companhia que paga), caracterizando, na grande maioria dos casos, distribuição de lucros ao invés de despesas operacionais. Por outro lado, a remuneração de quem empresta $(d e b t)$ - em geral sob a forma de juros - é dedutível sob perspectiva dos tributos corporativos de quem paga a remuneração. ${ }^{70}$

Como consequência do tratamento tributário acima descrito, resta claro que as companhias em geral, buscando maior eficiência fiscal, podem utilizar operações de debt para situações que normalmente se esperaria uma operação de equity, ou ainda, propicia a criação de instrumentos de equity e que, devido a alguma particularidade da legislação local são tratados como debt e, desta forma, obtém-se a vantagem fiscal desejada, mesmo com instrumentos conceitualmente de equity.

Considerando a diferença do tratamento, o estudo observa ainda que outra consequência possível é o endividamento excessivo e conclui que o efeito de custear uma companhia ou várias companhias com empréstimos excessivos - sejam eles provenientes de companhias vinculadas / ligadas ou em empréstimos garantidos por estas - é, potencialmente, a dedução excessiva de juros. ${ }^{71}$

\footnotetext{
${ }^{70}$ LUND, Henrik; KORSGAARD, Carina Marie e ALBERTSEN, Mathias. Financing: a global survey of thin capitalization and transfer pricing rules in 35 selected countries. International transfer pricing journal. Journals IBFD. Vol. 15, nº 6. Amsterdam, 2008, p. 283.

${ }^{71}$ LUND, Henrik; KORSGAARD, Carina Marie e ALBERTSEN, Mathias. Ob. Cit., p. 283.
} 
Neste sentido, legislações que regulam a subcapitalização procuram evitar a dedução excessiva de juros - dentre outras medidas - limitando a dedução de juros do tomador do empréstimo à condição de mercado. ${ }^{72}$

Considerando esse contexto, a subcapitalização é tolerada ou não para fins fiscais, dependendo da opção de cada país, sendo possível identificar países que optaram por não regular a matéria, tais como Luxemburgo, Porto Rico, Singapura, Suécia, Finlândia e Noruega e outros que estabeleceram legislação tendente à regular a matéria, tais como França, Reino Unido, China e, mais recentemente, o Brasil.

Stuart Webber, professor no Trinity Lutheran College em Washington e membro do Copenhagen Research Group on International Taxation, identifica vantagens na adoção de regras desenhadas para combater as estruturas de financiamento que levam a subcapitalização e afirma que estas são importantes para os grupos econômicos e para o governo. $^{73}$

Da perspectiva do governo, essas estruturas afetam tanto a receita tributária quanto a competitividade econômica do país. De outro lado, da perspectiva dos grupos econômicos, essas estruturas podem aumentar as despesas dedutíveis das empresas e, conseqüentemente, determinar onde os negócios serão conduzidos. ${ }^{74}$

Relativamente aos países que optaram regular a matéria, observamos a adoção majoritária de dois critérios diferentes: safe haven e arm's length, sendo possível identificar características próprias na legislação de cada país.

Considerando as diferentes opções registradas acima, passamos a analisar genericamente o safe haven e arm's length vis-à-vis as regras de subcapitalização e, posteriormente, trataremos das regras individuais de cada país selecionado para estudo.

\footnotetext{
${ }^{72}$ LUND, Henrik; KORSGAARD, Carina Marie e ALBERTSEN, Mathias. Ob. Cit., p. 283.

73 WEBBER, Stuart. Thin Capitalization and Interest Deduction Rules: A Worldwide Survey. Tax notes international - falls church. Vol. 60. $\mathrm{n}^{\circ}$ 9. 2010, p. 683.

${ }^{74}$ WEBBER, Stuart. Ob. Cit., p. 683.
} 
Em muitos países, uma companhia é qualificada como subcapitalizada, quando o seu capital é constituído por uma proporção maior de debt do que equity, produzindo o chamado endividamento excessivo; desta forma, as regras para desencorajar a subcapitalização exigem determinada proporção mínima entre o capital aportado pelos sócios e o endividamento total da empresa para permitir (ou não) a dedução de despesas de juros pagos em decorrência do endividamento (debt).

A proporção mínima entre equity e debt varia de um país para outro e, inclusive, em alguns países, varia de setor para setor.

Segundo esse critério, o endividamento excessivo supõe uma comparação entre um numerador (o endividamento ou debt) e um denominador (patrimônio líquido, capital próprio ou equity), de forma que se o razão ou coeficiente for superior à determinada proporção, será considerado "excessivo" ou, como diz a lei americana, haverá um excessive interest expense. ${ }^{75}$

Roberto Quiroga Mosquera e Rodrigo de Madureira Pará Diniz seguem a mesma linha e afirmam:

muito embora possam as sistemáticas de aplicação variar de acordo com a legislação praticada nos países e jurisdições que as adotam, as regras de subcapitalização prestam-se a regular, nos diferentes ordenamentos jurídicos, a proporção máxima permitida para composição de dívida e capital, para fins de apuração do Imposto sobre a Renda das pessoas jurídicas. ${ }^{76}$

A proporção máxima permitida para composição da dívida e capital acima referida, caracteriza uma regra de safe haven, conforme descrevemos no item 1.3.1.

\footnotetext{
${ }^{75}$ XAVIER, Alberto. Ob. Cit. p. 351.

${ }^{76}$ MOSQUERA, Roberto Quiroga e DINIZ, Rodrigo de Madureira Pará. “As regras de Subcapitalização no Direito Brasileiro - Questões Controversas”. In: ROCHA, Valdir de Oliveira (coord.). Grandes Questões Atuais do Direito Tributário. $15^{\circ}$ Vol. São Paulo: Dialética, 2011, p. 392.
} 
O safe haven tem grande importância para as regras de subcapitalização, a ponto do General Report de 1996 da International Fiscal Association - IFA dedicar um capítulo inteiro às safe haven rules (capítulo 5), tratando do tema detalhadamente.

Afirma o relatório que a determinação do safe haven gera segurança e clareza à lei, de maneira que tanto o acionista quanto a empresa subsidiária sabem exatamente até que nível de endividamento os juros ainda serão dedutíveis. ${ }^{77}$

Por outro lado, o relatório apresenta duas desvantagens da adoção de safe haven rules para as regras de subcapitalização:

a) internacionalmente, existem diferenças significativas entre os típicos níveis de endividamento das pessoas jurídicas, sendo possível citar como exemplo os Estados Unidos e Reino Unido que possuem nível médio de endividamento acima de $40 \%$, enquanto Japão e Alemanha apresentam endividamento próximo de $20 \%$ do capital.

Considerando essas diferenças, uma padronização internacional de safe haven, por exemplo, 3:1 (endividamento permitido até três vezes maior que o capital) poderia não se mostrar justo para todos os países, na medida em que geraria, em grande parte dos casos, despesas indedutíveis para as empresas americanas e inglesas e ao mesmo tempo, não geraria, na maior parte dos casos, despesas indedutíveis para empresas japonesas e alemãs.

b) O endividamento em cada país varia em proporção relevante, dependendo de sua indústria, sendo possível considerar o exemplo dos Estados Unidos referido acima, que tem em média um endividamento de $40 \%$, porém composto por diferentes tipos de indústrias e empresas e com diferentes níveis de endividamento.

No que tange as consequiências legais da não observância do safe haven, registra o relatório da IFA que em termos de legislação de subcapitalização, a conseqüência legal é a não dedutibilidade dos juros excedentes a proporção definida por essas regras, em outras

\footnotetext{
${ }^{77}$ INTERNATIONAL FISCAL ASSOCIATION - IFA. Ob. Cit. (nota 8), p. 111.
} 
palavras, não há penalização relativa à totalidade dos juros pagos a acionistas não residentes quando a proporção definida pelas safe haven rules não é observada, mas apenas do excedente a elas.

Analisando a evolução histórica das regras de subcapitalização, observou Stuart Webber que, em um primeiro estágio, a maioria das regras de subcapitalização estabelecia a existência do "safe harbour" (na proporção entre endividamento e capital) em uma tentativa de forçar as partes relacionadas ou vinculadas a aplicar condições normais de mercado em suas operações intra-grupo. ${ }^{78}$

Por seu turno, alguns países entenderam que era relativamente simples para as companhias reduzirem essa proporção por meio do aumento de capital até o limite necessário para o atendimento dos limites mínimos de capital vis-à-vis o valor do endividamento e, desta forma, parte dos países migrou para regras com um foco mais voltado a limitação direta de juros ou ainda, regra que buscavam a comparação com operações realizadas entre partes não relacionadas: eis que surgem as regras vinculadas ao princípio arm's length. $^{79}$

3.2 Arm's length e as regras de subcapitalização

Conforme referido acima, a subcapitalização, em determinados países, correlaciona o endividamento excessivo ao princípio "arm's length".

Interessante observar inicialmente que o relatório da IFA sobre subcapitalização, datado de 1996, registrou que nenhum dos relatórios recebidos dos países membros confiava somente no arm's length para evitar a subcapitalização, sendo o princípio sempre utilizado em conjugação com outros critérios tendentes a evitar a subcapitalização. ${ }^{80}$

Por outro lado, observou Stuart Weber, em 2009, que o Reino Unido começou limitando a proporção debit-to-equity e agora confia exclusivamente no arm's length, o

\footnotetext{
${ }^{78}$ WEBBER, Stuart. Ob. Cit., p. 687.

${ }^{79}$ WEBBER, Stuart. Ob. Cit., p. 688.

${ }^{80}$ INTERNATIONAL FISCAL ASSOCIATION - IFA. Ob. Cit. (nota 8), p. 103.
} 
que pode demonstrar uma evolução da aplicação do princípio no âmbito das regras de subcapitalização. ${ }^{81}$

Essa afirmação, contudo, deve ser realizada com cautela na medida em que essa mudança de padrão não se refletiu em todos os países que adotam regras tendentes a evitar a subcapitalização ou tendentes a limitar os juros pagos em empréstimos entre companhias ligadas/vinculadas.

Outra fonte importante de pesquisa são os estudos do IBFD, onde também encontramos diversas referências à aplicação do princípio arm's length nas regras de subcapitalização, como, por exemplo, um artigo dedicado especificamente a visão geral da aplicação do princípio às regras de subcapitalização, chamado An overview of arm's length approaches to thin capitalization.

Referido artigo, escrito por Luís Coronado, Patrick Cheung e Justin Kyte esclarece que a adoção do princípio arm's length busca reproduzir o processo de decisão que um credor adotaria para decidir se deve conceder ou não o empréstimo a determinada empresa, e caso decidisse por conceder o empréstimo, qual seria o montante e a taxa de juros a ser praticada. $^{82}$

Neste caso, a questão crucial a ser respondida é: um terceiro receberia um empréstimo em condições similares ao empréstimo concedido por determinada empresa à outra parte relacionada ou vinculada? ${ }^{83}$

Em que pese parecer possível uma resposta direta e objetiva a questão colocada acima, o que se observa na prática é que a resposta não é tão simples.

A concessão de um empréstimo entre empresas não vinculadas ou relacionadas envolve análise financeira detalhada sobre o potencial tomador do empréstimo, começando com uma consulta ao cadastro de inadimplentes (função desempenhada, atualmente, pela empresa Serasa no Brasil), passando pela verificação de ratings atribuídos por agências de

\footnotetext{
${ }^{81}$ WEBBER, Stuart. Ob. Cit., p. 688.

${ }^{82}$ CORONADO, Luis; CHEUNG, Patrick e Kyte, Justin. Ob. Cit.

${ }^{83}$ CORONADO, Luis; CHEUNG, Patrick e Kyte, Justin. Ob. Cit.
} 
classificação de risco, até a avaliação da sua capacidade de pagamento por meio da análise minuciosa dos últimos balanços publicados.

Quando o empréstimo a ser concedido tem como candidata empresa pertencente a determinado grupo econômico, a análise financeira é ainda mais rigorosa e leva em conta não apenas os dados financeiros da empresa potencialmente tomadora do crédito, mas também a análise de todo o grupo econômico, visto que pode haver operações entre as empresas integrantes do grupo, tendentes a melhorar o balanço da empresa tomadora do crédito, de maneira que esta obtenha crédito que normalmente não obteria se não houvesse referidas operações entre empresas do grupo.

Todos os elementos acima conjugados, na prática, dificultam a afirmação direta e peremptória que determinada operação entre empresas relacionadas ou vinculadas observou ou não o princípio arm's length, visto que as operações a serem utilizadas como parâmetro de comparação, assim entendidas as operações entre partes não relacionadas, possuem, atualmente, tamanha complexidade que em muitos casos não é possível realizar a analise de todos os elementos envolvidos na operação.

Realizada a análise da aplicação de regras de safe havens e do principio arm's length para as regras de subcapitalização, bem como eventuais deficiências de cada uma, passamos a análise da experiência internacional, buscando identificar qual o critério utilizado por cada um dos países escolhidos para estudo.

\subsection{Experiência em outros países}

Após as considerações iniciais sobre a subcapitalização, podemos avançar para a análise específica das regras que tratam do tema.

Por seu turno, como as regras que versam sobre a subcapitalização foram estabelecidas no Brasil recentemente, faz-se relevante verificar inicialmente a experiência em outros países, pois o tema é debatido na doutrina estrangeira há muito tempo e diversos países possuem legislação e doutrina bastante evoluída sobre o assunto. 
3.3.1 OCDE - Organização para a Cooperação e Desenvolvimento Econômico

Iniciamos a análise com os estudos da Organização para a Cooperação e Desenvolvimento Econômico- OCDE.

A história da OCDE remonta a 1947 quando da criação da então chamada Organização para a Cooperação da Economia Européia - OEEC. Referida entidade foi estabelecida com a finalidade de administrar o plano de financiamento dos Estados Unidos para a reconstrução do continente Europeu após a guerra, conhecido como Plano Marshall. ${ }^{84}$

Encorajados pelo sucesso da Organização, Canadá e Estados Unidos se juntaram aos membros da OEEC e assinaram uma nova convenção em 14 de dezembro de 1960, estabelecendo a Organização para a Cooperação e Desenvolvimento Econômico OCDE. $^{85}$

Após a formação da OCDE, outros países se juntaram ao grupo fundador, começando com o Japão em 1964 e hoje há 34 membros de todo o mundo. A principal finalidade da entidade é identificar problemas comuns, discuti-los e promover políticas para resolvê-los. ${ }^{86}$

Por seu turno, países não membros e que até pouco tempo atrás tinham menor relevância na economia mundial, tais como Brasil, China e Índia, passaram a influenciar a economia global e, em conjunto com outros países como Rússia, Indonésia e África do Sul, têm assento na mesa de discussões com os membros da OCDE e, juntos, representam cerca de $80 \%$ do comércio e investimento mundial, o que torna essa organização um dos centros de discussão da economia mundial. ${ }^{87}$

\footnotetext{
${ }^{84}$ ORGANISATION FOR ECONOMIC CO-OPERATION AND DEVELOPMENT - OECD. Acessado em 24 de dezembro de 2012 em http://www.oecd.org/about/history/.

${ }^{85}$ ORGANISATION FOR ECONOMIC CO-OPERATION AND DEVELOPMENT - OECD. Acessado em 24 de dezembro de 2012 em http://www.oecd.org/about/history/.

${ }^{86}$ ORGANISATION FOR ECONOMIC CO-OPERATION AND DEVELOPMENT - OECD. Acessado em 24 de dezembro de 2012 em http://www.oecd.org/about/history/.

${ }^{87}$ ORGANISATION FOR ECONOMIC CO-OPERATION AND DEVELOPMENT - OECD. Acessado em 24 de dezembro de 2012 em http://www.oecd.org/about/history/.
} 
O breve texto acima, tradução livre da história da OCDE constante em seu site oficial, se presta a demonstrar a relevância desta entidade para a economia mundial e a importância para qualquer legislação que, de alguma forma, trate de temas relacionados à economia, o que justifica a análise dos estudos dessa Organização acerca da matéria subcapitalização.

\subsubsection{Relevância da OCDE para as regras de subcapitalização}

Em seu livro sobre preços de transferência no direito brasileiro, Luís Eduardo Schoueri escreve que numa análise superficial, o intérprete poderia acreditar ser inútil, ou pelo menos não mandatória, a pesquisa das normas da OCDE para o entendimento da legislação brasileira acerca do transfer pricing. ${ }^{88}$

Afirma o professor que esse posicionamento basear-se-ia no fato de não ser o Brasil membro da OCDE e, portanto, não estar obrigado por qualquer de suas resoluções. Nesse sentido, dir-se-á com razão, que as normas expedidas pela OCDE não produzem efeito no Brasil. $^{89}$

Entretanto, essa conclusão na afasta o reconhecimento de que nossa legislação acerca do transfer pricing não é pioneira. Ao contrário, na exposição de motivos que encaminhou o projeto de lei que veio a se tornar a Lei $n^{\circ}$ 9.430/96, o Ministério da Fazenda já se manifestava:

12. As normas contidas nos arts. 18 a 24 representam significativo avanço da legislação nacional face ao ingente processo de globalização experimentado pelas economias contemporâneas. No caso específico, em conformidade com regras adotadas nos países integrantes da OCDE, são propostas normas que possibilitam o controle dos denominados "Preços de Transferência", de forma a evitar a prática, lesiva aos interesses nacionais, de transferência de recursos para o Exterior, mediante a manipulação dos preços pactuados nas importações ou exportações de bens, serviços ou direitos, em operações com pessoas vinculadas, residentes ou domiciliadas no Exterior.

"Inegável, pois, a tentativa, da parte do legislador nacional, de seguir os parâmetros da OCDE. Daí, pois, uma primeira razão para investigar se, efetivamente, o texto legal em

\footnotetext{
${ }^{88}$ SCHOUERI, Luís Eduardo. Ob. Cit. (nota 5), p. 19.
}

${ }^{89}$ SCHOUERI, Luís Eduardo. Ob. Cit. (nota 5), p. 19. 
vigor encontra-se em conformidade com regras adotadas nos países integrantes da OCDE". 90

Paulo Ayres Barreto segue a mesma linha e comenta a importância da OCDE ao afirmar que esta Organização goza de largo prestígio e alta reputação entre seus membros e entre a comunidade internacional de uma forma geral e, desta forma, suas decisões acabam por influir nas diversas ordens jurídicas instaladas, refletindo-se na legislação interna desses países. $^{91}$

Não é outra a conclusão no que se refere às normas de subcapitalização, pois, ainda que não conste referência explícita às regras da OCDE na exposição de motivos que acompanhou a Medida Provisória n ${ }^{\circ}$ 472/09 (que estabeleceu as regras de subcapitalização no Brasil), como é o caso da Lei ${ }^{\circ}$ 9.430/96, é notória a existência de vários elementos dos estudos desta Organização na legislação recentemente estabelecida no Brasil.

Desta forma, considerando que algumas das primeiras referências a subcapitalização surgiram em estudos e documentos dessa entidade, como o Transfer Pricing Guidelines, datado de $1979^{92}$, bem como se verifica a existência de trabalho especialmente voltado para o tema, aprovado pelo Conselho da OCDE em 26 de novembro de 1986 (OECD Thin Capitalisation) ${ }^{93}$, trabalho este que foi atualizado e publicado com título idêntico no ano de 2000, mostra-se bastante razoável adotar os estudos e documentos da OCDE como ponto de partida de qualquer estudo tratando do tema.

\subsubsection{Subcapitalização no âmbito da OCDE}

Considerando que há um trabalho desenvolvido pela OCDE especialmente voltado para o tema subcapitalização, tomaremos por base esse documento para os comentários deste item, fazendo a devida correlação com outros documentos desta entidade, quando aplicável.

\footnotetext{
${ }^{90}$ SCHOUERI, Luís Eduardo. Ob. Cit. (nota 5), p. 19.

${ }^{91}$ BARRETO, Paulo Ayres. Ob. Cit., p. 101.

92 ORGANISATION FOR ECONOMIC CO-OPERATION AND DEVELOPMENT - OECD. Ob. Cit. (nota 21).

${ }^{93}$ ORGANISATION FOR ECONOMIC CO-OPERATION AND DEVELOPMENT - OECD. Thin

Capitalisation. (adopted by the OECD Council on 26 November 1986). Paris: OCDE, 2010.
} 
O estudo sobre subcapitalização aprovado pelo Conselho da OCDE em 26 de novembro de 1986 (OECD Thin Capitalisation) é bastante detalhado: a) no primeiro capítulo trata do problema identificado, b) no segundo capítulo fala sobre as práticas adotadas pelos diversos países membros da Organização, c) no terceiro capítulo trata da relevância dos tratados para evitar a dupla-tributação, d) no quarto capítulo cuida da aplicação prática do princípio arm’s length e, por fim, e) o quinto capítulo trás conclusões e sugestões. $^{94}$

Ao abordar o problema no capítulo 1, esclarece o relatório que o método adotado pelas companhias para estabelecer o seu capital (via emissão de ações representativas de capital ou via empréstimos), afeta a tributação do imposto corporativo, pois alguns países adotam tributação sobre capital e outros permitem a dedução de despesas relativas a financiamento (empréstimos). Desta forma, o equilíbrio entre esses dois métodos de financiamento é, algumas vezes, referido como problemas de subcapitalização.

Após explicar as diferenças legais e econômicas entre as duas formas de financiamento, esclarece o relatório que, enquanto o capital (equity) é desenhado para produzir retorno ao investidor sobre a forma de distribuição de resultados tributados ou dividendos não dedutíveis do imposto corporativo; o retorno sobre empréstimos (debt) é considerado uma despesa (para quem paga) registrada antes da apuração do resultado, ou seja, uma despesa dedutível do imposto corporativo.

Tendo em vista o tratamento tributário diferente entre as duas formas de financiamento, afirma o relatório que geralmente é mais vantajoso, do ponto de vista tributário, ter mais empréstimos (debt) do que capital (equity) e esse situação tem gerado preocupações nas autoridades fiscais.

No capítulo 2, ao tratar das práticas adotadas pelos países membros como resposta ao problema relatado no capítulo 1, a OCDE descreve quatro grupos de legislações diferentes tendentes a regular a subcapitalização.

\footnotetext{
${ }^{94}$ ORGANISATION FOR ECONOMIC CO-OPERATION AND DEVELOPMENT - OECD. Thin Capitalisation. Ob. Cit. (nota 93), p. 1.
} 
O primeiro grupo de legislações descrito pela OCDE se refere aos países onde há vedação à dedução da despesa excessiva com os juros, nestes casos, são considerados excessivos os juros que não observam condições de mercado, ou seja, que não atendem o princípio arm's length.

O segundo grupo de legislações identificado se refere às situações em que além da vedação à dedução da despesa excessiva com os juros, como referido no primeiro caso, a legislação local considera ainda esse excesso como dividendos, lhe aplicando tratamento tributário oneroso.

O terceiro tipo de legislação descrito pela OCDE aborda às situações em que a natureza hibrida do financiamento não permite afirmar tratar-se de debt ou equity e, determinados países, buscam estabelecer esta diferença no plano legal, porém, neste caso, a forma de solucionar a questão não é uniforme entre os países membros, sendo que determinados instrumentos como empréstimos com participação podem ser tratados como capital (equity) e outros casos de natureza semelhante, como títulos conversíveis, podem ser tratados como empréstimo (debt) até a conversão e capital (equity) após a conversão.

Por fim, há casos em que o mero endividamento excessivo tem como conseqüência o tratamento dos juros como distribuição de lucro, não havendo qualquer juízo de valor quanto às condições de mercado ou natureza do financiamento.

Como conclusão dos capítulos 1 e 2, afirma a OCDE que de maneira geral, independentemente do modelo de legislação adotada, as regras adotadas pelos diversos países membro da organização buscam comparar as condições do contrato celebrado às condições de mercado e avaliar se há abusos ou desproporção nas condições de contratação, cláusulas do contrato, etc.

\subsubsection{Subcapitalização e a convenção modelo}

No capítulo 3 do relatório Thin Capitalisation, a OCDE atribui especial relevância ao tema da subcapitalização na interpretação dos tratados para evitar a dupla tributação, 
estabelecidos de acordo com a sua Convenção Modelo e faz comentários específicos sobre alguns artigos, tais como o art. 9, 10, 11, 23 e 24 da convenção modelo.

Com relação ao artigo 9, o relatório trata do princípio arm's length e afirma que as condições nas relações comerciais e financeiras entre partes relacionadas podem diferir das condições nas mesmas relações entre partes não relacionadas.

Nesta linha, observa Heleno Torres que o artigo 9 atribuiu competência aos Estados para controle de preços nas relações entre empresas controladas, coligadas ou de alguma forma conexas entre si, para determinar a efetiva base de cálculo da pessoa residente. ${ }^{95}$

Desta forma, o artigo 9 da convenção modelo dá suporte para definir qual o montante dedutível de juros e, conseqüentemente, passível de reduzir os resultados tributáveis do devedor, pois autoriza as autoridades fiscais do estado contratante a ajustar o resultado tributável da empresa, caso haja resultados que não foram reconhecidos, mas o seriam em uma situação de mercado (arm's length).

Em relação aos artigos 10 (que trata de dividendos) e 11 (que trata de juros) da convenção modelo, a questão que se coloca é qual a posição a ser adotada pela regulamentação tendente a disciplinar a subcapitalização, pois, podem ocorrer situações onde determinado valor deve ser considerado juro para fins da convenção modelo e, para a legislação interna do país, deve ser tratado como dividendo (ou vice-versa).

Neste sentido, esclarece o relatório que os artigos 10 e 11 se referem, principalmente, ao tratamento do recebimento dos dividendos ou juros e não lidam diretamente com a questão da dedutibilidade, como é o caso explícito do artigo 24 da convenção modelo.

Em relação ao artigo 23 da convenção modelo, afirma a OCDE que é importante decidir se o pagamento de juro que teve a sua dedução não autorizada e foi tratado como dividendo pelo país fonte, deveria ser tratado como juro ou dividendo pelo país de

${ }^{95}$ TÔRRES, Heleno. Ob. Cit., p. 518 
residência do recebedor e, com relação especificamente a este ponto, o tratamento muda de país para país.

Observa Heleno Tôrres que o artigo 23 se presta a afirmar que cabe ao país de residência do beneficiário, a responsabilidade de adotar as medidas destinadas a impedir os casos de bitributação internacional. ${ }^{96}$

A análise do artigo 24 da convenção modelo suscita questão relevante: o artigo de não discriminação evita o tratamento dos juros como distribuição de lucros assim definido nas regras da subcapitalização? Questiona-se ainda se o tratamento diferenciado se aplicaria apenas ao pagamento para não residentes.

A conclusão do relatório da OCDE neste ponto é que, aparentemente, o artigo 24 não evita o tratamento diferenciado entre residentes e não residentes, em outras palavras, $o$ artigo 24 permite a reclassificação dos juros como distribuição de lucros, sendo possível estabelecer esse tratamento apenas para não residentes, sem que com isso se desrespeite a convenção modelo.

3.3.1.4 Aplicação prática do princípio arm's length às regras de subcapitalização segundo a OCDE

Em capítulo importante do trabalho (capítulo 4), o relatório da OCDE aborda a aplicação prática do princípio arm's length em relação às regras de subcapitalização e afirma ser recomendável a observação do art. 9 da Convenção Modelo.

Aponta o relatório Thin Capitalisation que a aplicação do princípio arm’s length foi brevemente tratado em 1979 no relatório "Transfer Pricing and Multinational Enterprises" que já indicava que a subcapitalização poderia criar problemas para as autoridades fiscais e descrevia as diversas formas que isso pode ocorrer, como por exemplo, determinada operação ser tratada como empréstimo em um país e como capital em outro, gerando possibilidade de arbitragem quanto à localidade de estabelecimento de uma empresa.

${ }^{96}$ TÔRRES, Heleno. Ob. Cit., p. 539. 
Por seu turno, referido relatório descrevia as possíveis formas de lidar com o problema, como por exemplo, a harmonização das legislações domésticas de maneira a atenuar os conflitos.

A conclusão do relatório Transfer Pricing and Multinational Enterprises no item 191 foi reproduzida no relatório Thin Capitalisation, onde a OCDE trouxe a recomendação de uma abordagem relativamente flexível acerca das regras de subcapitalização.

Considerando que a OCDE recomendou abordagem flexível das regras de subcapitalização e afirmou que as condições especiais de cada caso individual devem ser consideradas; pode-se afirmar que a Organização criticou a adoção de regras rígidas de proporção equity x debt para solução dos problemas decorrentes da determinação da natureza de transações financeiras e privilegiou a adoção do princípio arm's length para a solução destes problemas.

O relatório Thin Capitalisation afirma ainda que as práticas de financiamento diferem de maneira relevante de um país para outro e de uma categoria de empresa para outra e, por esta razão, as regras em geral consideram (ou devem considerar) vários fatores para distinguir empréstimos de capital. Nesta linha, considera-se que a regra fundada no fato do detentor das ações / quotas ser um não-residente, também não é apropriada quando aplicada genericamente.

O comentário final enfatiza que a aplicação das regras tendentes a lidar com a subcapitalização não deve aumentar os resultados tributáveis de empresas domésticas para valores superiores aos resultados tributáveis que seriam reconhecidas em situações de mercado (arm's length situation).

Finalmente, o relatório da OCDE reitera que as regras nacionais relativas à subcapitalização devem ser suficientemente flexíveis para evitar ou anular eventual dupla tributação decorrente de diferente interpretação de determinada operação (equity $x$ debt) e casos concretos devem ser resolvidos por meio de acordo mútuo, via acordos para evitar a dupla tributação. 
Em resumo, podemos afirmar que a OCDE vai além da simples comparação entre as diversas legislações relativas à subcapitalização, e orienta os países a adotarem regras de subcapitalização flexíveis, que observem e respeitem as particularidades de cada transação e o tipo de empresa e, eventuais conflitos, devem ser resolvidos por meio de acordos para evitar a dupla tributação.

Nesse sentido, nos parece que há uma crítica às regras que adotam proporções fixas entre equity e debit (safe havens), havendo indicação que a adoção do princípio arm's length pode ser mais adequada, na medida em que respeitaria as referidas particularidades.

Por outro lado, não nos parece haver uma determinação expressa da OCDE para que os seus países membros adotem o princípio arm's length para as regras de subcapitalização.

Realizados os comentários acerca dos estudos da OCDE sobre subcapitalização, passamos à análise das regras específicas dos países selecionados para estudo.

\subsubsection{Estados Unidos}

A tributação corporativa dos Estados Unidos sobre a renda está entre as mais altas do mundo, composta pela alíquota do imposto de renda federal de $35 \%$, acrescida da tributação estadual, chegando a aproximadamente $40 \%$ de tributação sobre a renda.

No que tange a tributação da receita de juros, não há qualquer tratamento diferenciado, sendo que esta é tributada a mesma alíquota de $35 \%$, por outro lado, genericamente falando, os Estados Unidos permitem a dedução do valor dos juros para quem os paga. ${ }^{97}$

Stuart Webber afirma que uma tributação tão elevada pode incentivar a prática da subcapitalização. Desta forma, preocupado com potencial prática de subcapitalização, os Estados Unidos estabeleceram regras tendentes a evitar (ou limitar) a subcapitalização em 1989, estabelecendo um limite de endividamento entre empresas vinculadas ou

\footnotetext{
${ }^{97}$ LUND, Henrik; KORSGAARD, Carina Marie e ALBERTSEN, Mathias. Ob. Cit., p. 349
} 
relacionadas na ordem de 1.5:1, ou seja, as empresas poderiam ter endividamento com vinculadas na proporção equivalente a uma vez e meia o seu capital. ${ }^{98}$

De acordo com a regra de subcapitalização, quando essa condição fosse atingida, e a despesa de juros fosse superior a 50\% do lucro tributável, a porção acima dos 50\% seria não dedutível. Desta forma, as duas condições deveriam ser atingidas para que houvesse limitação da dedução da despesa com juros. ${ }^{99}$

Interessante observar que de acordo com a pesquisa conduzida por funcionários da empresa de auditoria KPMG do Reino Unido anteriormente citada, os Estados Unidos não possuem regras explícitas que restringem a dedução dos juros por causa de regras de subcapitalização, desta forma, as regras mencionadas acima são parte das regras antielisão, dentro da categoria de earnings stripping. ${ }^{100}$

A visão adotada no estudo da KPMG não nos parece ser a mais acertada, visto que, em nossa opinião, os limites adotados pelos Estados Unidos para limitar o endividamento configuram regras de subcapitalização.

As regras acima referidas foram inicialmente estabelecidas apenas para transações entre partes relacionadas, mas em 1993 a abrangência da lei foi ampliada para empréstimos entre partes não relacionadas, caso garantidos por estrangeiros ou entidades imunes. ${ }^{101}$

Considerando o conceito exposto no item 3.1, entendemos que o limite estabelecido pela regra americana pode ser considerado um safe harbour ou safe haven, na medida em que as regras exigem determinada proporção mínima entre o capital aportado pelos sócios e o endividamento total da empresa para permitir (ou não) a dedução de despesas de juros pagos em decorrência do endividamento (debt).

\footnotetext{
${ }^{98}$ WEBBER, Stuart. Ob. Cit., p. 690.

${ }^{99}$ WEBBER, Stuart. Ob. Cit., p. 690.

${ }^{100}$ LUND, Henrik; KORSGAARD, Carina Marie e ALBERTSEN, Mathias. Ob. Cit., p. 349.

${ }^{101}$ WEBBER, Stuart. Ob. Cit., p. 690.
} 
Esta também é a opinião de Stuart Webber que afirma que a proporção 1.5:1 é considerada um safe harbour e quando a proporção empréstimo x capital (debt-to-equity) estiver abaixo deste limite, a receita federal americana não irá questionar se o empréstimo é excessivo ou não. Por seu turno, caso a proporção 1.5:1 seja excedida, a receita federal americana pode ou não considerar o empréstimo excessivo, baseado no exame de todos os fatos e circunstancias relevantes. ${ }^{102}$

Com relação a empréstimos entre partes não relacionadas (e não garantidos por estrangeiros ou entidades imunes), os Estados Unidos não possuem regras específicas e um proporção de 3:1 é usualmente aceita pelas autoridades fiscais, desde que o contribuinte consiga pagar esse débito sem auxilio de partes relacionadas. ${ }^{103}$

Preocupado com eventual evasão fiscal decorrente de situações de subcapitalização, dentre outros motivos, o congresso americano solicitou ao tesouro americano, em 2004, estudo sobre o impacto da subcapitalização na receita tributável, solicitação esta que resultou em dois estudos diferentes. ${ }^{104}$

No primeiro estudo, foi comparada a rentabilidade de empresas estrangeiras (com mais de 50\% do capital estrangeiro) com empresas locais (detidas por americanos) e, caso a rentabilidade das empresas estrangeiras fosse menor que a rentabilidade das empresas locais, isso poderia ser um indicativo de transferência de resultados para fora dos Estados Unidos, entretanto, o estudo não chegou a uma conclusão satisfatória. ${ }^{105}$

Parece-nos que um dos motivos para o primeiro estudo não ter chegado a uma conclusão satisfatório se deveu ao fato do escopo não ter sido adequadamente definido, sendo exigida uma análise bastante ampla e que, não necessariamente trataria resultados concretos, visto que diversos fatores podem influenciar na rentabilidade de determinada empresa.

\footnotetext{
${ }^{102}$ WEBBER, Stuart. Ob. Cit., p. 690.

${ }^{103}$ ERNST \& YOUNG. The 2011 Worldwide corporate tax guide. EYGM, 2011, p. 1231.

${ }^{104}$ WEBBER, Stuart. Ob. Cit., p. 690.

${ }^{105}$ WEBBER, Stuart. Ob. Cit., p. 690.
} 
No segundo estudo, o tesouro americano analisou a conduta das empresas internacionais para determinar se estas estavam engajadas em atividades de transferência de resultados, sendo que o esse segundo estudo sugeriu que as empresas internacionais estavam transferindo parte relevante dos seus resultados tributáveis para fora dos Estados Unidos, principalmente por meio do pagamento de juros. Em outras palavras, as regras de subcapitalização então vigentes não estavam sendo efetivas para controlar essas atividades. $^{106}$

As conclusões deste segundo estudo apresentam maior robustez, visto que o escopo foi restrito e a investigação foi bastante específica com relação a eventual transferência de resultado, especialmente via pagamento de juros.

Em decorrência destes estudos, o governo americano propôs, no início do ano 2009, algumas medidas para tentar reduzir a transferência de resultados para fora dos Estados Unidos, com a conseqüente redução do tributo corporativo recolhido aos cofres americanos, entretanto, referidas medidas não foram aprovadas. ${ }^{107}$

Desta forma, as regras anteriormente descritas, continuam válidas ainda hoje, sendo possível que ocorram mudanças no curto prazo, em função da pressão para o aumento da arrecadação americana.

Considerando as regras atualmente vigentes, podemos afirmar que as regras americanas de subcapitalização se mostram bastante simples e objetivas, entretanto, carecem de flexibilidade e não atentam para os diferentes níveis de endividamento nos diferentes setores da economia, não havendo, por exemplo, diferenciação entre o setor financeiro e não financeiro.

Adicionalmente, as regras americanas também não avaliam à adequação da despesa de juros às condições de mercado, o que pode ser um equívoco.

\footnotetext{
${ }^{106}$ WEBBER, Stuart. Ob. Cit., p. 691.

${ }^{107}$ WEBBER, Stuart. Ob. Cit., p. 691.
} 


\subsubsection{Europa}

Tendo analisado as regras e comentários da OCDE, cuja importância foi relatada no item específico, bem como as regras dos Estados Unidos, atualmente a maior economia mundial, passamos a analisar as regras de países relevantes do continente europeu, dado o peso destes para a economia mundial, bem como a influência da sua produção jurídica, em especial para economias em desenvolvimento, tais como os chamados BRIC (Brasil, Rússia, Índia e China).

\subsubsection{Alemanha}

A Alemanha implementou, inicialmente, limitações de endividamento em função do capital (debt-to-equity limitation) para controlar o endividamento excessivo, adotando a mesma proporção que os Estados Unidos: 1.5:1 para a maioria das situações, e uma proporção de 3:1 para holdings. ${ }^{108}$

As regras estabelecidas na Alemanha tinham como objetivo o combate a situações onde a parte relacionada, estabelecida em outro país, concedia empréstimos relevantes para a empresa alemã, a fim de transferir resultados da Alemanha para outros países. ${ }^{109}$

As regras de subcapitalização inicialmente estabelecidas, tinham como foco evitar as estratégias de financiamento abusivo, onde o mutuante era um acionista estrangeiro ou parte relacionada. Entretanto, as regras alemãs foram questionadas perante o Tribunal Europeu de Justiça no caso Lankhorst-Hoborst GMbH contra Finanzamt Steinfurt. ${ }^{110}$

No julgamento do referido caso, ocorrido em 2002, o Tribunal Europeu de Justiça entendeu que a regra anti-abuso alemã violou a liberdade de estabelecimento, definida no artigo 43 do tratado que instituiu a Comunidade Européia. ${ }^{111}$

\footnotetext{
${ }^{108}$ WEBBER, Stuart. Ob. Cit., p. 692.

${ }^{109}$ WEBBER, Stuart. Ob. Cit., p. 692.

${ }^{110}$ A integra do acórdão está disponível em: <http://curia.europa.eu/juris/showPdf.jsf?text=\&docid= 47587\&pageIndex=0\&doclang=PT\&mode=lst\&dir=\&occ=first \&part=1\&cid=173659>, acessado em 31/12/2012.

${ }^{111}$ WEBBER, Stuart. Ob. Cit., p. 692.
} 
No caso concreto, a sociedade alemã era $100 \%$ detida por uma sociedade estabelecida na Holanda. Em 1996, ocorreu um aumento de capital na empresa alemã, para 2 milhões de marcos e, posteriormente, esta sociedade contraiu um empréstimo de 3 milhões de marcos, a serem pagos em 10 prestações anuais, incidindo juros de 4,5\% ao ano; sendo relevante observar que a sociedade alemã já possuía uma dívida de 3,7 milhões de marcos com uma instituição financeira, sendo que o empréstimo contraído com a matriz foi utilizado para amortizar grande parte da dívida com a instituição financeira não vinculada e, conseqüentemente, diminuir a despesa de juros, visto que a taxa de juros do novo empréstimo era menor que a taxa de juros paga para a instituição não vinculada. ${ }^{112}$

A autoridade fiscal negou a dedução dos juros pela sociedade alemã e equiparou o pagamento a uma distribuição de dividendos, sob o argumento que uma parte não relacionada não teria concedido empréstimo nas mesmas condições, dado o alto nível de endividamento da sociedade tomadora do empréstimo. ${ }^{113}$

O Tribunal Europeu de Justiça considerou que a regra alemã contrariava o princípio do livre estabelecimento, contido no artigo 43 do tratado da Comunidade Européia, pois tratava de maneira desigual empresas doméstica e empresas internacionais, na medida em que um empréstimo concedido por um sócio alemão (a uma empresa alemã) e requalificado como distribuição de dividendos, daria direito a um crédito tributário ao sócio, em montante equivalente aos tributos exigidos; ao passo que o empréstimo concedido por um sócio estrangeiro e requalificado como distribuição de dividendos, seria tributado à alíquota de $30 \%$, sem direito a crédito. ${ }^{114}$

A decisão ainda pontuou que embora os Estados-Membros tenham a sua competência tributária assegurada, estes devem exercê-la com respeito ao direito comunitário e abster-se, em particular, de qualquer discriminação em razão da nacionalidade, conforme diversos precedentes citados na decisão. ${ }^{115}$

\footnotetext{
${ }^{112}$ BISPO, Rafael Minervino. As regras de subcapitalização no direito tributário brasileiro. Dissertação (Mestrado em Direito) - Pontifícia Universidade Católica de São Paulo - PUC-SP, São Paulo, 2012, p. 87.

${ }^{113}$ WEBBER, Stuart. Ob. Cit., p. 692.

${ }^{114}$ WEBBER, Stuart. Ob. Cit., p. 692.

$115<$ http://curia.europa.eu/juris/showPdf.jsf?text=\&docid=47587\&pageIndex=0\&doclang=PT\&mode= lst \&dir=\&occ=first \&part=1\&cid=173659>, acessado em 31/12/2012, p. 10 .
} 
Em resposta a decisão do Tribunal Europeu de Justiça, o governo alemão modificou a legislação de subcapitalização, ampliando o seu escopo para alcançar todos os empréstimos, incluindo os empréstimos concedidos por sócios residentes na Alemanha, o que, na prática, não eliminou totalmente as desigualdades entre sócios residentes na Alemanha e fora do país, remanescendo ainda algumas exceções. ${ }^{116}$

Buscando ao mesmo tempo simplificar a legislação tributária e tornar o país mais atrativo para investidores, o governo alemão decidiu mudar novamente as regras de subcapitalização em 2008, abandonando o conceito de proporção dívida x capital para uma limitação na dedução da despesa de juros. ${ }^{117}$

A reforma tributária de 2008 introduziu um novo conceito para a restrição de dedução de juros, sendo a restrição aplicável independentemente do fato dos juros serem pagos a uma parte relacionada ou não, como por exemplo, um banco local não vinculado. $^{118}$

A nova regra de limitação de despesa de juros passou a abranger empresas sediadas na Alemanha, estabelecimentos permanentes mantidos neste país, bem como sociedades (partnerships) com filiais alemãs, sendo consideradas excessivas as despesas de juros superiores a 30\% do resultado tributável, antes da dedução dos juros, tributos, depreciações e amortizações (EBITDA). ${ }^{119}$

A regra de 2008 e hoje vigentes comporta algumas exceções e não é aplicada, caso uma das 3 condições a seguir seja satisfeita:

a) a despesa anual com juros seja menor que 3 milhões de euros;

b) a atividade principal da empresa alemã não esteja totalmente consolidada no resultado global do grupo econômico, tanto para fins financeiros como para fins de controle societário; e

c) a empresa alemã pertença a um grupo internacional e a proporção de capital em relação aos ativos seja igual ou menor que $2 \%$ da proporção capital x ativos do

\footnotetext{
${ }^{116}$ WEBBER, Stuart. Ob. Cit., p. 693.

${ }^{117}$ WEBBER, Stuart. Ob. Cit., p. 693.

${ }^{118}$ ERNST \& YOUNG. Ob. Cit., p. 388.

${ }^{119}$ ERNST \& YOUNG. Ob. Cit., p. 388.
} 
grupo internacional. Em outras palavras, se a subsidiária alemã é menos capitalizada que o grupo internacional ou é capitalizada em não mais que $2 \%$ que o grupo como um todo, a empresa alemã não tem terá sua despesa com juros limitada. ${ }^{120}$

Ao analisar a nova regra alemã, observa Stuart Weber que estas não estão totalmente livres de questionamento no que concerne ao artigo 43 do tratado da Comunidade Européia, pois a legislação tributária alemã permite que uma matriz e uma subsidiária alemãs podem ser tratadas como um único negócio, ao passo que essa oportunidade não é assegurada as situações que envolvem uma matriz sediada fora da Alemanha. $^{121}$

Verificamos que um dos objetivos implícitos da nova regra alemã é evitar a transferência de resultados para fora da Alemanha por meio de empréstimos excessivos, na mesma linha das medidas propostas em 2009 pelo governo americano e não aprovadas.

Algumas das críticas formuladas à regra americana também poderiam ser formuladas acerca da regra alemã, na medida em que estas não atentam para os diferentes níveis de endividamento nos diferentes setores da economia, não havendo, por exemplo, diferenciação entre o setor financeiro e não financeiro, bem como também não avaliam à adequação da despesa de juros às condições de mercado.

\subsubsection{Reino Unido}

Desde os anos 90, o Reino Unido tem tentado coibir as estruturas com alto índice de financiamento por meio de legislações específicas, tendo alterado a regra de subcapitalização 3 vezes entre 1994 e 2004, alterações estas que buscaram introduzir o princípio arm's length e, ao mesmo tempo, garantir tratamento igualitário entre empresas residentes no Reino Unido e residentes na Comunidade Européia. ${ }^{122}$

Neste sentido, podemos dividir a legislação britânica em 4 períodos:

\footnotetext{
${ }^{120}$ ERNST \& YOUNG. Ob. Cit., p. 389.

${ }^{121}$ WEBBER, Stuart. Ob. Cit., p. 693.

${ }^{122}$ WEBBER, Stuart. Ob. Cit., p. 694.
} 
a) Até 1995, a legislação de subcapitalização previa que os juros eram integralmente indedutíveis, caso o empréstimo fosse concedido por uma sociedade não residente e que possuísse $75 \%$ de participação societária na sociedade britânica, ou a mutuante e a mutuaria fossem filias de uma terceira empresa que possuísse tal participação;

b) Entre 1995 e 1998, configurada a participação societária referida no item anterior, os juros somente seriam indedutíveis se superassem o que teria sido pago, caso não existisse uma relação especial entre o devedor (exceção feita às hipóteses em que ambas as sociedades estivessem sujeitas à tributação no Reino Unido e, neste caso, os juros seriam integralmente dedutíveis);

c) Entre 1998 e 2004, na hipótese de haver vinculação entre as sociedades (em um conceito amplo, incluindo o controle direto ou indireto), a dedutibilidade dos juros deveria obedecer às regras de preço de transferência, ocorrendo a aplicação do princípio arm's length (limitada às sociedades vinculadas); e

d) A partir de 2004, as regras já vigentes a partir de 1998, passaram a ser aplicadas também às hipóteses em que ambas as sociedades eram tributadas pelo imposto britânico. $^{123}$

Considerando a regra vigente a partir de 1998, uma empresa britânica será considerada subcapitalizada quando possuir endividamento excessivo em relação a sua capacidade de endividamento, segundo condições de mercado (arm's length borrowing capacity), podendo ensejar uma dedução excessiva de juros. ${ }^{124}$

Nesse sentido, a capacidade de endividamento segundo condições de mercado pode ser entendida como o volume de empréstimos que a empresa britânica poderia obter de uma empresa independente, sob a perspectiva de uma empresa individual e não parte de um grupo internacional. ${ }^{125}$

Como resultado, para determinar se uma companhia está subcapitalizada, deve-se comparar o volume de empréstimos que esta empresa poderia obter de uma parte independente com o volume efetivamente emprestado por empresas do grupo (ou com

\footnotetext{
${ }^{123}$ BISPO, Rafael Minervino. Ob. Cit., p. 88.

${ }^{124}$ WEBBER, Stuart. Ob. Cit., p. 694.

${ }^{125}$ WEBBER, Stuart. Ob. Cit., p. 694.
} 
garantia de empresas do grupo) e, caso o segundo valor seja superior ao primeiro, os juros excedentes não serão dedutíveis. ${ }^{126}$

Interessante observar que a regra britânica também é aplicável quando há empréstimos entre empresas ligadas, mas devido à estrutura final adotada, o devedor formal é uma parte não relacionada. Neste sentido, pode-se afirmar que a regra britânica busca a chamada substância sobre a forma, na medida em que não olha apenas para o mutuário formal, mas para toda a estrutura de financiamento. ${ }^{127}$

A verificação da adequação (e consequente dedutibilidade) da despesa com juros ao princípio arm's length deve ser feita pelos próprios contribuintes e a receita federal britânica pode contestar a dedução, sob o argumento que considerando todas as circunstancias, o empréstimo não seria realizado no montante total recebido ou teria sido exigida uma taxa de juros menor que a efetivamente praticada, caso o mutuário fosse uma parte não relacionada atuando segundo preços e condições de mercado (arm's length). ${ }^{128}$

Entretanto, as regras são bastante genéricas e não tem uma indicação clara para os contribuintes do valor que deve (ou não) ser considerado excessivo, o que pode resultar em alto índice de contencioso e ineficiência da regra, sendo talvez esse o motivo para que nenhum outro país, dentre as principais economias do mundo, tenha adotado essa abordagem. $^{129}$

Interessante observar ainda que, conforme relata Stuart Webber, diversos estudos tem demonstrado que é prática comum das companhias britânicas tomarem empréstimos com partes não relacionadas em montantes inferiores às linhas disponíveis, como um sinal de saúde financeira dado aos investidores externos. Essa prática foi observada em $88 \%$ das companhias estudadas. ${ }^{130}$

\footnotetext{
${ }^{126}$ WEBBER, Stuart. Ob. Cit., p. 694.

${ }^{127}$ WEBBER, Stuart. Ob. Cit., p. 694.

${ }^{128}$ ERNST \& YOUNG. Ob. Cit., p. 1185.

${ }^{129}$ WEBBER, Stuart. Ob. Cit., p. 695.

${ }^{130}$ WEBBER, Stuart. Ob. Cit., p. 695.
} 
Por outro lado, isso também permite que essas empresas se utilizem de empréstimos com partes relacionadas, apenas para reduzir os tributos devidos, o que pode demonstrar que a regra britânica é muito branda e não traz os resultados desejados.

Além dos problemas acima relatados, da mesma forma que as regras alemãs, as regras de subcapitalização do Reino Unido também foram questionadas perante o Tribunal Europeu de Justiça acerca da sua adequação ao artigo 43 do tratado que instituiu a Comunidade Européia, no caso conhecido por Test Claimants in the Thin Cap Group Litigation contra Commissioners of Inland Revenue, julgado em 2007. ${ }^{131}$

A decisão do tribunal seguiu linha semelhante à decisão do caso Lankhorst-Hoborst $\mathrm{GMbH}$ contra Finanzamt Steinfurt, identificando violação ao artigo 43 do tratado, entretanto, o tribunal consignou que não seria considerado violação à liberdade de estabelecimento, caso a legislação:

(i) considerasse aspectos objetivos e verificáveis que permitissem analisar a existência de expediente artificial visando economia fiscal;

(ii) franqueasse ao sujeito passivo a possibilidade de demonstrar que a operação obedeceu a critérios de mercado;

(iii) qualificasse como lucros distribuídos apenas os juros que excedessem ao montante que teriam sido pactuados em um ambiente de plena concorrência. ${ }^{132}$

Ademais, o acórdão consignou que a legislação seria contrária às regras comunitárias apenas em relação às transações efetuadas entre empresas controladas por sociedades pertencentes à Comunidade Européia e, operações em que o controlador é de um terceiro país ou operações realizadas por intermédio de uma empresa sediada em um país fora da Comunidade Européia, não seriam alcançadas pela vedação contida no acórdão.

Observando as possíveis fraquezas e inconsistências da norma vigente, bem como a não adequação ao artigo 43 do tratado que instituiu a Comunidade Européia, o governo

\footnotetext{
${ }^{131}$ A integra do acórdão está disponível em: <http://curia.europa.eu/juris/showPdf.jsf?text=\&docid= 62137\&pageIndex=0\&doclang=PT\&mode=lst\&dir=\&occ=first \&part=1\&cid=172871>, acessado em 31/12/2012.

${ }^{132}$ BISPO, Rafael Minervino. Ob. Cit., p. 89.
} 
inglês propôs em 2009 uma nova legislação, chamada de worldwide debt cap (WWDC) e que entrou em vigor em $1^{\circ}$ de janeiro de 2010.

As novas regras têm como objetivo limitar a dedução da despesa de juros para grupos de empresas que tenham a maior parte dos seus débitos no Reino Unido, assim entendido o endividamento das empresas sediadas no Reino Unido excedente a $75 \%$ do endividamento global do grupo. ${ }^{133}$

Caso o endividamento das empresas sediadas no Reino Unido exceda a $75 \%$ do endividamento global do grupo (chamado de gateway test), os juros pagos pelas empresas inglesas em empréstimos com empresas ligadas será comparado com o custo financeiro total do grupo e o excesso será considerado não dedutível. ${ }^{134}$

O WWDC não é aplicado às empresas definidas como micro, pequenas ou médias, conforme definido em ato da receita federal inglesa, visto que, no entendimento deste órgão, o custo-benefício não seria positivo. Nesse sentido, a regra tem como foco grandes grupos econômicos e se aplica tanto para matrizes sediadas no Reino Unido, como para matrizes sediadas em outros países, mas com filiais no Reino Unido. ${ }^{135}$

Verificamos que as autoridades fiscais britânicas têm enfrentado os mesmos desafios encontrados pelas autoridades alemãs, no sentido de buscar alternativas para evitar transferências de resultados para fora do Reino Unido e, ao mesmo tempo, respeitar o tratado que instituiu a Comunidade Européia.

A regra inglesa se mostra complexa e sujeita a questionamentos, como efetivamente já ocorreu perante o Tribunal Europeu de Justiça, por outro lado, os critérios adotados levam em conta condições de mercado (arm's length) bem como o excesso de endividamento da empresa inglesa perante o endividamento médio do grupo, implicando em regra que nos parece mais justa e completa, quando comparada às regras americanas e alemãs.

\footnotetext{
${ }^{133}$ ERNST \& YOUNG. Ob. Cit., p. 1185.

${ }^{134}$ WEBBER, Stuart. Ob. Cit., p. 696.

${ }^{135}$ WEBBER, Stuart. Ob. Cit., p. 696.
} 


\subsubsection{França}

Até 2010, a legislação francesa de subcapitalização estava fundada na proporção dívida x capital (debt-to-equity ratio) para limitar o endividamento excessivo.

A proporção dívida x capital máxima admitida era de 1.5:1 e os juros eram não dedutíveis quando o valor excedesse a $25 \%$ do resultado antes dos impostos, assim entendido o lucro líquido, acrescido dos juros dos empréstimos intra-grupo e da depreciação. ${ }^{136}$

As regras foram alteradas a partir de 2011 e, de acordo com a regra geral de dedutibilidade, os pagamentos de juros são integralmente dedutíveis, com observância de certas restrições. ${ }^{137}$

De acordo com referidas regras, os juros decorrentes de empréstimos concedidos para entidades francesas por seus acionistas diretos, serão dedutíveis do lucro tributável quando observarem caso satisfaçam duas condições:

a) o capital da empresa francesa esteja integralmente integralizado;

b) a taxa de juros praticada no empréstimo concedido pelos acionistas diretos não exceda a taxa média de juros em empréstimos com prazo inicial maior que dois anos e concedidos à empresa francesa por bancos não vinculados. ${ }^{138}$

Adicionalmente à regra-geral de dedutibilidade de juros, foram estabelecidas regras de subcapitalização bastante complexas, que descrevemos a seguir.

De acordo com as regras de subcapitalização, os juros pagos para partes vinculadas (ou para terceiros, em empréstimos garantidos por partes relacionadas), somente serão dedutíveis se atenderem dois testes: arm's length test e thin-capitalization test.

Segundo o arm's length test, a taxa de juros é limitada pelo maior de dois valores:

\footnotetext{
${ }^{136}$ WEBBER, Stuart. Ob. Cit., p. 697.

${ }^{137}$ ERNST \& YOUNG. Ob. Cit., p. 347.

${ }^{138}$ ERNST \& YOUNG. Ob. Cit., p. 347.
} 
a) a taxa média anual de juros nos empréstimos concedidos por instituições financeiras e que tenham taxa de juros variável e prazo mínimo de dois anos;

b) a taxa de juros que seria praticada em um empréstimo com uma instituição financeira não vinculada, em circunstâncias de mercado.

Desta forma, os juros excedentes ao maior dos dois cálculos acima, serão considerados não dedutíveis e deverão ser adicionados ao resultado tributável da empresa. $^{139}$

Adicionalmente ao arm's length test, a empresa deve realizar teste chamado thincapitalization test e, mesmo que de acordo com o primeiro teste, os juros sejam integralmente dedutíveis, os juros excedentes aos 3 testes abaixo, serão considerados não dedutíveis:

a) teste de proporção dívida x capital seguindo a fórmula: "a" (montante de juros que atendeu a condição do arm's length test), vezes "b" (150\% do capital líquido da empresa tomadora do empréstimo), dividido por "c" (total do endividamento com partes vinculadas);

b) teste dos ganhos: $25 \%$ da receita corrente ajustada, assim entendida a receita operacional antes da dedução dos impostos, juros pagos a partes vinculadas, depreciação, amortização e algumas despesas de leasing;

c) teste da receita de juros: o montante de juros recebido pela empresa francesa de partes relacionadas. ${ }^{140}$

Se os juros considerados dedutíveis segundo o arm's length test excederam os 3 thin-capitalization test, o montante de juros que exceder o maior dos 3 thin-capitalization test será considerado não dedutível, exceto se o excesso for inferior a 150 mil euros. ${ }^{141}$

Os testes que limitam a dedutibilidade dos juros não são aplicáveis se a empresa francesa conseguir demonstrar que a proporção dívida x capital do seu grupo é maior que a sua proporção dívida x capital, sob o ponto de vista individual. ${ }^{142}$

\footnotetext{
${ }^{139}$ ERNST \& YOUNG. Ob. Cit., p. 348.

${ }^{140}$ ERNST \& YOUNG. Ob. Cit., p. 348.

${ }^{141}$ ERNST \& YOUNG. Ob. Cit., p. 348.

${ }^{142}$ ERNST \& YOUNG. Ob. Cit., p. 348.
} 
Das análises realizadas até aqui, a regra francesa vigente se mostra a mais complexa, o que pode significar pouca efetividade da mesma, na medida em que demanda uma série de controles, tanto por parte dos contribuintes, como por parte das autoridades fiscais.

\subsubsection{Países Emergentes}

Superadas as análises relativas à OCDE, Estados Unidos e países da Europa, passamos a analise das regras dos países emergentes, com o intuito de avaliar como países em situação econômica semelhante ao Brasil têm enfrentado esse tema.

\subsubsection{China}

As regras de subcapitalização da China são bastante simples e tomam por base a proporção dívida x capital (debt-to-equity ratio).

Desta forma, caso a proporção dívida x capital de uma empresa exceda um determinado padrão, previamente estabelecido, os juros excedentes não serão dedutíveis na apuração do lucro tributável. ${ }^{143}$

O padrão foi publicado em um ato do ministério da fazenda, que determinou que os juros decorrentes de empréstimos obtidos com partes relacionadas, somente serão dedutíveis se a proporção dívida x capital de 5:1 no caso de empresas financeiras e 2:1 no caso de empresas não financeiras for respeitada. ${ }^{144}$

O regulamento do imposto de renda das empresas ainda esclarece que além dos empréstimos dados por partes relacionadas, também estão sujeitos às regras de subcapitalização, os empréstimos concedidos por: a) empresas relacionadas, por meio de partes não relacionadas, b) partes não relacionadas, mas garantido por partes relacionadas

\footnotetext{
${ }^{143}$ MA, Shiqi. China (People's Rep.) - Corporate Taxation. Sec. 1 - Country Analyses IBFD: Amsterdam, 2011. ${ }^{144}$ MA, Shiqi. Ob. Cit.
} 
e; c) qualquer outro empréstimo dado indiretamente por uma parte relacionada e que tenha características de dívida. ${ }^{145}$

Em resumo, pode-se afirmar que os juros decorrentes qualquer empréstimo concedido direta ou indiretamente por uma parte relacionada, somente serão dedutíveis até o limite dívida x capital definido pelo ministério da fazenda, a depender do tipo de empresa: 5:1 no caso de instituições financeiras e 2:1 para empresas não financeiras.

Os juros excedentes aos limites acima especificados serão considerados dividendos e, portanto, sujeitos a incidência de imposto de renda. ${ }^{146}$

Apesar da regra Chinesa de subcapitalização adotar critério objetivo, fundado na proporção dívida x capital, há duas exceções que nos parecem bastante razoáveis e tornam as regras adequadamente flexíveis.

Caso a empresa demonstre por meio de documentos hábeis que: i) o empréstimo foi realizado com observância de condições de mercado (arm's length) ou ii) a taxa efetiva do imposto da empresa mutuaria não é superior à taxa efetiva do imposto da empresa mutuante; os limites de dívida x capital não serão aplicáveis e os juros pagos serão integralmente dedutíveis. ${ }^{147}$

Além das regras de subcapitalização de caráter fiscal, a China ainda estabeleceu limites regulatórios de capitalização para as chamadas Foreign investment entities, ou entidades estrangeiras de investimento.

De acordo com a regra regulatória Chinesa:

a) projetos de investimento até 3 milhões de dólares, precisam ter capital equivalente à, no mínimo, $70 \%$ do investimento;

b) projetos de investimento entre 3 e 10 milhões de dólares, precisam ter capital equivalente à, no mínimo, $50 \%$ do investimento, mas não menor que 2,1 milhões de dólares;

\footnotetext{
${ }^{145}$ MA, Shiqi. Ob. Cit.

${ }^{146}$ MA, Shiqi. Ob. Cit.

${ }^{147}$ MA, Shiqi. Ob. Cit.
} 
c) projetos de investimento entre 10 e 30 milhões de dólares, precisam ter capital equivalente à, no mínimo, $40 \%$ do investimento, mas não menor que 5 milhões de dólares;

d) projetos de investimento acima de 30 milhões de dólares, precisam ter capital equivalente à, no mínimo, 33,3\% do investimento, mas não menor que 12 milhões de dólares. $^{148}$

As regras chinesas parecem ser bastante eficazes, na medida em que combinam regras de safe harbour que observam os diferentes níveis de endividamento das empresas (diferenciam instituições financeiras e não financeiras), bem como parâmetros de mercado, por meio da aplicação do arm's length e análise da taxa efetiva de tributação da empresa mutuante e mutuaria.

\subsubsection{Rússia}

Na mesma linha que a China, a Rússia também adota duas regras para dedução de juros decorrentes de operações de dívida (debit): uma com base no princípio arm's length e outra com base em proporção fixa dívida x capital (debit-to-equity ratio), porém com características próprias.

De acordo com a regra fundada no princípio arm's length, os juros derivados de qualquer tipo de dívida são integralmente dedutíveis, desde que o montante dos juros não exceda substancialmente (em mais de $20 \%$ para mais ou para menos) o nível médio de juros exigido em outras obrigações no mesmo trimestre, considerando obrigações tenham condições comparáveis, assim entendidas obrigações que tenham como referência a mesma moeda, mesmo prazo de pagamento, montantes equivalentes e garantias similares. ${ }^{149}$

Quando não houver empréstimos bancários disponíveis no trimestre, em condições comparáveis, o contribuinte pode adotar um método alternativo, onde o montante máximo de juro dedutível será equivalente à taxa definida pelo Banco Central da Rússia ${ }^{150}$,

\footnotetext{
${ }^{148}$ ERNST \& YOUNG. Ob. Cit., p. 204.

${ }^{149}$ SHAMANOVA, Evgeniya. Rússia - Corporate Taxation. Sec. 7 - Country Analyses IBFD. Amsterdam, 2011.

${ }^{150}$ Em fevereiro de 2013, referida taxa era de $8,25 \%$
} 
multiplicada por um coeficiente de 1.1 para débitos denominados em Rublos (moeda russa) e $15 \%$ para empréstimos denominados em outras moedas. ${ }^{151}$

Interessante observar que, como uma forma de incentivar a economia russa, as regras foram temporariamente alteradas e entre 01 de janeiro de 2011 e 31 de dezembro de 2012, o coeficiente para empréstimos denominados em Rublos foi elevado para 1.8 e para empréstimos em outras moedas, o coeficiente foi elevado para $0.8 .^{152}$

Em complemento às regras de dedutibilidade fundadas no princípio arm's length, o artigo 269 do código tributário russo, contem regras de subcapitalização, fundadas em proporção fixa dívida x capital.

As regras específicas de subcapitalização são aplicáveis exclusivamente para empréstimos concedidos por acionistas da companhia russa, não residentes e que detenham, direta ou indiretamente, mais de $20 \%$ do capital daquela companhia. ${ }^{153}$

O conceito de empresa vinculada adotado pela legislação russa é bastante objetivo, ou seja, $20 \%$ do capital da companhia russa detido direta ou indiretamente por um não residente. Em que pese a objetividade por vezes permitir eventuais manobras para evitar a aplicação da regra, o valor da regra objetiva e clara deve ser ressaltado, visto que facilita a sua aplicação, tanto na perspectiva do contribuinte, como na perspectiva da administração pública.

De acordo com as regras de subcapitalização russa, a proporção dívida x capital máxima é de 3:1 para empresas em geral e 12.5:1 para empresas com atividades bancárias e de leasing. A adequação à proporção dívida x capital deve ser realizada ao final de cada período de verificação, que pode ser mensal ou trimestral. ${ }^{154}$

Os juros excedentes são tratados como não dedutíveis e são considerados, para os acionistas, dividendos e tributados à alíquota de $15 \%$, exceto se eventual acordo para evitar

\footnotetext{
${ }^{151}$ SHAMANOVA, Evgeniya. Ob. Cit.

${ }^{152}$ SHAMANOVA, Evgeniya. Ob. Cit.

${ }^{153}$ SHAMANOVA, Evgeniya. Ob. Cit.

${ }^{154}$ SHAMANOVA, Evgeniya. Ob. Cit.
} 
a dupla tributação celebrado entre a Rússia e o país de residência do acionista defina uma alíquota menor. $^{155}$

Cumpre notar que os juros pagos em decorrência de empréstimos destinados a complementar o capital de giro (working capital), como por exemplo, para aquisição de estoques e pagamento de salários, são integralmente dedutíveis, desde que comprovada à destinação do recurso. ${ }^{156}$

Por fim, nos tratados com cláusula de não-discriminação, as regras de subcapitalização são aplicáveis e, em que pese às autoridades fiscais não respeitarem essa determinação, os tribunais russos têm aplicado a cláusula de não-discriminação em favor dos contribuintes enquadrados nos respectivos tratados. ${ }^{157}$

Realizadas as considerações acerca da regra russa, dois elementos chamam atenção: a exceção ao princípio arm's length para empréstimos destinados à complementar o capital de giro e a proporção dívida x capital bastante elevada no caso de empresas com atividades bancárias e de leasing.

No primeiro caso, a exceção se mostra bastante inteligente, na medida em que respeita situações de capital de giro insuficiente e impede que empréstimos destinados à manutenção da atividade produtiva possam gerar juros não dedutíveis.

No que tange a proporção dívida x capital diferenciada para atividades bancárias e de leasing, a regra russa também demonstra preocupação em diferenciar a atividade específica de cada empresa e observa que faz parte da atividade principal destas empresas a intermediação financeira, realizada primordialmente mediante a tomada de recursos (muitas vezes de empresas ligadas) e repasse destes para terceiros.

\footnotetext{
155 SHAMANOVA, Evgeniya. Ob. Cit.

${ }^{156}$ SHAMANOVA, Evgeniya. Ob. Cit.

${ }^{157}$ SHAMANOVA, Evgeniya. Ob. Cit.
} 


\subsubsection{3 Índia}

De acordo com as regras indianas, os juros em geral são dedutíveis e as autoridades fiscais não têm poder para decidir se determinada empresa necessita de empréstimos ou se a taxa de juros praticada é muito elevada. ${ }^{158}$

Neste sentido, é possível a dedução de despesas com juros, ainda que não haja uma relação direta e imediata com algum retorno ou benefício.

Entretanto, algumas limitações específicas são impostas como, por exemplo, se o recurso obtido com determinado empréstimo for utilizado para aquisição de um bem a ser incorporado no ativo da companhia, os juros incorridos até que o bem seja colocado em uso não são dedutíveis e devem ser adicionados ao custo de aquisição do referido bem. ${ }^{159}$

Não há qualquer outra limitação para a dedução de juros e não há regras específicas de subcapitalização na Índia. ${ }^{160}$

Por seu turno, apesar de não haver regras tributárias específicas definindo observância de proporção fixa dívida x capital, há alguns limites regulatórios que determinam que instituições financeiras devem observar a proporção de $4: 1{ }^{161}$

Observamos que a Índia difere dos demais países analisados na medida em que há ampla liberdade para dedução de juros, não havendo qualquer limitação concernente ao princípio arm's length ou mesmo regra tributária que defina proporção fixa dívida $\mathrm{x}$ capital.

\subsubsection{Argentina}

Em que pese a Argentina não ser membro da OCDE e, portanto, não ser obrigada a adotar todos as orientações e regras impostas por esta entidade, de acordo com as regras de

\footnotetext{
${ }^{158}$ SUSARLA, Kamesh. Índia - Corporate Taxation. Sec. 1 - Country Analyses IBFD. Amsterdam, 2011. ${ }^{159}$ SUSARLA, Kamesh. Ob. Cit.

${ }^{160}$ SUSARLA, Kamesh. Ob. Cit.

${ }^{161}$ ERNST \& YOUNG. Ob. Cit., p. 474.
} 
preço de transferência argentinas, desde 1998, transações entre partes relacionadas devem ser realizadas com base no princípio arm's length, incluídos aí os juros pagos a partes relacionadas em decorrência de empréstimos. ${ }^{162}$

$\mathrm{O}$ artigo 14 do Regulamento do Imposto de Renda argentino determina que todas as transações devem observar os padrões arm's length, nos seguintes termos:

transações entre uma empresa local de capital estrangeiro e parte relacionada que a controle direta ou indiretamente devem, para todos os fins, ser equivalentes e consistentes com condições de mercado entre partes independentes, limitando empréstimos e assistência técnica. ${ }^{163}$

Além da aplicação geral do princípio arm's length, a Argentina também possui regras de subcapitalização que determinam a proporção fixa dívida x capital de 2:1 para todos os empréstimos concedidos por entidades vinculadas e sediadas no exterior. ${ }^{164}$

Caso a proporção dívida x capital seja excedida, os juros proporcionalmente excedentes serão considerados não dedutíveis e serão tratados como dividendos, o que significa dizer que não serão dedutíveis não apenas no ano do pagamento, como também nos anos futuros. ${ }^{165}$

Diferentemente do que fez China, Rússia e outros países que estabeleceram uma proporção fixa dívida x capital mais elevada para instituições financeiras, a Argentina simplesmente estabeleceu que as regras de subcapitalização não se aplicam as instituições financeiras em geral, o que parece ser uma medida acertada pois, conforme afirmamos acima, a atividade principal destas empresas é a intermediação financeira, realizada primordialmente mediante a tomada de recursos e repasse destes para terceiros e uma proporção dívida x capital muito restritiva, pode inviabilizar a atividade deste tipo de empresa.

\footnotetext{
${ }^{162}$ ERNST \& YOUNG. Ob. Cit., p. 31.

${ }^{163}$ PWC. International Transfer Pricing. Acessado em 12 de fevereiro de $2013 \mathrm{em}$ http://www.pwc.com/gx/en/international-transfer-pricing/assets/argentina.pdf

${ }^{164}$ ERNST \& YOUNG. Ob. Cit., p. 31.

${ }^{165}$ ERNST \& YOUNG. Ob. Cit., p. 31.
} 


\subsubsection{5 África do Sul}

A África do Sul estabeleceu regras de preço de transferência fundadas no princípio arm's length em 1995 e as regras de subcapitalização são parte destas regras.

A regra estabelecida em 1995 era bastante discricionária e na prática, cabia à receita federal sul-africana (conhecida como SARS) decidir quando determinada operação envolvendo uma entidade sediada na África do Sul e outra entidade sediada em outro país observou ou não o princípio arm's length. ${ }^{166}$

O principal parâmetro para a aplicação das regras de preço de transferência e de subcapitalização era encontrado nos julgados dos tribunais relativos ao conceito de despesa necessária (ou excessiva) para fins de imposto de renda, visto se tratar de conceito bastante antigo no ordenamento jurídico sul-africano e ser considerado um complemento às referidas regras. ${ }^{167}$

A ampla liberdade dada às autoridades fiscais começou a ser questionada, especialmente por usurpar os poderes do parlamento para impor a tributação, desta forma, as regras foram revistas e alteradas em 2011. ${ }^{168}$

As novas regras deixaram de ser discricionárias e as autoridades fiscais, de acordo com a nova regra, devem determinar qual preço deve ser considerado "at arm's length". 169

O conceito de pessoa vinculada foi ampliado e, de acordo com as regras expedidas em 2011, são consideradas pessoas vinculadas qualquer companhia que tenha pelo menos $20 \%$ do capital da companhia sul-africana. ${ }^{170}$

\footnotetext{
${ }^{166}$ HATTINGH, Johann. South Africa - Corporate Taxation. Sec. 1 - Country Analyses IBFD. Amsterdam, 2011.

${ }^{167}$ HATTINGH, Johann. Ob. Cit.

${ }^{168}$ HATTINGH, Johann. Ob. Cit.

${ }^{169}$ HATTINGH, Johann. Ob. Cit.

${ }^{170}$ HATTINGH, Johann. Ob. Cit.
} 
Desta forma, de acordo com as regras estabelecidas em 2011, qualquer empréstimo concedido, direta ou indiretamente, por um não residente na África do Sul estará sujeito às regras de subcapitalização quando for concedido:

a) a uma pessoa sediada na África do Sul e considerada vinculada ao não residente, nos termos acima referidos ou

b) a uma empresa sediada na África do Sul e cujo mutuante tenho direito a participar em $25 \%$ ou mais dos dividendos e lucros ou tenha $25 \%$ ou mais dos direitos de voto do mutuário. ${ }^{171}$

Adicionalmente as regras fundadas no princípio arm's length, a legislação de subcapitalização estabeleceu um safe harbour, equivalente a proporção fixa dívida $\mathrm{x}$ capital de 3:1, sem estabelecer qualquer diferenciação entre empresas financeiras e não financeiras. ${ }^{172}$

Desta forma, caso o endividamento da empresa não se enquadre no safe harbour, em outras palavras, exceda a proporção de 3:1, e a taxa de juros praticada no contrato exceda a taxa considerada arm's length (divulgada pela autoridade fiscal sul-africana), os juros proporcionalmente excedentes são considerados não dedutíveis para fins de apuração do imposto de renda.

Tendo em vista as especificidades da regra sul-africana, nos parece que, apesar de combinar os dois mecanismos de controle, safe harbour e arm's length, o que em geral indica uma regra bastante abrangente e flexível, a referida regra mostra-se bastante limitada e rígida, na medida em que aplica a mesma proporção fixa a todos as empresas, sem diferenciá-las por tipo de setor, bem como o preço ou taxa considerado como arm's length é definido pela autoridade fiscal e, neste caso, não necessariamente reflete o preço ou taxa de mercado.

\footnotetext{
${ }^{171}$ HATTINGH, Johann. Ob. Cit.

${ }^{172}$ ERNST \& YOUNG. Ob. Cit., p. 1031.
} 


\section{Antecedentes da Subcapitalização no Brasil}

Conforme dito acima, as regras de subcapitalização foram estabelecidas no Brasil recentemente $\mathrm{e}$, antes de analisarmos especificamente o texto de direito positivo, entendemos relevante a análise de seus antecedentes legislativos e jurisprudenciais, para melhor contextualização do tema.

Observamos que vários dos elementos presentes nas regras de subcapitalização recentemente estabelecidas já se encontravam no ordenamento jurídico pátrio, anteriormente a publicação da Medida Provisória $n^{\circ}$ 472/2009, caracterizando o que podemos chamar de fase pré-legislativa das regras de subcapitalização.

Nesse sentido, passamos a discorrer sobre alguns institutos anteriores à publicação da Medida Provisória $n^{\circ}$ 472/2009, identificando as semelhanças entre aqueles e as normas objeto do presente estudo, bem como sobre uma decisão verificada no âmbito administrativo, considerada uma das principais razões para o estabelecimento de regras de subcapitalização no Brasil.

Os comentários que realizaremos neste capítulo serão base de parte das críticas a serem realizados no capítulo 6, especialmente no item 6.1, quando tratarmos da (des) necessidade da norma.

4.1 Histórico das normas para a dedução de despesas financeiras antes do estabelecimento das normas de subcapitalização

Elemento relevante no âmbito das regras de subcapitalização, as despesas financeiras estiveram sujeitas ao mesmo tratamento fiscal por muitos anos e tiveram a sua dedutibilidade alterada por conta das regras estabelecidas pela Medida Provisória $\mathrm{n}^{\mathrm{0}}$ 472/2009; nesse sentido abordaremos o conceito de despesa financeira adotado pela legislação e posteriormente discorreremos acerca do tratamento fiscal destas.

Em termos conceituais, a equipe de professores da FEA/USP considerou que para fins contábeis, despesas financeiras são: despesa com juros; descontos concedidos; 
despesas e comissões bancárias; despesas e comissões sobre financiamentos; variações e correções monetárias sobre obrigações; e outras. ${ }^{173}$

Considerando o conceito denotativo apresentado pelos professores da FEA, podemos extrair um conceito conotativo de despesas financeiras: são consideradas despesas financeiras as remunerações aos capitais de terceiros, tais como juros pagos, comissões bancárias e juros de mora pagos, bem como as variações e correções monetárias sobre obrigações.

O conceito contábil de despesa financeira foi adotado pela legislação do imposto sobre a renda, como se observa no Decreto-Lei $n^{\circ} 1.598$ que, apesar de ser datado de 26 de dezembro de 1977, ainda hoje é o fundamento para muitos dispositivos relativos ao imposto sobre a renda.

Referido decreto continha um único artigo (artigo 17) no item receitas e despesas financeiras e apresentava o conceito de maneira denotativa:

Art 17 - Os juros, o desconto, a correção monetária prefixada, o lucro na operação de reporte e o prêmio de resgate de títulos ou debêntures, ganhos pelo contribuinte, serão incluídos no lucro operacional e, quando derivados de operações ou títulos com vencimento posterior ao encerramento do exercício social, poderão ser rateados pelos períodos a que competirem.

Parágrafo único - Os juros pagos ou incorridos pelo contribuinte são dedutíveis como custo ou despesa operacional, observadas as seguintes normas:

a) os juros pagos antecipadamente, os descontos de títulos de crédito, a correção monetária prefixada e o deságio concedido na colocação de debêntures ou títulos de crédito deverão ser apropriados, pro rata tempore, nos exercícios sociais a que competirem;

b) os juros de empréstimos contraídos para financiar a aquisição ou construção de bens do ativo permanente, incorridos durante as fases de construção e pré-operacional, podem ser registrados no ativo diferido, para serem amortizados.

Presentemente, o artigo 374 do Regulamento do Imposto de Renda (Decreto 3.000/99) reproduz grande parte do citado artigo 17 do Decreto-Lei 1598/77 e continua a ser, no regulamento do imposto de renda, o único artigo do item despesas financeiras.

Assim dispõe o artigo 374, que está situado no capítulo relativo ao lucro operacional, na seção outros resultados operacionais:

\footnotetext{
${ }^{173}$ Equipe de Professores da FEA/USP. Contabilidade Introdutória. São Paulo: Atlas, 1998, p. 161.
} 
Art. 374. Os juros pagos ou incorridos pelo contribuinte são dedutíveis, como custo ou despesa operacional, observadas as seguintes normas (Decreto-Lei $\mathrm{n}^{\circ}$ 1.598, de 1977, art. 17, parágrafo único):

I - os juros pagos antecipadamente, os descontos de títulos de crédito, e o deságio concedido na colocação de debêntures ou títulos de crédito deverão ser apropriados, pro rata temporis, nos períodos de apuração a que competirem;

II - os juros de empréstimos contraídos para financiar a aquisição ou construção de bens do ativo permanente, incorridos durante as fases de construção e pré-operacional, podem ser registrados no ativo diferido, para serem amortizados.

Parágrafo único. Não serão dedutíveis na determinação do lucro real, os juros, pagos ou creditados a empresas controladas ou coligadas, domiciliadas no exterior, relativos a empréstimos contraídos, quando, no balanço da coligada ou controlada, constar a existência de lucros não disponibilizados para a controladora ou coligada no Brasil (Lei ${ }^{\circ} 9.532$, de 1997, art. $1^{\circ}, \S 3^{\circ}$ ).

Adicionalmente ao artigo 374 do Regulamento do Imposto de Renda, observamos que o artigo $9^{\circ}$ da Lei ${ }^{\circ} 9.718$, de 27 de novembro de 1998 assim determinou:

Art. $9^{\circ}$ As variações monetárias dos direitos de crédito e das obrigações do contribuinte, em função da taxa de câmbio ou de índices ou coeficientes aplicáveis por disposição legal ou contratual serão consideradas, para efeitos da legislação do imposto de renda, da contribuição social sobre o lucro líquido, da contribuição PIS/PASEP e da COFINS, como receitas ou despesas financeiras, conforme o caso.

Conjugando-se os artigos 374 do Regulamento do Imposto de Renda e o artigo $9^{\circ}$ da Lei $n^{\circ}$ 9.718/98 acima reproduzidos, observamos que a legislação do imposto sobre a renda seguiu o conceito contábil de despesa financeira e a equiparou aos juros e variações monetárias dos direitos de crédito e das obrigações.

Definido o conceito de despesa financeira, passamos a analisar o tratamento fiscal atribuído a essas despesas anteriormente ao estabelecimento das regras de subcapitalização.

Tivemos a oportunidade de abordar as conseqüências fiscais dos juros nos contratos de empréstimos de maneira bastante abrangente no item 2.2.3 e o raciocínio lógico para dedução das demais despesas financeiras (variações monetárias dos direitos de crédito e obrigações) é bastante semelhante ao adotado no referido item.

Nos termos do art. 299 do Regulamento do Imposto de Renda, somente será dedutível na apuração do imposto de renda, a despesa necessária à atividade da empresa e a fonte produtora de receitas e usual ou normal no tipo de operações ou atividades da empresa. 
Determina o citado artigo:

Art. 299. São operacionais as despesas não computadas nos custos, necessárias à atividade da empresa e à manutenção da respectiva fonte produtora (Lei nº 4.506, de 1964, art. 47).

$\S 1^{\circ}$ São necessárias as despesas pagas ou incorridas para a realização das transações ou operações exigidas pela atividade da empresa (Lei no 4.506, de 1964, art. 47, § $1^{\circ}$ ).

$\S 2^{\circ}$ As despesas operacionais admitidas são as usuais ou normais no tipo de transações, operações ou atividades da empresa (Lei ${ }^{\circ} 4.506$, de 1964, art. 47, $\S 2^{\circ}$ ).

$\S 3^{\circ} \mathrm{O}$ disposto neste artigo aplica-se também às gratificações pagas aos empregados, seja qual for a designação que tiverem.

Ante a redação acima reproduzida, temos que qualquer despesa, para ser considerada dedutível, deve se amoldar, inicialmente, ao conceito trazido pelo artigo 299 do Decreto $n^{\circ} 3.000 / 99$. Por decorrência lógica, referida regra também é aplicável as despesas financeiras.

Ricardo Mariz de Oliveira reproduz as lições de Hugo de Brito Machado quando se manifestou sobre os limites do poder legislativo na imposição de restrições à dedutibilidade de custos e despesas:

"Na determinação do valor da renda tributável devem ser considerados, isto sim, os seguintes aspectos:

a) Efetividade - as despesas devem ser verdadeiras, isto é, devem ter essa natureza econômica, e não devem acobertar práticas evasivas, fraudulentas ou não.

b) Pertinência - as despesas devem ser pertinentes, posto que as despesas admitidas são as usuais e normais no tipo de transações, operações ou atividades da empresa. Como usuais ou normais devem ser entendidas aquelas que sejam uma contingencia de atividade ou a ela inerentes, e não somente aquelas que decorram de um desempenho lícito de atividade, posto que no Direito Tributário essa licitude é irrelevante". ${ }^{174}$

Arremata Ricardo Mariz de Oliveira que o essencial, portanto, é que as despesas tenham relação de pertinência com as atividades da pessoa jurídica. ${ }^{175}$

Tendo em vista os comentários acima, pode-se afirmar que não havia regra específica para a dedução de despesas financeiras antes do estabelecimento das normas de subcapitalização (exceção feita aos juros, conforme abordado no item 2.2.3), existindo apenas regra geral e abrangente que vinculava a dedutibilidade destas despesas ao fato

\footnotetext{
${ }^{174}$ MACHADO, Hugo de Brito, “A supremacia constitucional e o imposto de renda”, estudos sobre o imposto de renda - em memória de Henry Tilbery. Editora Resenha Tributária, 1994, p. 56 in OLIVEIRA, Ricardo Mariz de. Ob. Cit. p. 712.

${ }^{175}$ OLIVEIRA, Ricardo Mariz de. Ob. Cit. p. 713.
} 
destas serem necessárias à atividade da empresa e a fonte produtora de receitas, assim entendidas as despesas usuais ou normais ao tipo de operações ou atividades da empresa.

Uma busca rápida na doutrina e jurisprudência administrativa e judicial demonstra que o tema 'despesa necessária' já foi objeto de muito debate; por outro lado, grande parte dos comentários e discussões segue a linha dos comentários de Ricardo Mariz de Oliveira: o essencial para a dedutibilidade das despesas financeiras é que as despesas tenham relação de pertinência com as atividades da pessoa jurídica.

Desta forma, antes das regras de subcapitalização, o intérprete e aplicador da lei deveriam analisar o fato que tinha dado origem a despesa financeira e verificar objetivamente se ele se relacionava com a atividade da empresa ou com a sua fonte produtora. Se a resposta fosse positiva, ele deveria admitir que a despesa era necessária, e portanto, dedutível para fins de apuração do imposto de renda e da contribuição social sobre o lucro líquido. ${ }^{176}$

Por outro lado, com o estabelecimento das regras de subcapitalização, um novo elemento foi adicionado às discussões, conforme veremos no capítulo 5.

4.2 Distribuição disfarçada de lucros - DDL

As regras relativas à distribuição disfarçada de lucros - DDL foram estabelecidas inicialmente na Lei $n^{\circ} 4.506$ de 30 de novembro de 1964 e veio a ganhar os contornos atuais com a publicação do já citado Decreto-Lei $n^{\circ} 1.598 / 77$ (artigos no 60 a 62) e Decreto-Lei 2.065/83 (artigos n ${ }^{\circ} 20$ e 21). A sua consolidação encontra-se, presentemente, no artigo 464 e seguintes do Decreto n $3.000 / 99$ - Regulamento do Imposto de Renda que assim dispõe:

Art. 464. Presume-se distribuição disfarçada de lucros no negócio pelo qual a pessoa jurídica (Decreto-Lei $\mathrm{n}^{\circ}$ 1.598, de 1977, art. 60, e Decreto-Lei n ${ }^{\circ}$ 2.065, de 1983, art. 20, inciso II):

I - aliena, por valor notoriamente inferior ao de mercado, bem do seu ativo a pessoa ligada;

II - adquire, por valor notoriamente superior ao de mercado, bem de pessoa ligada;

III - perde, em decorrência do não exercício de direito à aquisição de bem e em benefício de pessoa ligada, sinal, depósito em garantia ou importância paga para obter opção de aquisição;

${ }^{176}$ OLIVEIRA, Ricardo Mariz de. Ob. Cit. p. 714. 
IV - transfere a pessoa ligada, sem pagamento ou por valor inferior ao de mercado, direito de preferência à subscrição de valores mobiliários de emissão de companhia;

V - paga a pessoa ligada aluguéis, royalties ou assistência técnica em montante que excede notoriamente ao valor de mercado;

VI - realiza com pessoa ligada qualquer outro negócio em condições de favorecimento, assim entendidas condições mais vantajosas para a pessoa ligada do que as que prevaleçam no mercado ou em que a pessoa jurídica contrataria com terceiros.

$\S 1^{\circ} \mathrm{O}$ disposto nos incisos I e IV não se aplica nos casos de devolução de participação no capital social de titular, sócio ou acionista de pessoa jurídica em bens ou direitos, avaliados a valor contábil ou de mercado (Lei $\mathrm{n}^{\circ}$ 9.249, de 1995, art. 22).

$\S 2^{\circ}$ A hipótese prevista no inciso II não se aplica quando a pessoa física transferir a pessoa jurídica, a título de integralização de capital, bens e direitos pelo valor constante na respectiva declaração de bens (Lei n 9.249, de 1995, art. 23, § $1^{\circ}$ ).

$\S 3^{\circ}$ A prova de que o negócio foi realizado no interesse da pessoa jurídica e em condições estritamente comutativas, ou em que a pessoa jurídica contrataria com terceiros, exclui a presunção de distribuição disfarçada de lucros (Decreto-Lei no 1.598 , de 1977, art. 60, § $2^{\circ}$ ).

Após a definição da distribuição disfarçada de lucros propriamente dita, realizada pelo art. 464 do Regulamento do Imposto sobre a Renda, o artigo 465 do mesmo dispositivo legal traz esclarecimentos quanto aos conceitos de pessoa ligada, valor de mercado e valor do bem negociado freqüentemente no mercado. ${ }^{177}$

Adicionalmente a essas disposições, observamos ainda que o art. 60 da Lei 9.532/97 determina que o valor dos lucros distribuídos disfarçadamente será, também, adicionado ao lucro líquido para efeito de determinação da base de cálculo da contribuição social sobre o lucro líquido.

Analisando os dispositivos reproduzidos e citados acima, Ricardo Mariz de Oliveira observa que as regras de DDL visam evitar a passagem de lucros da pessoa jurídica para

${ }^{177}$ Art. 465. Considera-se pessoa ligada à pessoa jurídica (Decreto-Lei $n^{\circ} 1.598$, de 1977, art. 60, $\S 3^{\circ}$, e Decreto-Lei $\mathrm{n}^{\circ} 2.065$, de 1983, art. 20, inciso IV):

I - o sócio ou acionista desta, mesmo quando outra pessoa jurídica;

II - o administrador ou o titular da pessoa jurídica;

III - o cônjuge e os parentes até o terceiro grau, inclusive os afins, do sócio pessoa física de que trata o inciso I e das demais pessoas mencionadas no inciso II.

$\S 1^{\circ}$ Valor de mercado é a importância em dinheiro que o vendedor pode obter mediante negociação do bem no mercado (Decreto-Lei $n^{\circ} 1.598$, de 1977, art. 60, $\S 4^{\circ}$ ).

$\S 2^{\circ} \mathrm{O}$ valor do bem negociado freqüentemente no mercado, ou em bolsa, é o preço das vendas efetuadas em condições normais de mercado, que tenham por objeto bens em quantidade e em qualidade semelhantes (Decreto-Lei n ${ }^{\circ} 1.598$, de 1977, art. 60, $\S 5^{\circ}$ ).

$\S 3^{\circ} \mathrm{O}$ valor dos bens para os quais não haja mercado ativo poderá ser determinado com base em negociações anteriores e recentes do mesmo bem, ou em negociações contemporâneas de bens semelhantes, entre pessoas não compelidas a comprar ou vender e que tenham conhecimento das circunstâncias que influam de modo relevante na determinação do preço (Decreto-Lei $\mathrm{n}^{\circ} 1.598$, de 1977, art. 60, § $6^{\circ}$ ).

$\S 4^{\circ}$ Se o valor do bem não puder ser determinado nos termos dos $\S \S 2^{\circ}$ e $3^{\circ}$ e o valor negociado pela pessoa jurídica basear-se em laudo de avaliação de perito ou empresa especializada, caberá à autoridade tributária a prova de que o negócio serviu de instrumento à distribuição disfarçada de lucros (Decreto-Lei n ${ }^{\circ} 1.598$, de 1977 , art. $\left.60, \S 7^{\circ}\right)$. 
pessoa ou pessoas a ela ligadas, mediante preços ou condições de negócios que sejam diferentes de preços ou das condições que são praticados por pessoas não ligadas, ou mesmo em certos atos que normalmente não seriam praticados entre partes independentes. ${ }^{178}$

Na opinião do autor, a lei visa, no interesse da arrecadação tributária, impedir a transferência de lucros da pessoa jurídica para pessoas a ela vinculadas, mediante preços que teoricamente não seriam praticados entre pessoas não vinculadas, e também usa mecanismos de sanção da pessoa jurídica autora da transferência, mediante ajustes no seu lucro líquido que acarretam acréscimo ao seu lucro tributável e, consequentemente, aumento do imposto de renda devido pela pessoa jurídica. ${ }^{179}$

De maneira geral, se pode afirmar que as hipóteses hoje vigentes de DDL, buscam a aplicação do princípio arm's length, na medida em que visam à prática de preços e condições de mercado nas relações entre partes relacionadas, determinando a aplicação às regras de DDL de princípio largamente utilizado nas legislações que tratam da subcapitalização em todo o mundo, como relatamos no item 3.2.

Como veremos no capítulo 5, a legislação brasileira de subcapitalização não adotou o princípio arm's length, pois referidas regras buscaram estabelecer limites e parâmetros objetivos para a relação entre partes relacionadas/vinculadas, se aproximando mais das regras de safe harbour.

Em uma linha um pouco diferente dos dispositivos que buscam a aplicação direta do princípio arm's length, Ricardo Mariz de Oliveira observa ainda que havia outra hipótese de DLL prevista em lei, mas que ficou tacitamente revogada pela Lei $\mathrm{n}^{\circ}$ 9.249, quando esta extinguiu a correção monetária das demonstrações financeiras. Essa hipótese equiparava à distribuição disfarçada de lucros o empréstimo de dinheiro pela pessoa jurídica à pessoa ligada, se, nesta data, a pessoa jurídica possuísse lucros acumulados ou reservas de lucros. ${ }^{180}$

\footnotetext{
${ }^{178}$ OLIVEIRA, Ricardo Mariz de. Ob. Cit. p. 775.

${ }^{179}$ OLIVEIRA, Ricardo Mariz de. Ob. Cit. p. 775.

${ }^{180}$ OLIVEIRA, Ricardo Mariz de. Ob. Cit. p. 789.
} 
A hipótese citada por Ricardo Mariz de Oliveira estava prevista no artigo 60 do Decreto-Lei no 1.598 , com redação dada pelo Decreto-Lei $n^{\circ}$ 2.065/1983:

Art 60 - Presume-se distribuição disfarçada de lucros no negócio pelo qual a pessoa jurídica:

(...)

V - empresta dinheiro a pessoa ligada se, na data do empréstimo, possui lucros acumulados ou reservas de lucros;

(...)

$\S 1^{\circ} \mathrm{O}$ disposto no item $\mathrm{V}$ não se aplica às operações de instituições financeiras, companhias de seguro e capitalização e outras pessoas jurídicas, cujo objeto sejam atividades que compreendam operações de mútuo, adiantamento ou concessão de crédito, desde que realizadas nas condições que prevaleçam no mercado, ou em que a pessoa jurídica contrataria com terceiros.

Nessa hipótese de DDL, o valor total do empréstimo era considerado distribuição disfarçada e deveria ser deduzido dos lucros acumulados ou reserva de lucros, exceto a legal, para efeito de correção monetária do patrimônio líquido. Neste sentido, a revogação tácita desta hipótese decorreu da extinção da correção monetária.

Desta forma, ainda que ocorra hoje essa situação fática que até 1995 caracterizava DDL, não há mais como aplicar a normatização desta, cabendo outros tipos de indagações, por exemplo, se a pessoa jurídica está tomando dinheiro emprestado para repassá-lo à pessoa ligada, sem repassar a esta os encargos do empréstimo que tomou, caso em que a despesa com tais encargos não será dedutível, por não se referir às atividades da empresa que registrou a despesa. ${ }^{181}$

Interessante observar que em tese publicada em 1996, que lhe garantiu a livredocência pela Faculdade de Direito da USP, Luís Eduardo Schoueri, ao tratar da hipótese de DDL nos empréstimos de dinheiro pela pessoa jurídica à pessoa ligada, observou que um critério interessante extraído da jurisprudência alemã e que não havia encontrado reflexo no direito brasileiro (à época da publicação do livro) era o montante do empréstimo em relação ao patrimônio da pessoa jurídica. ${ }^{182}$

Em outras palavras, Luís Eduardo Schoueri, ao tratar de Distribuição Disfarçada de Lucros em 1996, demonstrou de maneira incidental, um dos precedentes e fundamentos das regras de subcapitalização estabelecidas no Brasil apenas em 2009.

\footnotetext{
${ }^{181}$ OLIVEIRA, Ricardo Mariz de. Ob. Cit. p. 790.

${ }^{182}$ SCHOUERI, Luís Eduardo. Distribuição Disfarçada de Lucros. São Paulo: Dialética, 1996, p. 63
} 
4.3 Estímulo à capitalização das empresas - Juros sobre o capital próprio

Veremos no capítulo 5 que segundo a exposição de motivos que acompanhou a Medida Provisória n 472/09, as normas para evitar a subcapitalização visam, dentre outras coisas, o estímulo para capitalização das empresas.

Por seu turno, anteriormente ao estabelecimento das regras para evitar a subcapitalização, outras medidas tendentes a estimular a capitalização de empresas já haviam sido adotadas no país.

Podemos destacar, dentre essas medidas, a introdução no ordenamento jurídico pátrio dos juros sobre o capital próprio, em 1995.

Neste ponto, analisaremos de maneira objetiva o texto de direito positivo e brevemente as razões para o estabelecimento da citada medida, que evidencia claramente a preocupação do legislador com a capitalização das empresas.

Após a breve análise realizada neste capítulo, destinada apenas a contextualização do tema, realizaremos, no item 6.1.2, análise detalhada do instituto dos juros sobre o capital próprio, confrontando com as regras de subcapitalização e, em última análise, verificando a pertinência das últimas, vis-à-vis a existência prévia do referido instituto no ordenamento jurídico brasileiro.

A figura dos juros sobre o capital próprio foi introduzida no ordenamento pátrio pela Lei $\mathrm{n}^{\circ} 9.249$, de 26 de dezembro de 1995, que dispunha em seu artigo $9^{\circ}$ :

Art. $9^{\circ}$ A pessoa jurídica poderá deduzir, para efeitos da apuração do lucro real, os juros pagos ou creditados individualizadamente a titular, sócios ou acionistas, a título de remuneração do capital próprio, calculados sobre as contas do patrimônio líquido e limitados à variação, pro rata dia, da Taxa de Juros de Longo Prazo - TJLP.

$\S 1^{\circ} \mathrm{O}$ efetivo pagamento ou crédito dos juros fica condicionado à existência de lucros, computados antes da dedução dos juros, ou de lucros acumulados e reservas de lucros, em montante igual ou superior ao valor de duas vezes os juros a serem pagos ou creditados.

$\S 2^{\circ}$ Os juros ficarão sujeitos à incidência do imposto de renda na fonte à alíquota de quinze por cento, na data do pagamento ou crédito ao beneficiário.

(...) 
Como se observa do texto legal, a partir de 1996, as pessoas jurídicas foram autorizadas a deduzir da apuração do imposto de renda e da contribuição social sobre o lucro líquido, remuneração paga aos sócios ou acionistas, sendo essa remuneração calculada com a aplicação da taxa de juros de longo prazo - TJLP sobre o patrimônio líquido, ficando a dedutibilidade desta remuneração, chamada de juros sobre o capital próprio, limitada a existência de lucros acumulados e reserva de lucros ou existência de lucros no período de pagamento em montante igual ou superior a duas vezes os juros a serem pagos ou creditados.

A razão para o estabelecimento da regra citada acima foi explicitada nos itens 10 e 11 da exposição de motivos do projeto de lei que resultou na Lei $n^{\circ}$ 9.249/95:

10- Com vistas a equilibrar a tributação dos diversos tipos de rendimentos do capital, o Projeto introduz a possibilidade de remuneração do capital próprio investido na atividade produtiva, permitindo a redução dos juros pagos ao acionista, até o limite da variação da Taxa de Juros de Longo Prazo - TJLP; (...)

11 - a permissão da dedução de juros pagos ao acionista, até o limite proposto, em especial, deverá provocar um incremento das aplicações produtivas nas empresas brasileiras, capacitando-as a elevar o nível de investimentos, sem endividamento, com evidentes vantagens no que se refere à geração de empregos e ao crescimento sustentado da economia. Objetivo a ser atingido mediante a adoção de política tributária moderna e compatível com aquela praticada pelos demais países emergentes, que competem com o Brasil na captação de recursos internacionais para investimento.

A simples leitura da exposição de motivos evidência o principal motivo do estabelecimento dos juros sobre o capital próprio: trata-se de medida tendente a estimular a capitalização de empresas e diminuir o nível de endividamento.

Interessante observar que a exposição de motivos não relega aos juros sobre capital próprio a "missão" de ser o único elemento propulsor da capitação de investimentos, mas faz interessante observação no sentido de que o objetivo de capitalização de empresas com vistas à geração de empregos e ao crescimento sustentado da economia deve ser atingido mediante a adoção de política tributária moderna e compatível com aquela praticada pelos demais países emergentes.

Em complemento à exposição de motivos, observamos novamente a característica de estímulo à capitalização das pessoas jurídicas no relatório apresentado pelo Deputado Antônio Kandir, relator do parecer da Comissão de Finanças e Tributação: 
A medida visa a estimular o autofinanciamento das empresas, pela redução da diferença de tratamento que a atual legislação confere ao capital próprio e ao capital de terceiros. Como se sabe, os juros sobre empréstimos (capital de terceiros) são dedutíveis na determinação da base de cálculo do Imposto de renda, enquanto os encargos implícitos sobre a parcela do capital próprio não podem ser deduzidos.

Com isso, a empresa que se financia de forma preponderante com empréstimos de terceiros tem a vantagem comparativa com outra empresa do mesmo porte, que opere no mesmo setor, mas que prefira financiar-se com capital próprio, pois que a primeira deverá pagar menos Imposto de renda do que a segunda. (...) Os encargos implícitos sobre o capital próprio consistem no seu custo de oportunidades, vale dizer, no custo equivalente ao quanto renderia se aplicado no mercado financeiro.

Como se observa tanto na exposição de motivos, quanto no relatório do Deputado Antônio Kandir, a intenção do governo, ao editar a Lei $n^{\circ}$ 9.249/95, foi a busca de capital (equity) para as pessoas jurídicas aqui estabelecidas, ao invés de dívida (debit), por entender que essa estrutura propiciaria benefícios para a atividade produtiva do país, e buscou o incentivo por meio de medida que equiparou o tratamento tributário aplicável aos custos de financiamentos por meio de empréstimos e a remuneração dos titulares, sócios ou acionistas realizada por meio dos juros sobre capital próprio.

Em que pese a exposição de motivos e o relatório do Deputado Antônio Kandir dar a entender que se trata de questão de fácil resolução e que poderia ser fator determinante para a capitalização das empresas por meio de equity e não debit, a questão não se revela simples e motivou Walter Lee Ness Junior e João Zani a escreverem artigo com o título: "os juros sobre o capital próprio versus a vantagem fiscal do endividamento", onde os autores buscaram verificar até que ponto a introdução dos juros remuneratórios sobre o capital próprio reduziu a vantagem fiscal do endividamento. ${ }^{183}$

Relatam os autores que "em princípio, as teorias sobre a estrutura de capital admitem vantagem fiscal da dívida em relação ao capital próprio. A inovação de atribuir despesas de juros sobre o capital próprio sugere que não são mais válidos, em sua plenitude, os argumentos favoráveis à dívida". ${ }^{184}$

Assim, após uma série de cálculos matemáticos (visto que não se trata de artigo jurídico) para avaliar se a opção por pagar juros sobre o capital próprio representaria ou não vantagem fiscal em relação à estrutura dívida, os autores concluíram que seria mais

\footnotetext{
${ }^{183}$ NESS JUNIOR, Walter Lee; ZANI, João. Os juros sobre o capital próprio versus a vantagem fiscal do endividamento. Revista de Administração, v. 36, nº 2, abr./jun. 2001, p. 89.

${ }^{184}$ NESS JUNIOR, Walter Lee; ZANI, João. Ob. Cit., p. 93.
} 
vantajoso para a empresa operar apenas com capital próprio, especialmente quando considerados eventuais custos de falência.

Verificamos que o estudo de Walter Lee Ness Junior e João Zani reforça as observações constantes da exposição de motivos que acompanharam o projeto de Lei que veio a resultar na Lei $\mathrm{n}^{\circ} 9.249 / 95$, no sentido de que a capitalização de empresas com vistas à geração de empregos e ao crescimento sustentado da economia deve ser atingida mediante a adoção de política tributária abrangente.

Por outro lado, o estabelecimento dos juros sobre o capital próprio representou grande avanço neste campo, especialmente por mudar a premissa geralmente adotada (antes da introdução de referida figura no ordenamento pátrio) que o debit é sempre mais vantajoso que o equity.

4.4 Julgamento do Conselho de Contribuintes - caso "Colgate / Kolynos" 185 - análise da relevância para o entendimento da matéria.

Discorremos acerca do conceito e tratamento fiscal das despesas financeiras, previamente ao estabelecimento das regras de subcapitalização, no item 4.1.

Por outro lado, além do plano legislativo abordado na referido item, mostra-se relevante também a análise de acórdão do antigo conselho de contribuintes conhecido como caso Colgate/Kolynos, julgamento este considerado como um dos principais motivos para o estabelecimento das regras de subcapitalização no Brasil e que tratou em detalhes do tema despesas financeiras e debateu se havia, no plano jurídico vigente à época da decisão, limitação ao endividamento.

Elidie Bifano segue a mesma linha e afirma que a subcapitalização, mesmo antes de regulada, foi objeto de análise pelos tribunais administrativos que decidiram, em sua opinião, de forma equivocada em alguns casos como, por exemplo, no caso Colgate/Kolynos, onde ficou consignado que a sociedade estrangeira tinha a opção de

\footnotetext{
${ }^{185}$ http://carf.fazenda.gov.br/sincon/public/pages/ConsultarJurisprudencia/listaJurisprudenciaCarf.jsf
} 
investir recursos sob a forma de capital e não o fez e, portanto, as despesas com o pagamento de juros decorrentes de empréstimos deveriam ser considerados indedutíveis. ${ }^{186}$

Como podemos observar no relatório do acórdão $\mathrm{n}^{\mathrm{o}}$ 101-95.014 do Primeiro Conselho de Contribuintes, datado de 16 de novembro de 2005, o caso conhecido como "Colgate / Kolynos" teve início com auto de infração lavrado contra a empresa Kolynos do Brasil S.A (nova razão social de Colgate Palmolive Indústria e Comércio Ltda.), mediante o qual foi formalizada exigência de imposto de renda da pessoa jurídica e da contribuição social sobre o lucro líquido relativa aos anos-calendário de 1996, 1997 e 1998.

O auto de infração se fundava na glosa de despesas pela falta de comprovação da efetividade e da necessidade real dos dispêndios a título de despesa financeira e variação cambial passiva incidentes sobre empréstimo no valor de 496.279.069,77 dólares americanos (USD), relacionado com a aquisição da Kolynos do Brasil Ltda. (antiga K\&S Aquisições Ltda.).

O relatório do acórdão do Conselho de Contribuintes reproduz parte do auto de infração que descreve todas as etapas da operação que deram origem ao referido empréstimo e conclui que as diversas etapas da aquisição implicaram, na prática, na concessão de um empréstimo de USD 760 milhões, que foi parcialmente integralizado como capital (USD 263 milhões), remanescendo dívida de USD 496 milhões.

Segundo a fiscalização, o empréstimo de USD 496 milhões foi mantido por questões tributárias, pois influencia diretamente o resultado do exercício, na medida em que todos os encargos decorrentes do pagamento do empréstimo são deduzidos do lucro líquido e conseqüentemente do lucro real, pois são contabilizados como despesa financeira.

Desta forma, a fiscalização concluiu que nos anos-calendário de 1996, 1997 e 1998 a empresa infringiu o disposto no artigo 242 do Regulamento do Imposto de Renda de 1994 (atual artigo 299 do Regulamento de 1999), resultando em matéria tributável a título de "custo, despesas operacionais e encargos não necessários".

\footnotetext{
${ }^{186}$ BIFANO, Elidie Palma. Estruturações de operações no mercado financeiro e o tema do planejamento tributário. In: MOSQUERA, Roberto Quiroga (coord.). O direito tributário e o mercado financeiro e de capitais. São Paulo: Dialética, 2010. v.2, p. 145.
} 
Em resposta (via impugnação), a empresa esclareceu que todas as etapas do processo tiveram como objetivo a manutenção de estruturas organizacionais distintas entre Brasil e Estados Unidos por questão de conveniência e flexibilidade, em face de eventuais futuras transações ou reorganizações.

Esclareceu ainda a empresa que o negócio foi efetivado no exterior porque o grupo, ciente de que a legislação do imposto de renda em vigor não tributava os ganhos de capital auferidos na alienação de investimentos em sociedade estrangeira, houve por bem vender o seu investimento no exterior e assim obter lícita economia fiscal, como de fato obteve, tanto que, autuada pela Receita Federal, por não pagamento de imposto de renda sobre o lucro auferido na operação, a empresa brasileira foi exonerada da exigência por decisão unânime da $1^{\circ}$ turma do $1^{\circ}$ Conselho de Contribuintes.

Ponderou também a autuada que são muitas as formas legítimas pelas quais uma empresa pode contrair uma dívida, e se a dívida contraída prestou-se aos interesses da empresa, convergindo diretamente à manutenção e ao desenvolvimento de suas atividades, os encargos dela resultantes são operacionais e, portanto, dedutíveis na determinação do lucro real, independentemente de qual tenha sido a forma de contratação.

Ao esclarecer a questão do empréstimo versus a capitalização, a empresa alegou em sua defesa que o empréstimo de dinheiro de empresa não residente à empresa domiciliada no país configura negócio jurídico lícito e sua realização é extremamente comum entre empresas vinculadas. Alegou ainda que existe o principio da autonomia de vontade em matéria contratual e que o único limite para a realização do empréstimo se refere aos juros, relativamente às regras de preço de transferência e, neste ponto, à fiscalização não encontrou qualquer violação ao artigo 22 da Lei no 9.430/96.

No voto vencedor do acórdão $\mathrm{n}^{\mathrm{o}}$ 101-95.014 do Primeiro Conselho de Contribuintes, formulado pelo conselheiro Mário Junqueira Franco Júnior, há menção expressa que a opção de financiamento utilizada pela controlada no exterior não fere em nada a legislação tributária, principalmente porque não há (à época do julgamento) no Brasil qualquer regra de limitação de dedutibilidade de encargos de financiamento pelo 
próprio sócio com relação à denominada "thin capitalization" ou subcapitalização, como ocorre na Comunidade Européia ou no México.

Como conclusão do seu voto, o conselheiro julgou procedente o recurso voluntário apresentado pela empresa, cancelando o auto de infração, pelos seguintes motivos: 1) a efetividade do empréstimo contraído, 2) a natureza exclusiva de condução das operações no Uruguai em razão do objetivo do vendedor; 3) a inexistência de regra jurídica específica para limitação de dedutibilidade em casos de subcapitalização, 4) a possibilidade jurídica de uma empresa nacional contrair empréstimos de sua controladora no exterior e 5) a tributação dos encargos desse empréstimo no momento do crédito ou pagamento.

Em resposta ao julgamento do $1^{\circ}$ Conselho de Contribuintes, a Procuradoria da Fazenda Nacional - PFN apresentou recurso à Câmara Superior de Recursos Fiscais, ocorrendo o julgamento em 24 de agosto de 2009 (acórdão no 101-138.101), 4 meses antes da publicação da Medida Provisório n 472, que estabeleceu as regras de subcapitalização no Brasil, situação está que nos leva a crer que este julgamento foi fundamental para o estabelecimento das regras de subcapitalização no Brasil.

A procuradoria argumentou em seu recurso que a despesa não era necessária e que o empréstimo não decorreu de um ato de gestão da recorrida, mas de imposição do controlador, fato este que reduziu a capacidade de geração de lucro da recorrida. Argumenta ainda que houve ato anormal de gestão.

No voto da conselheira relatora Adriana Gomes Rêgo ficou consignado que os dados financeiros da empresa ligada no exterior, que concedeu o empréstimo à empresa brasileira, demonstravam que havia capacidade de integralização de capital o que, segundo a relatora, demonstrava que o empréstimo não era necessário à atividade da empresa.

Interessante notar que na opinião da relatora, muito embora em 1996 (portanto, após a tomada de decisão dos empréstimos em 1995), a legislação tenha autorizado a dedução de juros sobre o capital próprio, tal fato não tem o condão de equalizar os efeitos tributários advindos de uma eventual capitalização, pois os empréstimos em comento 
proporcionaram, durante um longo período, não só a dedução de juros, sem qualquer limitação legal, como também a dedução de variação cambial.

Pontuou ainda a relatora que efetivamente no Brasil não havia regras sobre coeficiente de endividamento admissível ou safe haven; no entanto, outras regras específicas à legislação do Imposto de Renda que precisavam ser analisadas, especialmente se as despesas em comento atendiam aos requisitos de necessidade, usualidade e normalidade o que, em seu entender, não se observou no caso em discussão no tocante à necessidade, pois, por liberalidade das partes envolvidas, adotou-se a forma de empréstimos em detrimento da capitalização.

Desta forma, a relatora deu provimento ao recurso da PFN e reconheceu como devidas as exigências de Imposto de Renda da Pessoa Jurídica relativas a despesas não necessárias, sendo esse o resultado final do julgamento por voto de qualidade o que, em outras palavras, significa que houve empate na votação e o caso foi decidido com o voto de minerva do presidente da Câmara Superior de Recursos Fiscais, representante da fazenda.

A narrativa acima evidência que se trata de um caso bastante complexo e que teve intenso debate nos órgãos administrativos de julgamento, debates estes que tocaram em pontos cruciais para o entendimento da matéria, tais como: despesas necessárias, limitação de juros, juros sobre capital próprio x subcapitalização, etc.

Tendo em vista a estrutura de exposição adotada, os pontos referidos acima serão explorados no capítulo 6.1, quando trataremos da (des) necessidade das regras de subcapitalização. 
Como dissemos linhas atrás, até o ano de 2009, não existiam limites à dedução de juros em empréstimos no plano legal pátrio. ${ }^{187} 188$

Por seu turno, em 16 de dezembro de 2009, foi publicada no diário oficial a Medida Provisória n 472 que, dentre inúmeras matérias, dispôs sobre os limites de dedutibilidade dos juros na apuração do lucro real e da base de cálculo da contribuição social sobre o lucro líquido, surgindo assim, as primeiras regras de subcapitalização no Brasil. ${ }^{189}$

Segundo a exposição de motivos que acompanhou a Medida Provisória $\mathrm{n}^{\circ}$ $472 / 09^{190}$, mais do que impor limites à dedutibilidade dos juros na apuração do lucro real e da base de calculo da contribuição social sobre o lucro líquido, as normas brasileiras contra a subcapitalização visaram evitar a erosão da base de cálculo dos referidos tributos mediante endividamento abusivo.

\footnotetext{
${ }^{187}$ Exceção feita à limitação de juros pagos a pessoas vinculadas, contida no artigo 22 da Lei no 9.430/96, estabelecida no âmbito das regras de preço de transferência, onde se definiu que a dedutibilidade de juros pagos a pessoas vinculadas estava limitada ao valor calculado com base na taxa Libor para depósitos em dólares dos Estados Unidos da América pelo prazo de seis meses, acrescida de spread a ser definido pelo Ministro da Fazenda.

${ }^{188}$ Importante observar que as regras de preço de transferência referidas na nota 187 não serão objeto de comentário específicos no presente trabalho.

${ }^{189}$ SANTI, Eurico Marcos Diniz de e CANADO, Vanessa Rahal. Vigência e Eficácia das Novas Regras de Subcapitalização. Revista Dialética de Direito Tributário no 192. São Paulo: Dialética, 2011, p. 10.

${ }^{190} 29$. O art. 24 visa evitar a erosão da base de cálculo do IRPJ e da CSLL mediante o endividamento abusivo realizado da seguinte forma: a pessoa jurídica domiciliada no exterior, ao constituir subsidiária no País, efetua uma capitalização de valor irrisório, substituindo o capital social necessário à sua constituição e atuação por um empréstimo, que gera, artificialmente, juros que reduzem os resultados da subsidiária brasileira.

29.1. A dedução desses juros da base de cálculo do IRPJ (alíquota de 15\% mais adicional de 10\%) e da CSLL (alíquota de 9\%) gera uma economia tributária de 34\% do seu valor. Mesmo considerando que as remessas para pagamento de juros são tributadas pelo Imposto sobre a Renda Retido na Fonte (IRRF) à alíquota de $15 \%$, resta uma economia tributária de $19 \%$.

29.2. A medida torna os juros considerados excessivos indedutíveis, segundo critérios e parâmetros legais. O objetivo é controlar o endividamento abusivo junto a pessoa vinculada no exterior, efetuado exclusivamente para fins fiscais

30. O art. 25 segue o mesmo princípio do art. 24, entretanto, é aplicado na hipótese de a pessoa jurídica domiciliada no Brasil contrair empréstimos com pessoa jurídica domiciliada em país ou dependência com tributação favorecida, ou que goze de regime fiscal privilegiado. Da mesma forma, esses empréstimos geram juros que reduzem, artificialmente, o resultado tributável no Brasil e, ao mesmo tempo, geram lucros que não serão tributados de maneira representativa no exterior. A medida restringe a dedutibilidade das despesas de juros de pessoas jurídicas residentes no Brasil quando pagos a entidades "off-shore", independentemente de vínculo societário. - fonte http://www.planalto.gov.br/ccivil_03/_ato2007-2010/2009/Exm/EMI-00180-MFMDIC-09-Mpv-472.htm
} 
A medida provisória $n^{\circ} 472 / 09$ foi convertida na Lei $n^{\circ} 12.249$, datada de 11 de junho de 2010 e regulamentada pela Instrução Normativa $n^{\circ} 1.154$, datada de 12 de maio de 2011.

Como o texto legal será a base dos comentários realizados nesse capítulo, faremos análise minuciosa de cada um dos dispositivos constantes nos três atos legais acima mencionados, utilizando-se também do texto da exposição de motivos que acompanhou a medida provisória originária, para, posteriormente, realizarmos as devidas críticas às regras estabelecidas no Brasil e sugestões de melhorias com base no direito comparado.

\subsection{Contexto legislativo}

Antes de iniciarmos a análise dos textos de direito positivo, entendemos relevante realizar breve introdução acerca do contexto legislativo que cercou referidas normas, desde a publicação da medida provisória $n^{\circ} 472 / 09$ até a regulamentação por meio da Instrução Normativa $\mathrm{n}^{\mathrm{o}} 1.154 / 11$.

Conforme já tivemos a oportunidade de registrar, o texto original da Medida Provisória $n^{\circ} 472 / 09$, em seus artigos 24 e 25, estabeleceu as regras de subcapitalização no Brasil de maneira imperfeita, criando barreiras praticamente intransponíveis para a sua aplicação em grande número de empresas, bem como apresentando diversas lacunas, que provavelmente não poderiam ser superadas ou elucidadas por meio de normativos infralegais, visto que eventual esclarecimento poderia extrapolar os ditames legais. ${ }^{191}$

Desta forma, após a publicação da referida medida provisória, diversas entidades de classe no setor da indústria, comércio e serviços, organizaram grupos de trabalho dedicados ao estudo das regras de subcapitalização, grupos estes que receberam o encargo de propor melhorias às regras recém implementadas, de maneira a torná-las exequíveis e condizentes a realidade e o contexto atual dos negócios desenvolvidos pelos diversos tipos de empresas existentes no país. ${ }^{192}$

${ }^{191}$ VICENTINI, Marcelo Fonseca. Thin Capitalization e seus Impactos para Bancos. In MOSQUERA, Roberto Quiroga (coord.). O direito tributário e o mercado financeiro e de capitais. São Paulo: Dialética, 2010, v.2, p. 246.

${ }^{192}$ VICENTINI, Marcelo Fonseca. Ob. Cit, p.246. 
O trabalho desenvolvido por diversas entidades de classe resultou na interferência direta da sociedade na produção de normas, por meio de reuniões com a Receita Federal, Deputado e Senador relatores da Medida Provisória n 472/09, situação esta refletida em melhorias significativas verificadas no texto final convertido em Lei, sob o $\mathrm{n}^{\mathrm{o}}$ 12.249/10, quando comparado ao texto original constante da então Medida Provisória no 472/09. ${ }^{193}$

Como consequência lógica do trabalho desenvolvido entre a publicação da Medida Provisória $n^{\circ} 472 / 09$ e da Lei $n^{\circ} 12.249 / 10$ e em evidente reconhecimento da necessidade de diálogo entre as autoridades fiscais e a sociedade, a Receita Federal solicitou às referidas entidades de classe a elaboração de minuta de Instrução Normativa, minuta esta que, com pequenos ajustes, culminou na publicação da Instrução Normativa $n^{\circ} 1.154 / 11 .{ }^{194}$

Realizados esses breves comentários iniciais, passamos à análise do texto de direito positivo onde buscaremos discorrer sobre os principiais conceitos existentes nos três atos legais.

5.2 Regras de subcapitalização adotadas no direito brasileiro

Adotaremos como base dos comentários o texto da Lei $\mathrm{n}^{\circ}$ 12.249/10 e apontaremos as situações onde o texto representa alteração com relação à Medida Provisória nº 472/09.

Adicionalmente, considerando que alguns dos artigos constantes da Instrução Normativa $\mathrm{n}^{\circ} 1.154 / 11$ não encontram fundamento legal, seja na Medida Provisória $\mathrm{n}^{\circ}$ 472/09, seja na Lei $n^{\circ} 12.249 / 10$, também faremos comentários específicos com relação a esses dispositivos.

\subsubsection{Conceito básico da norma}

Para melhor entendimento dos comentários e explicações relativos às regras de subcapitalização no direito brasileiro, necessário se faz a reprodução do texto legal, para posterior referência.

\footnotetext{
${ }^{193}$ VICENTINI, Marcelo Fonseca. Ob. Cit, p.246.
}

${ }^{194}$ VICENTINI, Marcelo Fonseca. Ob. Cit, p.246. 


\title{
$\mathrm{O}$ artigo 24 da Lei $\mathrm{n}^{\circ}$ 12.249/10 tratou das situações envolvendo pessoa vinculada,
}

\author{
residente ou domiciliada no exterior:
}

Art. 24. Sem prejuízo do disposto no art. 22 da Lei $\mathrm{n}^{\circ}$ 9.430, de 27 de dezembro de 1996, os juros pagos ou creditados por fonte situada no Brasil à pessoa física ou jurídica, vinculada nos termos do art. 23 da Lei $\mathrm{n}^{\circ}$ 9.430, de 27 de dezembro de 1996, residente ou domiciliada no exterior, não constituída em país ou dependência com tributação favorecida ou sob regime fiscal privilegiado, somente serão dedutíveis, para fins de determinação do lucro real e da base de cálculo da Contribuição Social sobre o Lucro Líquido, quando se verifique constituírem despesa necessária à atividade, conforme definido pelo art. 47 da Lei no 4.506, de 30 de novembro de 1964, no período de apuração, atendendo aos seguintes requisitos:

I - no caso de endividamento com pessoa jurídica vinculada no exterior que tenha participação societária na pessoa jurídica residente no Brasil, o valor do endividamento com a pessoa vinculada no exterior, verificado por ocasião da apropriação dos juros, não seja superior a 2 (duas) vezes o valor da participação da vinculada no patrimônio líquido da pessoa jurídica residente no Brasil;

II - no caso de endividamento com pessoa jurídica vinculada no exterior que não tenha participação societária na pessoa jurídica residente no Brasil, o valor do endividamento com a pessoa vinculada no exterior, verificado por ocasião da apropriação dos juros, não seja superior a 2 (duas) vezes o valor do patrimônio líquido da pessoa jurídica residente no Brasil;

III - em qualquer dos casos previstos nos incisos I e II, o valor do somatório dos endividamentos com pessoas vinculadas no exterior, verificado por ocasião da apropriação dos juros, não seja superior a 2 (duas) vezes o valor do somatório das participações de todas as vinculadas no patrimônio líquido da pessoa jurídica residente no Brasil.

$\S 1^{\circ}$ Para efeito do cálculo do total de endividamento a que se refere o caput deste artigo, serão consideradas todas as formas e prazos de financiamento, independentemente de registro do contrato no Banco Central do Brasil.

$\S 2^{\circ}$ Aplica-se o disposto neste artigo às operações de endividamento de pessoa jurídica residente ou domiciliada no Brasil em que o avalista, fiador, procurador ou qualquer interveniente for pessoa vinculada.

$\S 3^{\circ}$ Verificando-se excesso em relação aos limites fixados nos incisos I a III do caput deste artigo, o valor dos juros relativos ao excedente será considerado despesa não necessária à atividade da empresa, conforme definido pelo art. 47 da Lei $n^{\circ} 4.506$, de 30 de novembro de 1964, e não dedutível para fins do Imposto de Renda e da Contribuição Social sobre o Lucro Líquido.

$\S 4^{\circ}$ Os valores do endividamento e da participação da vinculada no patrimônio líquido, a que se refere este artigo, serão apurados pela média ponderada mensal.

$\S 5^{\circ} \mathrm{O}$ disposto no inciso III do caput deste artigo não se aplica no caso de endividamento exclusivamente com pessoas vinculadas no exterior que não tenham participação societária na pessoa jurídica residente no Brasil.

$\S 6^{\circ} \mathrm{Na}$ hipótese a que se refere o $\S 5^{\circ}$ deste artigo, o somatório dos valores de endividamento com todas as vinculadas sem participação no capital da entidade no Brasil, verificado por ocasião da apropriação dos juros, não poderá ser superior a 2 (duas) vezes o valor do patrimônio líquido da pessoa jurídica residente no Brasil.

$\S 7^{\circ} \mathrm{O}$ disposto neste artigo não se aplica às operações de captação feitas no exterior por instituições de que trata o $\S 1^{\circ}$ do art. 22 da Lei $n^{\circ} 8.212$, de 24 de julho de 1991, para recursos captados no exterior e utilizados em operações de repasse, nos termos definidos pela Secretaria da Receita Federal do Brasil. 
Por seu turno, o artigo 25 da Lei $\mathrm{n}^{\circ}$ 12.249/10 tratou das situações envolvendo os chamados popularmente de "paraísos fiscais":

\begin{abstract}
Art. 25. Sem prejuízo do disposto no art. 22 da Lei $\mathrm{n}^{\circ}$ 9.430, de 27 de dezembro de 1996, os juros pagos ou creditados por fonte situada no Brasil à pessoa física ou jurídica residente, domiciliada ou constituída no exterior, em país ou dependência com tributação favorecida ou sob regime fiscal privilegiado, nos termos dos arts. 24 e 24-A da Lei n ${ }^{\circ}$ 9.430, de 27 de dezembro de 1996, somente serão dedutíveis, para fins de determinação do lucro real e da base de cálculo da Contribuição Social sobre o Lucro Líquido, quando se verifique constituírem despesa necessária à atividade, conforme definido pelo art. 47 da Lei $\mathrm{n}^{\circ}$ 4.506, de 30 de novembro de 1964, no período de apuração, atendendo cumulativamente ao requisito de que o valor total do somatório dos endividamentos com todas as entidades situadas em país ou dependência com tributação favorecida ou sob regime fiscal privilegiado não seja superior a 30\% (trinta por cento) do valor do patrimônio líquido da pessoa jurídica residente no Brasil.

$\S 1^{\circ}$ Para efeito do cálculo do total do endividamento a que se refere o caput deste artigo, serão consideradas todas as formas e prazos de financiamento, independentemente de registro do contrato no Banco Central do Brasil.

$\S 2^{\circ}$ Aplica-se o disposto neste artigo às operações de endividamento de pessoa jurídica residente ou domiciliada no Brasil em que o avalista, fiador, procurador ou qualquer interveniente for residente ou constituído em país ou dependência com tributação favorecida ou sob regime fiscal privilegiado. $\S 3^{\circ}$ Verificando-se excesso em relação ao limite fixado no caput deste artigo, o valor dos juros relativos ao excedente será considerado despesa não necessária à atividade da empresa, conforme definido pelo art. 47 da Lei $\mathrm{n}^{\circ} 4.506$, de 30 de novembro de 1964, e não dedutível para fins do Imposto de Renda e da Contribuição Social sobre o Lucro Líquido.

$\S 4^{\circ}$ Os valores do endividamento e do patrimônio líquido a que se refere este artigo serão apurados pela média ponderada mensal.

$\S 5^{\circ} \mathrm{O}$ disposto neste artigo não se aplica às operações de captação feitas no exterior por instituições de que trata o $\S 1^{\circ}$ do art. 22 da Lei $\mathrm{n}^{\circ} 8.212$, de 24 de julho de 1991, para recursos captados no exterior e utilizados em operações de repasse, nos termos definidos pela Secretaria da Receita Federal do Brasil.
\end{abstract}

Como se pode depreender da leitura dos artigos 24 e 25 , os juros pagos ou creditados por fonte situada no Brasil à: i) pessoa física ou jurídica vinculada e residente ou domiciliada no exterior, bem como à ii) pessoa física ou jurídica residente, domiciliada ou constituída no exterior em país ou dependência com tributação favorecida ou sob regime fiscal privilegiado; somente serão dedutíveis se observados determinados limites e condições.

Caso não sejam observados os limites de endividamento e condições estabelecidos na norma e descritos detalhadamente a seguir, a despesa será considerada não necessária à atividade da empresa, conforme definido no art. 47 da Lei $\mathrm{n}^{\mathrm{o}}$ 4.506/64 e, consequentemente, não será dedutível na apuração do Imposto de Renda da Pessoa Jurídica e na base de cálculo da Contribuição Social. ${ }^{195}$

${ }^{195}$ VICENTINI, Marcelo Fonseca. Ob. Cit., p. 256. 
Da breve descrição acima, quatro elementos se sobressaem e merecem explicações específicas, antes de avançarmos para a análise das regras propriamente ditas: despesa necessária; juros; endividamento e credor residente no exterior.

\subsubsection{Despesa Necessária no âmbito das regras de subcapitalização}

Conforme já comentado nos itens 2.2 .3 e 4.1, o conceito de despesa necessária é, correntemente, determinado pelo art. 47 da Lei ${ }^{\circ}$ 4.506, de 1964 e está reproduzido no artigo 299 do Regulamento do Imposto de Renda, sendo consideradas necessárias as despesas usuais/normais pagas ou incorridas para a realização das transações ou operações exigidas pela atividade da empresa.

Tendo em vista que as expressões usual ou normal são bastante abrangentes, a receita federal buscou detalhar o seu entendimento por meio do Parecer Normativo - CST $n^{\circ} 32 / 81$ que traz elementos adicionais:

O gasto é necessário “quando essencial a qualquer transação ou operação exigida pela exploração das atividades, principais ou acessórias, que estejam vinculadas com as fontes produtoras dos rendimentos".

Por seu turno, ao tratar de despesa normal, o parecer normativo afirma que é "aquela que se verifica comumente no tipo de operação ou transação efetuada e que, na realização do negócio, se apresenta de forma usual, costumeira ou ordinária. O requisito de usualidade deve ser interpretado na acepção de habitual na espécie de negócio".

O autor Edmar Oliveira Andrade Filho, ao comentar a dedução de despesas necessárias observa que o requisito da normalidade pode ser analisado sob os aspectos qualitativo e quantitativo: sob o viés qualitativo, a despesa é normal quando mantém íntima e insuperável ligação com as atividades corriqueiras da empresa e, quanto ao elemento quantitativo, a despesa é considerada normal se os valores desembolsados forem razoáveis, ou seja, o valor pago deve corresponder a uma justa retribuição pelos bens e serviços obtidos segundo as regras de mercado. ${ }^{196}$

\footnotetext{
${ }^{196}$ ANDRADE FILHO, Edmar Oliveira. Imposto de renda das empresas. São Paulo: Atlas, 2004, p. 169.
} 
Além do citado parecer normativo, o próprio site da receita federal na internet traz atualmente diversas referências e explicações acerca do conceito de despesa necessária, com exemplos concretos do que pode ser considerado despesa necessária, e portanto dedutível na apuração do imposto de renda da pessoa jurídica e o que não pode ser considerado despesa necessária. ${ }^{197}$

Ainda que a receita federal tenha buscado elucidar o conceito, o tema despesa usual ou normal sempre foi objeto de divergência entre fisco e contribuinte, havendo uma infinidade de decisões dos tribunais administrativos e judiciais acerca do tema.

Podemos citar como exemplo, decisão do antigo Conselho de Contribuintes em 2005, acórdão 107-08.400 ${ }^{198}$, cujo voto do conselheiro Carlos Alberto Gonçalves Nunes foi bastante didático ao tentar conciliar os interesses do fisco e dos contribuintes:

(...) o fisco não pode intervir em questão de conveniência e oportunidade. Pode sim demonstrar que determinados custos ou despesas estão em desacordo com os ditames da lei fiscal.

Afinal, a empresa, como um ente econômico, tem o fito de lucro, o que é incompatível com a realização de despesas desnecessárias, sobretudo quando se reveste em sociedade anônima, em que os acionistas sempre estão atentos ao objetivo de lucro.

Há portanto, em princípio, uma presunção de que os gestores, salvo no caso de dolo, fraude ou simulação, não apropriem despesas inexistentes ou desnecessárias.

É certo que cabe ao contribuinte comprovar a necessidade de seus custos e despesas operacionais e encargos para que sejam dedutíveis, através da escrituração regular e documentos hábeis e idôneos, cabendo à autoridade administrativa a prova da inveracidade dos fatos assim registrados. (...)

Os comentários acima se mostram necessários, pois a regra contida no artigo 47 da Lei $n^{\circ} 4.506 / 64$ é central na apuração do imposto sobre a renda, visto que é aplicável a todas as despesas para as quais não haja uma norma específica sobre sua dedutibilidade, sendo que o voto do conselheiro Carlos Alberto Gonçalves Nunes parcialmente reproduzido acima se mostra como um bom parâmetro para definir os limites desta dedutibilidade.

\footnotetext{
${ }^{197}$ http://www.receita.fazenda.gov.br/pessoajuridica/dipj/2005/pergresp2005/pr335a347.htm

${ }^{198} \mathrm{http}: / /$ carf.fazenda.gov.br/sincon/public/pages/ConsultarJurisprudencia/listaJurisprudenciaCarf.jsf
} 
Por seu turno, conforme leciona Ricardo Mariz, para determinadas tipos ou espécies de despesas há normas especiais que, podem: (a) proibir a dedutibilidade de uma determinada despesa; (b) limitar o valor da sua dedutibilidade; (c) condicionar a sua dedutibilidade ao cumprimento de algum requisito, o qual pode ser uma determinada forma de comprovação; (d) determinar a dedução em período-base diferente no qual tenha sido contabilizada, ou ainda (e) atribuir-lhe algum tratamento fiscal específico (como certas deduções em dobro, a título de incentivo fiscal). ${ }^{199}$

Segundo a divisão feita por Ricardo Mariz, observamos que as regras de subcapitalização se enquadram no segundo grupo, ou seja, caracterizam normas especiais que limitaram o valor da dedutibilidade das despesas com juros, na medida em que os juros excedentes aos limites estabelecidos nos artigos 24 e 25 da Lei $n^{\circ} 12.249 / 10$ serão considerados indedutíveis para fins de determinação do lucro real e da base de cálculo da Contribuição Social sobre o lucro líquido - CSLL.

Em outras palavras, pode-se afirmar que com o estabelecimento das regras de subcapitalização no Brasil, os juros pagos ou creditados por fonte situada no Brasil à pessoa física ou jurídica vinculada e residente ou domiciliada no exterior, bem como à pessoa física ou jurídica residente, domiciliada ou constituída no exterior em país ou dependência com tributação favorecida ou sob regime fiscal privilegiado, somente serão considerados despesas necessárias e, portanto, dedutíveis na apuração do lucro real e da base de cálculo da CSLL, até os limites estabelecidos nos artigos 24 e 25 da Lei no 12.249/10 e descritos a seguir.

Por seu turno, os juros pagos ou creditados, ainda que se amoldem ao conceito trazido pelo artigo 47 da Lei 4.506/64, mas sejam excedentes aos limites estabelecidos nos artigos 24 e 25 da Lei $n^{\circ} 12.249 / 10$, não serão dedutíveis na apuração do lucro real e da base de cálculo da CSLL, pois serão considerados despesas não necessárias.

${ }^{199}$ OLIVEIRA, Ricardo Mariz de. Ob. Cit. p. 685 à 723. 
Apesar da Lei $n^{\circ}$ 12.249/10 e da Instrução Normativa $n^{\circ} 1.154 / 11$ citarem diversas vezes a palavra juros, não encontramos nos citados normativos nenhuma conceituação do termo.

Considerando a ausência de conceituação nos normativos, mostra-se relevante buscar o conceito adequado do termo juros, para que entender o alcance da lei.

Ezio Vanoni ensina que a finalidade do interprete não é nem a de pesquisar a vontade estática dos órgãos que tem criado a lei, nem a de extrair o direito da consciência jurídica popular, mas o de chegar a compreender todo o alcance da lei considerada como a vontade ativa do Estado. ${ }^{200}$

Prossegue o autor, ao trata da interpretação gramatical ou literal, afirmando que o interprete em seu primeiro contato com a norma escrita deve levar em conta o significado das palavras através das quais o pensamento legislativo se manifesta.

Nesse sentido, as palavras devem ser entendidas segundo o seu significado próprio e segundo a conexão que tenham entre si. Antes de tudo, deve-se levar em conta o sentido que as palavras têm na linguagem comum, porque dirigindo o legislador a todos os indivíduos, ao ditar a norma terá procurado escolher a fórmula que melhor possa ser compreendida por aquele aos quais se dirige. ${ }^{201}$

Acrescenta Ezio Vanoni: “deve-se ainda levar em conta a significação atribuída às palavras pelo uso cientifico. Nas leis tributárias encontram-se frequentemente termos definidos exatamente pela ciência financeira ou economia". ${ }^{202}$

Considerando as valiosas lições de Ezio Vanoni buscamos identificar a definição de juro na linguagem comum ou na ciência financeira e econômica e nesse sentido a obra de

\footnotetext{
${ }^{200}$ VANONI, Ezio. Natureza e interpretação das leis tributárias. Tradução de Rubens Gomes de Sousa. Rio de Janeiro: Edições Financeiras, 1932, p. 209.

${ }^{201}$ VANONI, Ezio. Ob. Cit., p. 210.

${ }^{202}$ VANONI, Ezio. Ob. Cit., p. 212.
} 
Luís Antonio Scavone Junior intitulada Juros no direito brasileiro nos auxilia, na medida em que esclarece:

Etimologicamente "juro", é uma adaptação do latim jure - de jus, juris- com significado de direito. Denota a linguagem portuguesa a singularidade de designar os interesses do dinheiro com a expressão 'juro’ que significa direito, como corruptela do latim jus, juris.

Aplicado no plural - juros - exprime os interesses, ganhos ou lucros que o detentor do capital aufere pela inversão, ou seja, pelo uso por alguém que não possui capital. Não se confunde com o prêmio, que representa a paga pelo risco assumido, como sói ocorrer com o contrato de seguro.

Acorde com a clássica e sempre acolhida lição de Washington de Barros Monteiro, "juros são o rendimento do capital, os frutos produzidos pelo dinheiro. Assim como o aluguel constitui o preço correspondente ao uso da coisa infungível no contrato de locação, representam os juros a renda de determinado capital. ${ }^{203}$

Por seu turno, observamos que o código civil nos auxilia no entendimento da expressão juros segundo o direito privado, pois traz os seus elementos essenciais: "os juros são a remuneração ou os frutos civis de um determinado capital do qual são acessórios (Código Civil de 1916, arts. 60 e 178; § 10, III; Código Civil de 2002, art. 92) e, bem assim, representam um acréscimo real ao valor inicial, espelhando rendimento calculado a partir de determinada taxa". ${ }^{204}$

Desta forma, pode-se afirmar que além da definição trazida por Luís Antônio Scavone, há um conceito de direito privado de juros, trazido pelo código civil e que, em nossa opinião, são consistentes, não havendo divergência entre a linguagem comum e o direito privado.

Nesse ponto, caberia analisar se o conceito de juros existente na linguagem comum e no direito privado deve ser utilizado para a interpretação da norma tributária ou não.

O artigo 109 do Código Tributário Nacional pode trazer alguma luz sobre a questão acima, na medida em que determina:

Art. 109. Os princípios gerais de direito privado utilizam-se para pesquisa da definição, do conteúdo e do alcance de seus institutos, conceitos e formas, mas não para definição dos respectivos efeitos tributários.

${ }^{203}$ SCAVONE Junior, Luiz Antonio. Ob. Cit., p. 41.

${ }^{204}$ SCAVONE Junior, Luiz Antonio. Ob. Cit., p. 41. 
Ao comentar o referido artigo, Luís Eduardo Schoueri afirma haver duas leituras possíveis: uma pela autonomia do Direito Tributário e outra que propõe o equilíbrio entre o Direito Tributário e o Direito Privado ${ }^{205}$, nos parecendo ser essa segunda, a leitura mais razoável.

Segundo essa leitura, o Direito Tributário não está submetido ao Direito Privado e o legislador é livre para criar seus próprios institutos, por outro lado, é razoável admitir que uma expressão já conhecida no ordenamento tenha o significa que lhe é comumente atribuído. Nesse caso, dir-se-á que, se o legislador tributário não manifestou sua decisão quanto a lhe conferir sentido diverso, toma-se o comum. ${ }^{206}$

Nesta linha, havendo em uma norma tributária, conceito de direito privado, a priori, o Direito Tributário faz uso desse conceito; nada impede, porém, que, para fins tributários, o conceito de direito privado seja alterado, desde que isso seja feito de modo expresso. ${ }^{207}$

Aliomar Baleeiro também se manifesta neste sentido ao afirmar que o legislador reconhece o império das normas de Direito Civil e Comercial quanto à definição, conteúdo e alcance dos institutos, conceitos e formas consagradas no campo desses dois ramos jurídicos; por outro lado, o artigo 109 autoriza o legislador tributário a atribuir a um instituto de direito privado - dentro dos limites constitucionais existentes - efeitos tributários peculiares, desde que o faça de maneira expressa e, caso não o fizer, não pode o interprete adaptar princípio ou instituto de Direito Privado para aplicar-lhe efeitos tributários especiais. ${ }^{208}$

Como a Lei $\mathrm{n}^{\mathrm{o}}$ 12.249/10 a Instrução Normativa $\mathrm{n}^{\circ}$ 1.154/11 citaram diversas vezes a palavra juros, mas não a conceituaram expressamente, entendemos que o termo deve ser interpretado, para fins de aplicação das regras de subcapitalização, de acordo com o conceito do direito privado.

\footnotetext{
${ }^{205}$ SCHOUERI, Luís Eduardo. Direito Tributário. São Paulo: Saraiva, 2011, p. 645.

${ }^{206}$ SCHOUERI, Luís Eduardo. Ob. Cit. (nota 205), p. 646.

${ }^{207}$ MACHADO, Antônio Cláudio da Costa e QUEIROZ, Mary Elbe (coords.). Código Tributário Nacional Interpretado. São Paulo: Manole, 2010, p. 149.

${ }^{208}$ BALEEIRO, Aliomar. Direito tributário brasileiro. $11^{\circ}$ ed. Atualizada por Misabel Abreu Machado Derci. Rio de Janeiro: Forense, 2001, p. 685.
} 
Considerando a constatação que não há conceituação expressa no direito tributário da palavra juros e a conclusão que ante este fato, devemos nos socorrer do direito privado, entendemos que o conceito deve ser obtido a partir do código civil: "os juros são a remuneração ou os frutos civis de um determinado capital do qual são acessórios e, bem assim, representam um acréscimo real ao valor inicial, espelhando rendimento calculado a partir de determinada taxa".

Essa conclusão mostra-se particularmente relevante para as regras de subcapitalização pois define os contornos do que deve ser considerado não dedutível para fins de thin capitalization e qualquer valor que seja reconhecido como despesa, mas que não se enquadre nesta definição, em princípio, não deveria ser atingido pelas limitações das regras em comento.

\subsubsection{Endividamento}

Diferentemente do que acontece com os juros, a Lei $\mathrm{n}^{\circ}$ 12.249/10 buscou delimitar o alcance da expressão endividamento, ao definir no parágrafo $§ 1^{\circ}$ do artigo 24 e 25 :

$\S 1^{\circ}$ Para efeito do cálculo do total de endividamento a que se refere o caput deste artigo, serão consideradas todas as formas e prazos de financiamento, independentemente de registro do contrato no Banco Central do Brasil.

Inicialmente cumpre-nos observar que a redação do parágrafo primeiro acima reproduzida deixa clara a intenção do legislador, qual seja, abarcar o maior número possível de operações, de maneira a se evitar a burla da lei em função da natureza jurídica empregada para o endividamento.

Cumpre inicialmente fazer referencia ao comentário de Nereida de Miranda Finamore Horta que afirma que a palavra financiamento não foi colocada na sua acepção técnica verdadeira, qual seja, entrega de recursos para aplicação num fim específico, mas sim num conceito de dívida, de operação de crédito, não devendo, portanto, ser interpretada na sua literalidade. ${ }^{209}$

\footnotetext{
${ }^{209}$ HORTA, Nereida de Miranda Finamore. As regras de Thin Captalization e a exclusão de operações de repasses realizadas pelas instituições financeiras. In MOSQUERA, Roberto Quiroga (coord.). O direito tributário e o mercado financeiro e de capitais. São Paulo: Dialética, 2010, v.2, p. 291.
} 
Tendo em vista a ausência de conceituação especifica de endividamento, seguimos linha de entendimento semelhante a que adotamos quando tratamos dos juros e relembramos os ensinamos de Ezio Vanoni que afirma que as palavras devem ser entendidas segundo o seu significado próprio e deve-se levar em conta o sentido que as palavras têm na linguagem comum. ${ }^{210}$

Desta forma, observamos que endividamento ${ }^{211}$ na linguagem comum é entendido como o montante de dívidas de determina pessoa física ou jurídica e por dívida ${ }^{212}$ entendese o que se deve ou a obrigação de pagar alguma quantia de dinheiro a outrem.

Considerando o conceito de endividamento da linguagem comum, bem como a redação do parágrafo $1^{\circ}$ anteriormente referido, pode-se inferir que o legislador definiu que qualquer forma e prazo de dívida contraída com pessoas vinculadas ou com paraísos fiscais deve respeitar os limites correspondentes de subcapitalização.

Entretanto, como se observa em diversas outras situações, o legislador, na ânsia de tentar evitar o descumprimento da regra, empregou um conceito popular, neste caso, de endividamento, ligando-o ao conceito de financiamento, porém não foi suficientemente claro a ponto de esclarecer o efetivo alcance do dispositivo, não sendo explícito, por exemplo, se instrumentos de captação de recursos mais modernos, como os instrumentos híbridos, estão incluídos ou não no conceito de endividamento e, consequentemente, se devem observar limites de subcapitalização ou não.

Esclarece Rafael Minervino Bispo que os meios mais comuns de injeção de recursos em uma sociedade são por intermédio de ativos (capital ou equity) ou passivos (empréstimos - debt). Não obstante, cada vez mais são realizadas operações financeiras complexas, sendo que alguns instrumentos financeiros misturam elementos das duas categorias, resultando nos instrumentos conhecidos como híbridos, por combinarem investimentos por dívida com algumas feições de capital ou vice-versa. ${ }^{213}$

\footnotetext{
${ }^{210210}$ VANONI, Ezio. Ob. Cit., p. 210.

${ }^{211}$ http://michaelis.uol.com.br/moderno/portugues/index.php?lingua=portuguesportugues\&palavra=endividamento

${ }_{212} \mathrm{http} / / /$ michaelis.uol.com.br/moderno/portugues/index.php?lingua=portugues-portugues\&palavra=dívida

${ }^{213}$ BISPO, Rafael Minervino. Ob. Cit., p. 59.
} 
Na mesma linha, afirma Francisco Alfredo Garcia Prats que tradicionalmente considerava-se que divida e patrimônio tinham tendências separadas e bem definidas; entretanto, a distinção é cada vez mais superada pelo uso e pela profusão de instrumentos financeiros híbridos que podem adaptar-se às necessidades e posição de investidores e requerentes de capital. ${ }^{214}$

Considerando a capacidade de usar os instrumentos financeiros híbridos e adaptálos às demandas e necessidades específicas de cada circunstância em particular, existe uma grande variedade e tipos de instrumentos financeiros híbridos, tais como ações resgatáveis, títulos conversíveis, debentures de participação, dívida subordinada, dentre outros. ${ }^{215}$

Sem dúvida, a situação acima descrita trás um grande desafio para o legislador, na medida em que não basta listar eventuais instrumentos que possam estar sujeitos às regras de subcapitalização, visto que a cada dia surgem novos instrumentos.

Por outro lado, a ausência de definição clara acerca do alcance da expressão endividamento pode significar que uma série de instrumentos hoje largamente utilizados, não sejam contemplados pela norma, por não se enquadrarem no conceito de endividamento da linguagem comum.

\subsubsection{Credor residente no exterior}

Em que pese ser possível inferir da leitura dos artigos 24 e 25 da Lei 12.249/10 (reproduzidos no item 5.2.1) que as regras de subcapitalização aplicam-se apenas às situações em que o credor é residente no exterior, após a publicação da referida lei, surgiram debates acerca da sua aplicação para situações em que o credor é residente no país como, por exemplo, quando determinada instituição financeira sediada no país concede empréstimo à pessoa não vinculada também sediada no país, tendo como avalista, fiador ou interveniente pessoa física ou jurídica vinculada residente no exterior ou residente em país com tributação favorecida.

\footnotetext{
${ }^{214}$ PRATS, Francisco Alfredo Garcia. “Qualificação dos Instrumentos Financeiros Híbridos em Tratados Fiscais” - Tradução de Célia Korn. In Direito Tributário Atual, vol. 26. São Paulo: Dialética, 2011, p. 79. ${ }^{215}$ PRATS, Francisco Alfredo Garcia. Ob. Cit., p. 79.
} 
Buscando esclarecer referida dúvida, a Receita Federal, ao regulamentar o tema, incluiu artigo na Instrução Normativa ${ }^{\circ} 1.154 / 11$ que assim dispôs:

Art. 10. Os limites previstos nos arts. $2^{\circ}$ e $5^{\circ}$ não se aplicam às operações de endividamento com credor residente ou domiciliado no Brasil, ainda que a operação tenha como avalista, fiador, procurador ou qualquer interveniente:

I - pessoa física ou jurídica vinculada, residente ou domiciliada no exterior;

II - pessoa física ou jurídica residente, domiciliada ou constituída no exterior, em país ou dependência com tributação favorecida ou sob regime fiscal privilegiado.

$\S 1^{\circ}$ No caso de inadimplemento de operação de crédito de que trata o caput, em que o avalista, o fiador, o procurador ou qualquer interveniente na operação for alguma das pessoas mencionadas nos incisos I e II do caput, aplicam-se os limites previstos nos arts. $2^{\circ}$ ou $5^{\circ}$, conforme o caso, em relação aos juros apropriados a partir da data em que a pessoa no exterior efetuar o pagamento da dívida no Brasil.

$\S 2^{\circ} \mathrm{O}$ disposto neste artigo não se aplica na hipótese em que a empresa credora residente no Brasil seja mera intermediária entre a pessoa jurídica avalista, fiadora ou procuradora no exterior e a tomadora dos recursos no Brasil.

Como se observa na redação acima reproduzida, o artigo 10 não deixa dúvidas que as disposições dos artigos 24 e 25 ( $2^{\circ}$ e $5^{\circ}$ na Instrução Normativa, respectivamente) não se aplicam para operações de endividamento com credor residente ou domiciliado no Brasil.

Alberto Xavier atribui à residência do credor a nomenclatura de estraineidade e esclarece "do requisito da estraineidade resulta desde logo que o regime de subcapitalização não se aplica às situações puramente internas, mesmo as estabelecidas entre um devedor residente no Brasil e um estabelecimento permanente (filial, agência, representante) de credor domiciliado no exterior". ${ }^{216}$

Por seu turno, a instrução normativa também esclarece que, caso referidas operações tenham como avalista, fiador, procurador ou qualquer interveniente pessoa física ou jurídica vinculada residente no exterior ou residente em país com tributação favorecida ou sob regime fiscal privilegiado e haja inadimplemento da operação original (estabelecida entre credor e devedores residentes e domiciliados no país), aplicar-se-ão os limites das regras de subcapitalização a partir da data em que a pessoa residente ou domiciliada no exterior efetuar o pagamento da dívida no Brasil.

Interessante observar ainda que a instrução normativa acrescentou no parágrafo $2^{\circ}$ do artigo 10 dispositivo que não existia na Lei 12.249/10, extrapolando assim os ditames

${ }^{216}$ XAVIER, Alberto. Obra Cit., p. 348. 
legais e criando hipótese de aplicação das regras de subcapitalização passível de questionamento no judiciário na medida em que tentar ampliar indevidamente o escopo da norma.

5.2.2 Artigo 24 - Juros pagos ou creditados por fonte situada no Brasil à pessoa física ou jurídica, vinculada

Como se pode observar do texto reproduzido no item 5.2.1, o legislador brasileiro optou por criar duas regras distintas para determinar o limite de dedutibilidade dos juros pagos, uma para os juros pagos às pessoas vinculadas e residentes ou domiciliadas no exterior e outra para pessoas residentes, domiciliadas ou constituídas em país ou dependência com tributação favorecida ou sob regime fiscal privilegiado (ainda que não vinculadas). ${ }^{217}$

Nesse sentido, cumpre-nos avaliar o conceito de pessoa vinculada adotado, bem como o conceito de país ou dependência com tributação favorecida ou sob regime fiscal privilegiado e, ainda, os limites aplicáveis as essas regras.

\subsubsection{Conceito de pessoa vinculada}

O conceito de pessoa vinculada não é novo no direito pátrio e as regras que tratavam da distribuição disfarçada de lucros já previam a sua aplicação às pessoas vinculadas segundo um conceito bastante abrangente, incluindo não apenas o titular, sócio ou acionista da pessoa jurídica, mas também outras figuras que nem sequer participavam do capital da empresa. ${ }^{218}$

Posteriormente, as regras de preço de transferência também adotaram conceito de pessoa vinculada bastante abrangente, sendo este o conceito adotado no âmbito das regras de subcapitalização, conforme se observa no caput do artigo 24 da lei 12.249/10, que faz remissão ao artigo 23 da Lei $n^{\circ}$ 9.430/96.

\footnotetext{
${ }^{217}$ VICENTINI, Marcelo Fonseca. Ob. Cit., p. 256.

${ }^{218}$ SCHOUERI, Luís Eduardo. Ob. Cit. (nota 182), p. 80.
} 
Referido artigo 23 que traz o conceito de pessoa vinculada adotado pelas regras de preços de transferência e posteriormente pelas regras de subcapitalização é bastante abrangente e não se limita a uma relação direta entre a empresa brasileira e a sua matriz no exterior, incluindo participações indiretas, associações em forma de consórcio ou condomínio, e até mesmo situações onde a pessoa física residente no exterior for parente ou afim até o terceiro grau, cônjuge ou companheiro de qualquer de seus diretores ou de seu sócio ou acionista controlador em participação direta ou indireta.

Neste sentido, as críticas formuladas quando da edição das regras de preço de transferência se mostram plenamente aplicáveis às regras de subcapitalização.

Ao tratar do preço de transferência, observa Paulo Ayres Barreto que dentre as hipóteses de vinculação entre pessoas físicas e jurídicas residentes ou domiciliadas no exterior com a pessoa jurídica domiciliada no Brasil, algumas são evidentes como, por exemplo, as que se estabelecem vínculo entre a matriz ou a filial de empresa brasileira. Por outro lado, em outras hipóteses, conquanto efetivamente algum vínculo exista, não é de se imaginar seja tal vínculo suficiente para se presumir a manipulação de preços, como é o caso de mera coligação, consórcio, condomínio, ou decorrente de contrato de agenciamento, distribuição ou concessão. ${ }^{219}$

O autor Alberto Xavier também tece críticas à abrangência do artigo e afirma que o círculo das pessoas vinculadas extravasa em muito o âmbito a que se aplicam os tratados contra a dupla tributação, seguindo o modelo da OCDE; e, pela lógica do próprio regime, deveria restringir-se a reais relações de influência dominante, suscetíveis de afetar a objetividade dos negócios, que não se verificam necessariamente nos casos de simples coligação de empresas, de participação conjunta em sociedades coligadas, de consórcios ou de condomínios temporários. ${ }^{220}$

Entendemos que as ponderações dos professores Paulo Ayres Barreto e Alberto Xavier são plenamente aplicáveis as regras de subcapitalização, na medida em que nos parece um exagero do legislador pressupor que o endividamento de empresa brasileira com pessoas físicas ou jurídicas residentes no exterior com simples participação em sociedade

${ }^{219}$ BARRETO, Paulo Ayres. Ob. Cit., p. 122.

${ }^{220}$ XAVIER. Alberto. Ob. Cit., p. 299. 
coligadas ou condomínios temporários, pode influenciar na taxa de juros prática nesses negócios ou ainda que estas pessoas físicas ou jurídicas teriam condições/interesse de capitalizar a empresa brasileira por meio de aporte de capital (equity).

\subsubsection{Limites de endividamento com pessoa jurídica vinculada no exterior}

A regra brasileira de subcapitalização optou por diferenciar o endividamento com pessoa vinculada no exterior que tenha participação societária na pessoa jurídica residente no Brasil e o endividamento com vinculada no exterior que não tenha participação societária direta.

Relativamente ao endividamento com pessoa vinculada no exterior que tenha participação societária na pessoa jurídica residente no Brasil, o legislador estabeleceu que o limite de endividamento será 2 vezes o valor da participação da vinculada no patrimônio líquido da pessoa jurídica residente no Brasil.

Em números: caso determinada entidade no exterior (A), detenha $75 \%$ do capital social da empresa brasileira (B), cujo patrimônio líquido é 100, o limite de endividamento da empresa brasileira para com a sua vinculada no exterior (com participação direta) será de 150.

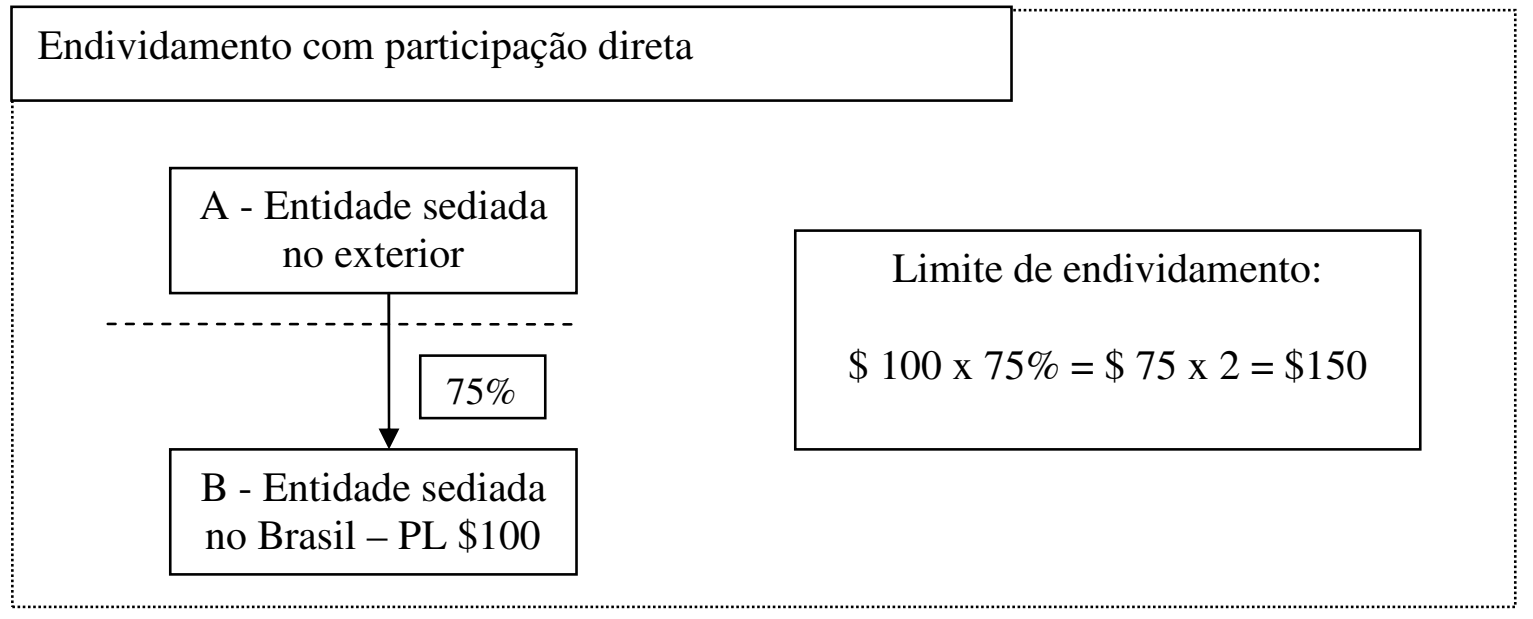

Diversamente do caso em que a vinculada no exterior detém participação direta no capital social da empresa brasileira, onde o limite é proporcional à participação, no caso do endividamento com pessoa vinculada no exterior que não tenha participação societária 
direta na empresa brasileira, o legislador estabeleceu que o limite de endividamento será 2 vezes o valor do patrimônio líquido da pessoa jurídica residente no Brasil.

Em números: caso o patrimônio líquido da empresa brasileira (C) é 100, o limite de endividamento da empresa brasileira para com a sua vinculada no exterior (A -com participação indireta, via B) será de 200.

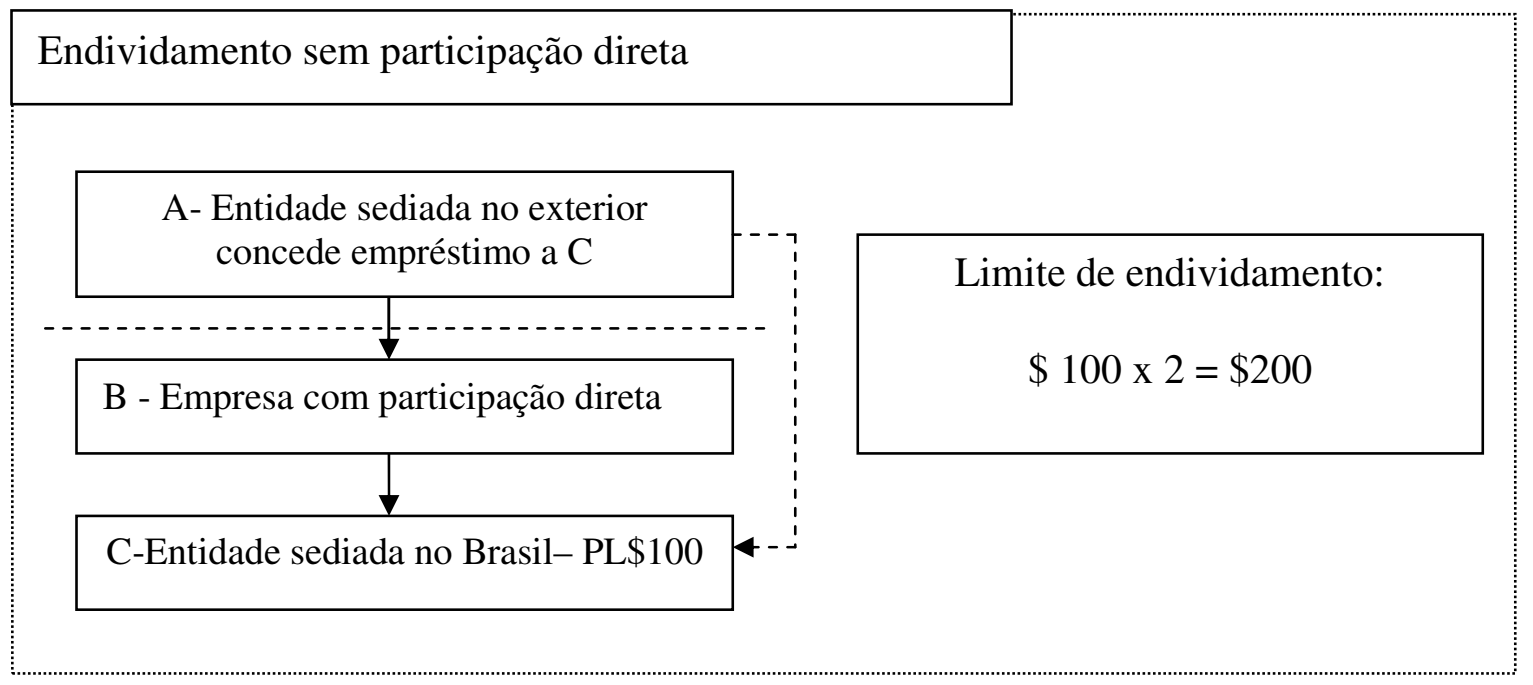

Observamos que a forma que regra foi estabelecida, diferenciando os casos onde há participação direta na empresa tomadora do empréstimo dos casos onde não há, pode dar ensejo ao planejamento dos grupos econômicos no sentido de conceder os empréstimos exclusivamente por empresas sediadas no exterior que não tenham participação societária direta, visto que este limite sempre será maior que o aplicável às empresas com participação direta (exceção feita aos casos onde a participação seja de $100 \%$, quando o limite da empresa com e sem participação será idêntico).

\subsubsection{Cumulação de limites de endividamento}

Complementa ainda a regra prevista no artigo 24 da Lei $\mathrm{n}^{\circ} 12.249$ que o somatório dos endividamentos com pessoas vinculadas no exterior não poderá ser superior a 2 vezes o valor do somatório das participações de todas as vinculadas no patrimônio líquido da pessoa jurídica residente no Brasil. 
Neste caso, caso haja empréstimos concedidos por empresas sediadas no exterior com e sem participação direta, o limite para endividamento será de 2 vezes o valor da participação das vinculadas no patrimônio líquido da pessoa jurídica residente no Brasil.

Novamente aqui vislumbramos a possibilidade de planejamento no sentido de não se conceder o empréstimo simultâneo por empresas com e sem participação, pois haverá limitação desnecessária para os empréstimos concedidos por empresas sem participação direta.

5.2.3 Artigo 25 - Credor residente em país ou dependência com tributação favorecida ou sob regime fiscal privilegiado

A regra brasileira optou ainda por diferenciar os limites aplicáveis às empresas brasileiras que tomam empréstimos de pessoa física ou empresa sediada em país ou dependência com tributação favorecida ou sob regime fiscal privilegiado (prevista no artigo 25 da Lei $n^{\circ}$ 12.249) dos empréstimos obtidos com pessoa física ou empresa vinculada no exterior (prevista no artigo 24 da Lei $n^{\circ} 12.249$ ), cujos limites e condições foram esclarecidos no item 5.2.2.

Nota-se que o disposto no artigo 25 da Lei $n^{\circ} 12.249$ leva em consideração apenas o local de residência, não sendo necessário haver vinculo entre o credor residente no exterior e o devedor brasileiro.

Desta forma, para melhor entendimento do disposto no artigo 25 da Lei ${ }^{\circ}$ 12.249, cumpre-nos, inicialmente, conceituar país ou dependência com tributação favorecida, bem como país ou dependência sob regime fiscal privilegiado.

5.2.3.1 Conceito de país ou dependência com tributação favorecida e regime físcal privilegiado

$\mathrm{O}$ artigo 25 da Lei $\mathrm{n}^{\circ} 12.249$ não trouxe conceito próprio de país ou dependência com tributação favorecida ou regime fiscal privilegiado e adotou técnica semelhante à 
adotada para pessoa vinculada, fazendo referência aos artigos 24 e $24-\mathrm{A}$ da Lei $\mathrm{n}^{\mathrm{o}}$ 9.430/96.

Desta forma, o conceito adotado pela Lei no 12.249 para país ou dependência com tributação favorecida é o seguinte:

Art. 24. As disposições relativas a preços, custos e taxas de juros, constantes dos arts. 18 a 22, aplicam-se, também, às operações efetuadas por pessoa física ou jurídica residente ou domiciliada no Brasil, com qualquer pessoa física ou jurídica, ainda que não vinculada, residente ou domiciliada em país que não tribute a renda ou que a tribute a alíquota máxima inferior a vinte por cento.

(...)

§ 4o Considera-se também país ou dependência com tributação favorecida aquele cuja legislação não permita o acesso a informações relativas à composição societária de pessoas jurídicas, à sua titularidade ou à identificação do beneficiário efetivo de rendimentos atribuídos a não residentes.

Por seu turno, o conceito de regime fiscal privilegiado, está definido no artigo 24-A da Lei 9.430/96 (inserido pela Lei $\mathrm{n}^{\circ}$ 11.727/08), que assim dispôs:

Art. 24-A. Aplicam-se às operações realizadas em regime fiscal privilegiado as disposições relativas a preços, custos e taxas de juros constantes dos arts. 18 a 22 desta Lei, nas transações entre pessoas físicas ou jurídicas residentes e domiciliadas no País com qualquer pessoa física ou jurídica, ainda que não vinculada, residente ou domiciliada no exterior.

Parágrafo único. Para os efeitos deste artigo, considera-se regime fiscal privilegiado aquele que apresentar uma ou mais das seguintes características:

I - não tribute a renda ou a tribute à alíquota máxima inferior a 20\% (vinte por cento);

II - conceda vantagem de natureza fiscal à pessoa física ou jurídica não residente:

a) sem exigência de realização de atividade econômica substantiva no país ou dependência;

b) condicionada ao não exercício de atividade econômica substantiva no país ou dependência;

III - não tribute, ou o faça em alíquota máxima inferior a $20 \%$ (vinte por cento), os rendimentos auferidos fora de seu território;

IV - não permita o acesso a informações relativas à composição societária, titularidade de bens ou direitos ou às operações econômicas realizadas.

Considerando a abrangência dos dispositivos legais, que poderiam impor ônus enorme ao contribuinte brasileiro, lhe obrigando a conhecer a legislação tributária de todos os países do mundo para determinar se determina país enquadra-se ou não nos conceitos 
acima, bem como evitando a arbitrariedade do aplicador do direito, as autoridades fiscais optaram por regular o tema por meio de uma instrução normativa.

Neste sentido, a Instrução Normativa de $n^{\circ}$ 1.037/10 atualmente veicula a lista dos países ou dependências, que, no entendimento das autoridades fiscais, refletem o disposto no artigo 24 e seu $\S 4^{\circ}$ e parágrafo único do artigo 24-A, ambos da Lei $n^{\circ} 9.430 / 96 .{ }^{221}$

Como conclusão do acima exposto, pode-se afirmar que qualquer endividamento de empresa brasileira com pessoa física ou jurídica domiciliada ou residente em qualquer um dos países constante da lista apresentada pela Instrução Normativa $\mathrm{n}^{\circ} 1.037 / 10$, deverá observar os limites de endividamento constante do artigo 25 da Lei 12.249.

Interessante notar que no tocante ao artigo 25, as regras de subcapitalização incidem independentemente da existência de vinculação entre uma pessoa jurídica brasileira e pessoa física ou jurídica residente no exterior. Por conseguinte, basta que os juros sejam pagos a beneficiário situado em pais ou dependência considerado como de tributação favorecida para que incidam as limitações impostas pela lei. ${ }^{22}$

5.2.3.2 Limites de endividamento com credor residente em país ou dependência favorecida ou sob regime fiscal privilegiado

Relativamente ao endividamento com pessoa física ou jurídica, residente, domiciliada ou constituída no exterior, em país ou dependência com tributação favorecida ou sob regime fiscal privilegiado, nos termos definidos no item 5.2.3.1 e 5.2.3.2 acima, o legislador estabeleceu que o limite de endividamento será 0,3 vezes (ou 30\%) o valor do patrimônio líquido da pessoa jurídica residente no Brasil, independentemente de haver vínculo entre estes ou não.

Em números: caso determinada entidade sediada nas referidas localidades (A), conceda empréstimos à empresa brasileira (B), cujo patrimônio líquido é 100, o limite de endividamento da empresa brasileira para com esta entidade será de 30.

\footnotetext{
${ }^{221}$ XAVIER. Alberto. Ob. Cit., p. 350.

${ }^{222}$ BISPO, Rafael Minervino. Ob. Cit., p. 117.
} 
Endividamento com país com tributação favorecida ou sob regime fiscal privilegiado

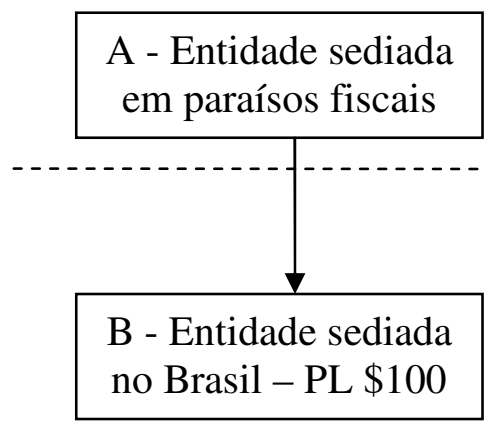

Limite de endividamento:

$\$ 100 \times 0,3=\$ 30$

\subsubsection{Avalista, fiador, procurador ou qualquer interveniente}

Em geral, o crédito concedido por um banco residente ou domiciliado fora do Brasil para uma empresa brasileira pertencente a um grupo multinacional, conta com uma garantia de uma vinculada também situada no exterior, de maneira que o empréstimo seja viabilizado ou que a taxa de juros cobrada na operação seja menor, tendo em vista a garantia concedida.

Observando essa prática, o legislador brasileiro buscou alcançar também as operações de endividamento de empresas brasileiras com pessoas não vinculadas no exterior, garantidas por uma vinculada à empresa brasileira (nos casos do artigo 24), bem como situações onde o empréstimo é garantido por um residente em país com tributação favorecida ou sob regime fiscal privilegiado (nos casos do artigo 25).

Entretanto, a Lei $\mathrm{n}^{\mathrm{o}} 12.249$ determinou que a regra de subcapitalização prevista no artigo 24 se aplica às operações de endividamento de pessoa jurídica residente ou domiciliada no Brasil em que o avalista, fiador, procurador ou qualquer interveniente for pessoa vinculada, ampliando em demasiado o rol de pessoas / situações que justificariam o dispositivo proposto, como por exemplo, determinado que a regra se aplicará quando qualquer interveniente for pessoa vinculada, ainda que este não seja responsável pelo pagamento da dívida.

Observam Luciana Rosanova Galhardo e Jorge Ney de Figueiredo Lopes Junior que a preocupação das autoridades reside na possível estruturação de operações de 
empréstimo entre partes relacionadas, onde um banco estrangeiro seja interposto com o mero fim de aparentar uma operação entre partes não relacionadas e, desta forma, a operação com o banco seria desconsiderada para que subsistisse apenas a garantia concedida pela empresa estrangeira. ${ }^{223}$

Por seu turno, parece um exagero a conclusão de que toda e qualquer operação de empréstimo concedido por uma empresa não relacionada à empresa brasileira possa ser tratada como sujeita às regras de subcapitalização com base no exclusivo fato de que seja garantida por uma empresa relacionada estrangeira, sem que se analisem os demais elementos e fatores da operação, na medida em que existem diversas formas de garantia. ${ }^{24}$

Essa também é a opinião de Alberto Xavier que afirma que ultrapassa os limites da proporcionalidade e da razoabilidade aplicar cega e mecanicamente essa presunção, que chega até a ser absurda quando nelas abrange um mero "procurador" ou "qualquer interveniente". 225

Considerando que o dispositivo legal ampliou em demasiado o rol de pessoas / situações que justificariam o estabelecimento da referida regra, a Receita Federal buscou restringir a abrangência do parágrafo $2^{\circ}$ do artigo 24 e 25 por meio da regulamentação e determinou no parágrafo $3^{\circ}$ do artigo $2^{\circ}$ da Instrução Normativa $n^{\circ} 1.154 / 11$ :

\begin{abstract}
Art. $2(\ldots)$
$\S 2^{\circ}$ Aplica-se o disposto neste artigo às operações de endividamento de pessoa jurídica residente ou domiciliada no Brasil com pessoa residente ou domiciliada no exterior em que o avalista, fiador, procurador ou qualquer interveniente na operação de endividamento for pessoa vinculada, sem prejuízo do disposto no art. 10.

$\S 3^{\circ} \mathrm{O}$ disposto no $\S 2^{\circ}$ aplica-se aos casos em que o interveniente, pessoa vinculada, seja responsável pelo pagamento total ou parcial da dívida, ainda que subsidiariamente.
\end{abstract}

A instrução normativa seguiu a direção correta, entretanto, entendemos que deveria ter determinado a aplicação da regra quando a pessoa vinculada fosse responsável pelo

223 GALHARDO, Luciana Rosanova e LOPES Junior, Jorge Ney de Figueiredo. As regras de subcapitalização e a atuação de bancos nacionais e estrangeiros na estruturação de operações de financiamento externo de empresas nacionais. In MOSQUERA, Roberto Quiroga (coord.). O direito tributário e o mercado financeiro e de capitais. São Paulo: Dialética, 2010, v.2, p. 217.

224 GALHARDO, Luciana Rosanova e LOPES Junior, Jorge Ney de Figueiredo. Ob. Cit., p. 218.

${ }^{225}$ XAVIER, Alberto. Ob. Cit., p. 352. 
pagamento total ou parcial da dívida em todas as situações, e não apenas no caso dos intervenientes.

Além de restringir a aplicação da regra nos casos dos intervenientes, o artigo 10 da Instrução Normativa $\mathrm{n}^{\circ} 1.154 / 11$ buscou esclarecer que os limites previstos nos artigos $2^{\circ} \mathrm{e}$ $5^{\text {o }}$ da Instrução Normativa (correspondentes aos artigos 24 e 25 da Lei 12.249) não se aplicam as operações de endividamento com credor residente ou domiciliado no Brasil, ainda que a operação tenha como avalista, fiador, procurador ou qualquer interveniente pessoa física ou jurídica vinculada, residente ou domiciliada no exterior ou pessoa física ou jurídica domiciliada ou constituída no exterior, em país ou dependência com tributação favorecida ou sob regime fiscal privilegiado.

Complementa ainda o parágrafo $1^{\circ}$ do referido artigo que no caso de inadimplemento da operação de crédito, os limites serão aplicáveis em relação aos juros apropriados a partir da data em que no exterior efetuar ao pagamento da dívida no Brasil:

Art. 10. Os limites previstos nos arts. $2^{\circ}$ e $5^{\circ}$ não se aplicam às operações de endividamento com credor residente ou domiciliado no Brasil, ainda que a operação tenha como avalista, fiador, procurador ou qualquer interveniente:

I - pessoa física ou jurídica vinculada, residente ou domiciliada no exterior;

II - pessoa física ou jurídica residente, domiciliada ou constituída no exterior, em país ou dependência com tributação favorecida ou sob regime fiscal privilegiado.

$\S 1^{\circ}$ No caso de inadimplemento de operação de crédito de que trata o caput, em que o avalista, o fiador, o procurador ou qualquer interveniente na operação for alguma das pessoas mencionadas nos incisos I e II do caput, aplicam-se os limites previstos nos arts. $2^{\circ}$ ou $5^{\circ}$, conforme o caso, em relação aos juros apropriados a partir da data em que a pessoa no exterior efetuar o pagamento da dívida no Brasil.

Interessante observar que o parágrafo $2^{\circ}$ do artigo 10 esclarece que o disposto no parágrafo $1^{\mathrm{o}}$ não se aplica na hipótese em que a empresa credora residente no Brasil seja mera intermediária:

$\S 2^{\circ} \mathrm{O}$ disposto neste artigo não se aplica na hipótese em que a empresa credora residente no Brasil seja mera intermediária entre a pessoa jurídica avalista, fiadora ou procuradora no exterior e a tomadora dos recursos no Brasil. 
O parágrafo $2^{\circ}$ do artigo 10 da Instrução Normativa $\mathrm{n}^{\circ} 1.154$ buscou evitar operação que se tornou bastante usual logo após a publicação da Medida Provisória $\mathrm{n}^{\circ}$ 472/09 (a instrução normativa foi publicada quase 1 ano e meio depois da Medida Provisória $\mathrm{n}^{\mathrm{o}} 472$ ) onde algumas empresas se utilizaram do artifício de tomar empréstimos de uma entidade não vinculada, mas com garantia de uma vinculada no exterior, buscando assim, evitar a aplicação das regras de subcapitalização.

Em que pese o dispositivo se fundar em situações concretas e buscar ampliar a aplicação das regras de subcapitalização, verificamos que este não encontra fundamento na Lei 12.249/10, o que pode ensejar questionamentos quanto a sua legalidade, visto que estabelece, por meio de instrução normativa, nova hipótese de aplicação das regras de subcapitalização.

\subsubsection{Operações de repasse realizadas por instituições financeiras}

Diferentemente de outros países que optaram por diferenciar as regras de subcapitalização aplicáveis para instituições financeiras e não financeiras, as regras brasileiras não realizaram referida diferenciação, estabelecendo o mesmo limite para os dois tipos de entidades.

Entretanto, ao não realizar a diferenciação entre as instituições financeiras e não financeiras, as regras estabelecidas na Medida Provisória $n^{\circ}$ 472/09 ignoraram o fato das instituições financeiras terem como atividade principal a intermediação financeira, assim entendida a tomada de recursos de diversas fontes, incluindo entidades vinculadas, e o repasse destes recursos para terceiros.

Em outras palavras, ao tomar empréstimos e repassar aos seus clientes, a instituição financeira está praticando operações intrínsecas ao seu objeto social e está amparada pela regulamentação expressa do Banco Central do Brasil, sendo gravemente penalizadas pelas regras estabelecidas pela Medida Provisória n ${ }^{\circ} 472 / 09 .{ }^{226}$

${ }^{226}$ GALHARDO, Luciana Rosanova e LOPES Junior, Jorge Ney de Figueiredo. Ob. Cit., p. 220. 
Além do claro prejuízo às instituições financeiras, a aplicação da mesma regra a todas às pessoas jurídicas indistintamente poderia comprometer de maneira relevante a oferta de crédito no país, visto que a captação no exterior é uma fonte importante de recursos para as instituições financeiras, valores estes que, posteriormente, são repassados localmente. ${ }^{227}$

Constatada essa situação, as instituições financeiras apresentaram pleito ao governo no sentido de excluir as operações de repasse das regras de subcapitalização no que foram atendidas, com a inclusão do parágrafo $7^{\circ}$ no artigo 24 e $5^{\circ}$ no artigo 25 da Lei 12.249/10, sendo que a Lei delegou à Secretaria da Receita Federal do Brasil a regulamentação do dispositivo, o que ocorreu por meio do artigo $6^{\circ}$ da Instrução Normativa $n^{\circ} 1.154 / 11$ :

Art. $6^{\circ}$ Os limites previstos nos arts. $2^{\circ}$ e $5^{\circ}$ não se aplicam às operações de captação feitas no exterior por bancos comerciais, bancos de investimentos, bancos de desenvolvimento, caixas econômicas, sociedades de crédito, financiamento e investimento, sociedades de crédito imobiliário, empresas de arrendamento mercantil e cooperativas de crédito para recursos captados no exterior e utilizados em operações de repasse.

Parágrafo único. Entende-se por operação de repasse a concessão de crédito vinculada à captação externa que lhe serve de lastro, na qual a instituição repassadora transfere à repassatária, pessoa física ou jurídica no País, o risco de variação cambial da captação externa, quando em moeda estrangeira, na mesma indexação da captação externa, não sendo cobrado, pelos serviços de intermediação financeira, qualquer outro ônus, além da comissão de repasse.

A regulamentação da Receita Federal deu efetividade ao dispositivo legal e refletiu o pleito das instituições financeiras de maneira que a os recursos captados no exterior com a finalidade de fomentar operações de crédito no país foram excepcionados da regra, sendo certo que valores captados no exterior por instituições financeiras, mas não utilizados para repasse a terceiros devem observar os limites estabelecidos pela Lei $\mathrm{n}^{\circ}$ 12.249.

${ }^{227}$ VICENTINI, Marcelo Fonseca. Ob. Cit, p.259. 
5.3 Normas de subcapitalização e os tratados para evitar a dupla tributação assinados pelo Brasil.

Conforme escrevemos linhas atrás, as regras de subcapitalização foram estabelecidas no Brasil com base em critério quantitativo fixo e predeterminado, com total abstração do princípio arm's length, ${ }^{228}$

Por seu turno, determina a convenção modelo da OCDE, nos comentários relativos ao artigo 9 (parágrafo $1^{\circ}, 3, c$ ), que a aplicação de regras domésticas de subcapitalização não deve implicar em ônus (ou receita tributável) superior ao que seria observado segundo o princípio arm's lenght. ${ }^{229}$

Desta forma, concordamos com Alberto Xavier que afirma que as regras brasileiras de subcapitalização não são compatíveis com o $\operatorname{artigo} 9^{\circ}$ da Convenção Modelo da OCDE. $^{230}$

Adicionalmente, também observamos que as regras brasileiras de subcapitalização tratam de forma diferenciada o endividamento com credores residentes e não residentes no país, não admitindo quanto aos financiamentos prestados por estes, a dedutibilidade dos juros na parte considerada em excesso.

Por sua vez, os comentários ao artigo 24 (parágrafo $4^{\circ}$ ) proíbem claramente a distinção de tratamento entre juros pagos a credores residentes e não residentes nas mesmas condições ${ }^{231}$, e novamente concordamos com Alberto Xavier que afirma que o regime de subcapitalização adotado no Brasil não é compatível com o artigo 24 da Convenção Modelo da OCDE. ${ }^{232}$

Cumpre observar que os tratados celebrados com África do Sul, Chile, Israel, Peru e Portugal consagram em protocolos declaração de que as convenções não impedem os

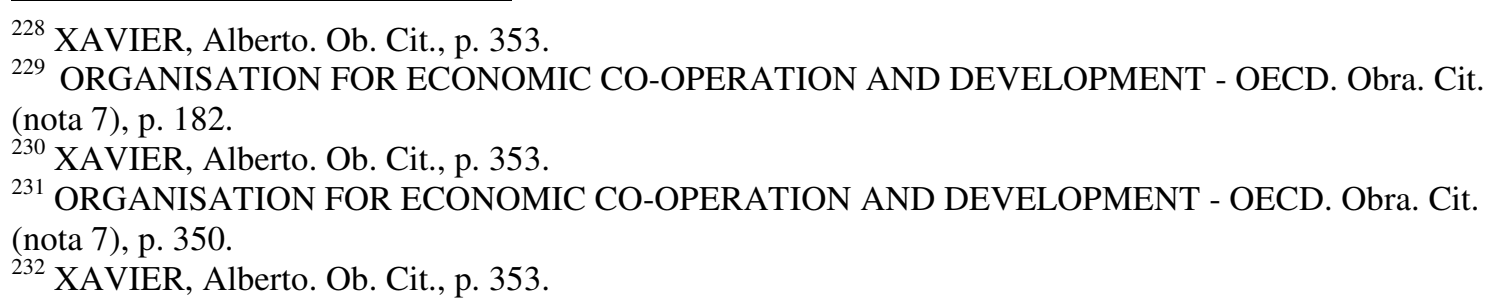


Estados contratantes de aplicas às disposições das respectivas leis internas sobre subcapitalização.

Desta forma, tendo em vista a incompatibilidade das regras brasileiras de subcapitalização com as disposições da convenção modelo, especialmente no que se refere aos artigos $9^{\circ}$ e $24^{\circ}$, pode-se concluir que nos casos em que não haja uma ressalva expressa no tratado celebrado pelo Brasil quanto à aplicação das regras de subcapitalização, pode ser invocada a incompatibilidade entre a convenção modelo e as referidas regras.

\subsection{Subcapitalização como norma tributária indutora}

Tema bastante explorado não apenas na doutrina brasileira, mas principalmente na doutrina estrangeira, a análise do efeito indutor nas normas tributárias e a intervenção econômica vêm ganhando cada vez mais espaço na doutrina e nos debates acadêmicos tendo como grande expoente no Brasil, o Professor Luís Eduardo Schoueri que é autor de obra que tratou de maneira extensa e profunda do tema, intitulada: Normas Tributárias Indutoras e Intervenção Econômica.

O tema ganha relevância na medida em o Estado não mais atua como mero vigilante de uma economia que se autorregula, mas passa a prevalecer o modelo a partir do qual o Estado desempenha um papel ativo e permanente nas realizações inseridas no campo econômico. $^{233}$

Jacques Généreux, autor francês dedicado ao estudo da economia, afirma que a lógica intervencionista, largamente difundida pelos trabalhos de John Maynard Keynes (1883-1946), parte de um postulado inverso ao das economias liberais (clássicos e neoclássicos): a livre negociação de preços não garante o equilíbrio automático de todos os mercados. $^{234}$

\footnotetext{
${ }^{233}$ SCHOUERI, Luís Eduardo. Normas Tributárias indutoras e intervenção econômica. Rio de Janeiro: Forense, 2005, p. 1.

${ }^{234}$ GÉNÉREUX, Jacques. Introdução à política econômica. Tradução Maria Stela Gonçalves e Adail Ubirajara Sobral. São Paulo: Editora Loyola, 1995, p. 45.
} 
Diante desse novo modo de ver a economia, verifica-se que problemas como inflação, desemprego, desequilíbrio na balança comercial, dentre outros, não são fenômenos temporários rapidamente superados pelos ajustes de preços; pelo contrário, são desequilíbrios persistentes que justificam intervenções corretivas do Estado. ${ }^{235}$

Ampliando o horizonte da análise, verifica-se que além das ações corretivas citadas por Jacques Généreux, no sentido de ajustar eventuais desequilíbrios, o Estado passa a utilizar a intervenção econômica para concretização de objetivos maiores, como reduzir desigualdades sociais e regionais, erradicar pobreza e marginalização e buscar o desenvolvimento nacional. Podemos registrar como marcos dessa mudança de atuação, no plano internacional a Constituição do México de 1917 e o texto de Weimar na Alemanha em 1919 e, no plano nacional, a Constituição Brasileira de 1934.

Nesta linha, Gilberto Bercovici esclarece:

com o advento do chamado Estado Social, governar passou a não ser mais a gerência de fatos conjunturais, mas, também, e sobretudo, o planejamento do futuro, com o estabelecimento de políticas de médio e longo prazo. (...) O Direito Constitucional acompanhou as mudanças políticas, sociais e econômicas. As Constituições liberais do século XIX tinham como fundamento a separação entre Estado e sociedade, sendo seu objetivo máximo a limitação do poder estatal. Com o advento do Estado Social, as Constituições do século XX, incorporaram em seus textos o conflito existente entre as forças sociais, buscando abranger toda uma nova série de direitos e matérias. ${ }^{236}$

Diante dessa nova realidade, torna-se relevante a relação entre o direito e a economia, pois enquanto a ciência econômica tenta encontrar soluções para a carência de recursos para a sociedade, a ciência jurídica deve servir de instrumento de harmonização nas relações sociais, limitando as liberdades, tutelando os direitos e garantias individuais e os interesses coletivos. ${ }^{237}$

\footnotetext{
${ }^{235}$ GÉNÉREUX, Jacques. Ob. Cit., p. 45.

${ }^{236}$ BERCOVICI, Gilberto. Constituição Econômica e desenvolvimento: uma leitura a partir da Constituição de 1988. São Paulo: Malheiros Editores, 2005, p. 57-58.

${ }^{237}$ ELALI, André de Souza Dantas. Tributação e regulação econômica: um exame da tributação como instrumento de regulação econômica na busca da redução das desigualdades. São Paulo: MP Editora, 2007, p. 17.
} 
Por fim, Diógenes Gasparini lembra que os atos e medidas de intervenção hão de respeitar os princípios constitucionais que se conformam com o Estado Democrático de Direito, consignado expressamente em nossa Lei Maior. ${ }^{238}$

Considerando os comentários acima e a nova postura do Estado, pode-se indagar se as normas de subcapitalização, enquanto normas tributárias, caracterizam-se como norma tributária indutora ou não.

Antes de responder a essa indagação, cabe breve digressão se o direito tributário permite o estabelecimento de normas tributárias indutoras e em que medida.

Nesse sentido, Vitor Polizelli ao tratar da progressividade, distribuição de renda e indução anotou que o direito tributário não se apresenta como um sistema fechado dedicado apenas a finalidade de arrecadação de recursos para o Estado e, portanto, incólume à influência dos demais objetivos previstos pelo ordenamento jurídico.

Desta forma, uma análise funcional do sistema tributário integra-o aos demais conjuntos de princípios e regras adotados na ordem jurídica, reconhecendo-se as suas características de extrafiscalidade no atendimento dos valores constitucionalmente estabelecidos para a obtenção de efeitos econômicos, políticos e sociais. ${ }^{239}$

A admissão das características de extrafiscalidade do direito tributário para a obtenção de efeitos econômicos, políticos e sociais torna-se relevante na medida em que se observa, presentemente, intenso movimento do governo no desenvolvimento de políticas econômicas por meio de estabelecimento de normas tributárias como, por exemplo, as diversas alterações observadas no Imposto sobre operações de crédito, câmbio e seguro, ou relativas a títulos ou valores mobiliários (conhecido como IOF) incidente sobre empréstimos externos. ${ }^{240}$

\footnotetext{
${ }^{238}$ GASPARINI, Diogenes. Direito Administrativo. 5 ed., ver. atual. e aum. São Paulo: Saraiva, 2000, p. 596. ${ }^{239}$ POLIZELLI, Vitor Borges. "Progressividade: Distribuição de Renda e Indução". In Direito Tributário Atual, vol. 21, 2007, p.368.

${ }^{240}$ Em um intervalo de aproximadamente um ano, as disposições do Decreto 6.306/07 (regulamento do IOF) relativas a empréstimos externos foram alteradas 3 vezes.
} 
Fernando Aurélio Zilveti também tratou da extrafiscalidade do direito tributário, especialmente do IOF ao afirmar que no IOF, o Estado faz uso da progressividade regressiva, quando trata da alíquota incidente sobre os contratos de empréstimos internacionais, destinando a maior alíquota aos de curto prazo, normalmente utilizados para atividades circunstanciais e especulativas, e isentando aqueles de longo prazo, que se destinam a financiar setores da economia privada. ${ }^{241}$

Considerando todos os comentários acima, parece razoável afirmar que as normas de subcapitalização possuem caráter indutor, na medida em que ao limitar o endividamento das empresas ou limitar a dedutibilidade dos juros pagos, há claramente a intensão de desestímulo ao financiamento via endividamento contraído com os próprios sócios ou terceiros não relacionados (debit) e estímulo ao aporte de capital propriamente dito por parte dos sócios (equity).

${ }^{241}$ ZILVETI, Fernando Aurélio. Princípios de direito tributário e a capacidade contributiva. São Paulo: Quartier Latin, 2004, p. 179. 
6. Crítica às regras de subcapitalização adotadas no direito brasileiro e sugestões de melhorais com base no direito comparado

Realizada a contextualização histórica, bem como superada a fase conceitual do trabalho, onde buscamos discorrer sobre os principais conceitos ligados à subcapitalização, tanto no plano internacional quanto no plano nacional, realizando críticas pontuais quanto alguns aspectos das regras estabelecidas no Brasil, avançamos para a reflexão acerca da norma como um todo, afim de que se avalie a necessidade da norma, sua eventual caracterização como norma antielisiva específica, bem como outros aspectos específicos que julgamos merecedores de análise, críticas e sugestões de melhoria.

\section{1 (Des) Necessidade da norma}

Como dissemos no capítulo 5, a Medida Provisória $\mathrm{n}^{\circ} 472$ (posteriormente convertida na Lei $n^{o}$ 12.249) dispôs sobre os limites de dedutibilidade dos juros na apuração do lucro real e da base de cálculo da contribuição social sobre o lucro líquido.

Os artigos 24 e 25 da referida medida provisória definiram que os juros pagos ou creditados por fonte situada no Brasil à: i) pessoa física ou jurídica vinculada e residente ou domiciliada no exterior, bem como à ii) pessoa física ou jurídica residente, domiciliada ou constituída no exterior em país ou dependência com tributação favorecida ou sob regime fiscal privilegiado; somente seriam dedutíveis se observados determinados limites e condições e, caso não fossem observados os limites de endividamento e condições estabelecidos na norma, a despesa seria considerada não necessária à atividade da empresa, conforme definido no art. 47 da Lei $n^{\circ} 4.506 / 64$.

Segundo a exposição de motivos que acompanhou a Medida Provisória no 472/09, mais do que impor limites à dedutibilidade dos juros na apuração do lucro real e da base de calculo da contribuição social sobre o lucro líquido, as normas brasileiras contra a subcapitalização visaram evitar a erosão da base de cálculo dos referidos tributos, mediante endividamento abusivo. 
Em que pese a aparente relevância dos argumentos colocados na exposição de motivos, bem como as sérias implicações da não observância dos limites impostos pelos artigos 24 e 25 da Lei $n^{\circ} 12.249 / 10$, se questiona, após a análise do sistema jurídico anterior a introdução das referidas normas, a real necessidade da norma.

O questionamento acerca da (des) necessidade da norma se dá pelo entendimento que os dispositivos existentes no ordenamento jurídico, previamente ao estabelecimento das referidas regras, já seriam suficientes para desempenhar o papel pretendido pelo legislador ao estabelecer as regras contra a subcapitalização, especialmente as figuras da despesa necessária e dos juros sobre o capital próprio que passamos a analisar em mais detalhes.

\subsubsection{Conceito de despesa necessária antes e depois da norma}

Como dissemos no item 5.2.1.1, pode-se afirmar que, com o estabelecimento das regras de subcapitalização no Brasil, os juros pagos ou creditados por fonte situada no Brasil à pessoa física ou jurídica vinculada e residente ou domiciliada no exterior, bem como à pessoa física ou jurídica residente, domiciliada ou constituída no exterior em país ou dependência com tributação favorecida ou sob regime fiscal privilegiado, somente serão considerados despesas necessárias e, portanto, dedutíveis na apuração do lucro real e da base de cálculo da CSLL, até os limites estabelecidos nos artigos 24 e 25 da Lei $n^{\circ}$ 12.249/10.

Por seu turno, os juros pagos ou creditados, ainda que se amoldem ao conceito trazido pelo artigo 47 da Lei 4.506/64, mas excedentes aos limites estabelecidos nos artigos 24 e 25 da Lei n ${ }^{\circ}$ 12.249/10, não serão dedutíveis na apuração do lucro real e da base de cálculo da CSLL, pois serão considerados despesas não necessárias.

O que se questiona neste ponto é se o próprio artigo 47 da Lei 4.506 , que desde 1964 traz o conceito de despesa necessária, já não seria suficiente para definir o limite que separa uma despesa necessária à atividade da empresa e uma despesa exagerada com o pagamento de juros ou, em outras palavras, uma despesa não necessária e, portanto, não 
dedutível para fins de apuração do lucro real e da base de cálculo da contribuição social sobre o lucro líquido.

Ricardo Mariz, ao analisar as limitações à dedutibilidade de remunerações de dirigentes afirma de maneira veemente que todas as disposições que buscam restringir a dedutibilidade de custos ou despesas carregam vesgo de anacronismo e injuridicidade. ${ }^{242}$

Anacronismo na medida em que as disposições legais impeditivas de deduções datam de épocas antigas, quando o cenário empresarial era totalmente diferente do atual. ${ }^{243}$

Neste ponto, ainda que as regras contra a subcapitalização tenham sido estabelecidas recentemente no Brasil, o comentário de Ricardo Mariz mostra-se também aplicável, visto que os limites impostos não observam o cenário empresarial atual, pois diversos fatores, a começar pela globalização descrita nas páginas iniciais do presente trabalho, podem justificar um alto nível de endividamento.

Quanto à injuridicidade, observa Ricardo Mariz que esta eventuais evasões devem ser combatidas caso a caso, com provas seguras da sua ocorrência e a devida penalização de seus autores, e não através de normas gerais e injustas, que atingem todos os contribuinte e que não se preocupam em distinguir casos de deduções legítimas dos fraudulentos. $^{244}$

Novamente observamos a adequação dos comentários de Ricardo Mariz ao contexto da subcapitalização, pois a norma atinge todos os contribuintes e não se preocupa em distinguir situações específicas que justificariam um endividamento maior.

Entre as situações especificas que poderiam justificar um nível de endividamento maior, podemos citar uma empresa em fase pré-operacional que ainda não tem caixa suficiente para fazer frente as suas necessidades imediatas ou ainda uma empresa em dificuldades financeiras que eleva o nível de empréstimos para enfrentar um período mais crítico de liquidez e, superada essa fase, volta a sua atividade normal e, consequentemente,

\footnotetext{
242 OLIVEIRA, Ricardo Mariz de. Ob. Cit. p. 407.

${ }^{243}$ OLIVEIRA, Ricardo Mariz de. Ob. Cit. p. 407.

${ }^{244}$ OLIVEIRA, Ricardo Mariz de. Ob. Cit. p. 408.
} 
reduz o seu nível de endividamento. Podemos citar ainda situações de mercado que afetam as empresas em geral, como crises econômicas globais, como a crise verificada em 2008 e 2009, após a quebra da Lehman Brothers, ocorrida em setembro de $2008 .^{245}$

Neste sentido, podemos afirmar que questões como governança de caixa e outros motivos de administração, ou ainda o momento econômico do país ou mundial, poderiam justificar um endividamento maior e, nestas situações, não necessariamente a dita subcapitalização visaria um benefício fiscal.

É nesse ponto que reside à crítica a necessidade da norma, pois em nosso entendimento, o conceito de despesa necessária existente anteriormente à Lei ${ }^{\circ}$ 12.249/10 já era suficiente para distinguir as situações e despesas que efetivamente tinham o viés de buscar benefício fiscal exagerado ou indevido e situações em que havia real necessidade do endividamento.

A afirmação acima é confirmada pela existência de autos de infração e discussões administrativas/judiciais anteriores às regras de subcapitalização como, por exemplo, o caso Colgate-Kolynos referido no item 4.4, onde a fiscalização concluiu que nos anoscalendário de 1996, 1997 e 1998, a empresa infringiu o disposto no artigo 242 do Regulamento do Imposto de Renda de 1994 (atual artigo 299 do Regulamento de 1999), resultando em matéria tributável a título de "custo, despesas operacionais e encargos não necessários".

O caso é complexo e já foi explicado em detalhes no item 4.4, mas vale ressaltar que as discussões foram intensas em torno do limite de pagamento de juros, juros sobre capital próprio x subcapitalização, dentre outros temas e foram realizadas exclusivamente em função do conceito de despesa necessária, sem a necessidade de regra específica de subcapitalização.

Nesta linha, observa Nereida de Miranda Finamore Horta que, em relação ao pagamento de juros, antes do advento da nova regra, poderíamos inferir que seria considerada despesa necessária quando a empresa estivesse em situação de escassez de

\footnotetext{
${ }^{245}$ O tema foi amplamente divulgado na mídia e há farta leitura a seu respeito, por outro lado, por não se
} mostrar pertinente ao presente trabalho, não aprofundaremos os comentários. 
recursos próprios para investir ou tocar seus negócios, ou, simplesmente se assim designasse sua política financeira implementada dentro do preceito de boa governança corporativa e, pelo ingrediente subjetivo dessa norma, comprovar a necessidade da espessa para atividade da empresa ou de sua fonte pagadora poderia ser aceito por uns, mas por outros não, a depender do caso concreto. ${ }^{246}$

Desta forma, não nos parece razoável a limitação da dedutibilidade dos juros em função de determinado patamar objetivo de endividamento, adotando-se a premissa que qualquer despesa excedente ao referido patamar não é necessária à atividade da empresa e, portanto, não é passível de dedução na apuração do lucro real e base de cálculo da contribuição social sobre o lucro líquido.

\subsubsection{Juros sobre o capital próprio - JCP}

Antes de avançarmos sobre os propósitos do estabelecimento dos juros sobre o capital próprio - JCP cumpre-nos realizar breve esclarecimento acerca da natureza jurídica deste instituto.

De imediato, observamos divisão doutrinária antiga em dois blocos distintos: autores que propõe que a figura dos juros sobre o capital próprio tem natureza jurídica de dividendos e autores que defendem que a referida figura tem natureza jurídica de juros.

Dentre os defensores da natureza jurídica de dividendos, destacamos Alberto Xavier, que afirma que a determinação da verdadeira natureza jurídica desse instituto tem sido dificultada pela manifesta impropriedade da expressão “juros sobre o capital próprio", visto que a remuneração que a pessoa jurídica paga ao seu titular, sócio ou acionista não tem a natureza de juro, pela singela razão que o conceito de juro é reservado a remunerações direta ou indiretamente referidas à concessão de crédito, assim entendidas aquelas em que existe uma obrigação de restituição de somas entregues a título de antecipação, não sendo esse o caso do instituto em comento. ${ }^{247}$

\footnotetext{
${ }^{246}$ HORTA, Nereida de Miranda Finamore. Ob Cit., p. 288.

${ }^{247}$ XAVIER, Alberto. Ob. Cit. p. 499.
} 
Nesse sentido, afirma o autor que o JCP outra coisa não é que um resultado distribuível da companhia, sujeito a regime especial, resultado este suscetível de duas destinações alternativas de distribuição efetiva aos sócios ou capitalização: i) imediata, por via de aumento de capital ou; ii) futura, por via de manutenção de reserva destinada a futuro aumento de capital. No primeiro caso, ocorre a figura do dividendo, regulada nos artigos 201 e seguintes da lei das S.A.; no segundo, ocorre a figura do aumento de capital por capitalização de lucros ou reservas prevista no art. 169 da mesma Lei. ${ }^{248}$

Confirmaria essa linha de raciocínio o disposto no parágrafo $7^{\circ}$ do art. $9^{\circ}$ da Lei $n^{\circ}$ 9.249/95 que estabelece que o valor dos juros pagos ou creditados a pessoa jurídica, a título de remuneração de capital próprio, poderá ser imputado ao valor dos dividendos de que trata o art. 202 da Lei 6.404, de 15 de dezembro de 1976. Em outras palavras, se o valor dos "juros" pode ser imputado ao dividendo obrigatório, isso significa que eles próprios têm a natureza substancial de dividendo.

Por seu turno, há autores que defendem que o JCP se aproxima da figura dos juros, como é o caso de João Dácio Rolim que afirma que os juros sobre o capital próprio possuem natureza de juros propriamente ditos, pois remuneram o sócio pelo capital investido na sociedade e, portanto, indisponível para a realização de outros investimentos, bem como são tratados como receita ou despesa financeira para fins fiscais. ${ }^{249}$

O Superior Tribunal de Justiça - STJ também já se manifestou na mesma linha defendida por João Dácio Rolim e em julgamento realizado em 2010 afirmou o relator que o tribunal já firmou entendimento consolidado no sentido que o JCP não tem natureza de dividendo, pelo contrário, aproxima-se da figura receita financeira e, consequentemente, aproxima-se da noção de juros. ${ }^{250}$

Adotando linha diferente das duas anteriormente citadas, observamos que Fábio Ulhôa Canto refutou a equiparação do JCP aos dividendos e não o classificou como juros,

\footnotetext{
${ }^{248}$ XAVIER, Alberto. Ob. Cit. p. 499.

${ }^{249}$ ROLIM, João Dácio. “A remuneração do capital próprio das pessoas jurídicas e a revogação da correção monetária de balanço pela Lei no 9.249/95”. In Repertório IOB de jurisprudência, $n^{\circ} 16,2$ quinz. ago. São Paulo: 1996, p. 392.

${ }^{250}$ Superior Tribunal de Justiça, Agravo Regimental no Recurso Especial no 1.158.033/RS, Quarta Turma, Relator Ministro Luis Felipe Salomão, julgamento em 16.09.2010, DJ de 22.09.2010.
} 
mas afirmou o JCP é um tipo de remuneração dos acionistas, feita em razão do investimento que eles realizam na atividade empresarial explorada pela companhia pagadora; mas uma remuneração diferente dos dividendos e, desta forma, a remuneração dos sócios da sociedade anônima, em razão do investimento, deve ser classificada em duas espécies: uma delas continua sendo a participação nos lucros da companhia e a outra é o pagamento dos juros. ${ }^{251}$

O autor faz interessante observação, entretanto não aprofunda o estudo para definir o alcance e importância da análise da natureza jurídica deste instituto.

Outra vez nos socorremos das lições de Luís Eduardo Schoueri que segue linha semelhante à linha de Fábio Ulhôa Canto, ao afirmar que os juros sobre o capital próprio não podem ser equiparados aos dividendos tão pouco aos juros, mas adota fundamentação diferenciada para essa conclusão, bem como aprofunda o estudo para efetivamente concluir qual é a natureza jurídica desta figura.

Observa o autor que há um ponto comum nos debates doutrinários acerca da natureza dos juros sobre o capital próprio, qual seja, todos os debates tomam por ponto de partida a premissa de que a natureza do instituto deve, necessariamente, ancorar-se em conceitos pré-existentes e já qualificados no âmbito do Direito Privado, a exemplo de dividendos e juros. $^{252}$

Ante essa constatação, indaga Luís Eduardo Schoueri se o Direito Tributário, necessariamente, deve se valer dos conceitos de Direito Civil e, em resposta, afirma que a doutrina da consideração econômica, que tanta influência exerceu sobre aqueles que elaboraram o código tributário nacional, reconhece a possibilidade de o legislador não empregar conceitos de Direito Privado, mas conceitos de natureza diversa (conceitos

\footnotetext{
${ }^{251}$ CANTO, Fabio Ulhoa. "A participação nos resultados das Companhias (Dividendos e Juros sobre o Capital Próprio) e os Direitos dos Acionistas Minoritários". In Aspectos atuais do direito do mercado financeiro e de capitais. $2^{\circ}$ Volume. São Paulo: Dialética, 2000, p. 41.

${ }^{252}$ SCHOUERI, Luís Eduardo. "Juros sobre Capital Próprio: Natureza jurídica e forma de apuração diante da 'nova contabilidade"”. In: MOSQUERA, Roberto Quiroga e LOPES, Alexsandro Broedel (coord.). Controvérsias jurídico-contábeis (aproximações e distanciamentos). $3^{\circ}$ Vol. São Paulo: Dialética, 2012, p.179.
} 
econômicos). Em tal circunstancia desnecessário buscar, no Direito Privado, a natureza jurídica do instituto. ${ }^{253}$

"Desta forma, afastando-se qualquer aproximação com categorias de Direito Privado, há que se reconhecer que, na perspectiva do Direito Tributário, corresponde a figura do artigo $9^{\circ}$ da Lei ${ }^{\circ}$ 9.249/95 a uma remuneração do capital". ${ }^{254}$

Mariana Miranda Lima em sua dissertação de mestrado apresentada à Universidade de São Paulo segue linha semelhante e afirma que os juros sobre o capital próprio destinam-se a remunerar os sócios pelo capital próprio investido e observa que há tratamento tributário e contábil específico dispensado a essa figura, o que justifica não ser possível equipara-la aos dividendos ou aos juros. ${ }^{255}$

Com o devido respeito às posições firmadas por relevantes juristas que defendem a equiparação do JCP às figuras de dividendos ou juros, nos parece assistir razão a Luís Eduardo Schoueri e Mariana Miranda Lima, no sentido de se tratar de uma figura nova e com regramento próprio, sendo um instituto estabelecido com uma clara finalidade: remunerar os sócios pelo capital próprio investido na sociedade.

Avançando no raciocínio, interessante observar outra característica do JCP: de acordo com o artigo $9^{\circ}$ da Lei 9.249/95, o JCP é dedutível na apuração do lucro real (até os limites especificados na própria norma), em igualdade de tratamento, sob o ponto de vista fiscal, com a remuneração do capital de terceiros ou, em outras palavras, significa dizer que o instituto criado para remunerar os sócios ou acionistas, permite a estes perceber um rendimento equivalente ao que receberia se buscasse, por exemplo, um investimento bancário, não medida em que são equiparados os tratamentos tributários dos juros.

Observa Luís Eduardo Schoueri que a natureza da remuneração do capital emprestada ao instituto constante do artigo $9^{\circ}$ da Lei $n^{\circ} 9.249 / 95$ permite que se concretizem exigências do principio da igualdade e da capacidade contributiva na medida em que permite que as empresas que se valem de recursos de seus próprios sócios ou

\footnotetext{
253 SCHOUERI, Luís Eduardo. Ob. Cit. (nota 252), p. 181.

${ }^{254}$ SCHOUERI, Luís Eduardo. Ob. Cit. (nota 252), p. 182.

${ }^{255}$ LIMA, Mariana Miranda. Ob. Cit., p. 101-102.
} 
acionistas, tomem a dedutibilidade dos valores pagos enquanto remuneração do referido capital, reestabelecendo a igualdade destes em relação a contribuintes que, com igual capacidade econômica, façam uso de capital emprestado por terceiros, visto que os juros remuneratórios do capital emprestado são admitidos como dedutíveis, desde que considerados necessários à atividade da empresa, como visto no item 2.2.3. ${ }^{256}$

Desta forma, por meio dos juros sobre capital próprio, assegura-se igual tratamento tributário à atividade empresarial, afastando-se a diferenciação por conta da origem de seu capital (próprio ou de terceiros). ${ }^{257}$

Como observamos no item 4.3, a exposição de motivos do projeto de lei que resultou na Lei no 9.249/95 já deixava clara a finalidade da criação do instituto, qual seja, a equiparação do tratamento fiscal dispensado aos diversos tipos de rendimentos do capital, provando um incremento das aplicações produtivas nas empresas brasileiras, capacitandoas a elevar o nível de investimentos, sem endividamento, com evidentes vantagens no que se refere à geração de empregos e ao crescimento sustentado da economia.

Luís Eduardo Schoueri faz interessante observação ao afirmar que do ponto de vista do investidor, também se concretiza a igualdade, naquilo que se equiparam ambas as situações e, se é verdadeira a premissa de que do lucro obtido na atividade empresarial, uma parte corresponde à remuneração do capital e outra, à atividade produtiva, então não há razão para a remuneração do capital proveniente de aplicações financeiras ter tratamento diferente daquele mesmo capital investido na empresa. ${ }^{258}$

A partir desta premissa é que surge a tributação na fonte que à época da edição da Lei $n^{\circ}$ 9.249/95 era de $15 \%$ para as aplicações financeiras de renda fixa o que explica a alíquota aplicável aos juros sobre o capital próprio e hoje, mesmo com a mudança da tributação das aplicações financeiras promovida pela Lei $\mathrm{n}^{\circ} 11.033 / 04$, ainda se tem a alíquota de $15 \%$ para aplicações a longo prazo, justificando-se, igualmente, a tributação

\footnotetext{
${ }^{256}$ SCHOUERI, Luis Eduardo. Ob. Cit. (nota 252), p. 184.

${ }^{257}$ SCHOUERI, Luis Eduardo. Ob. Cit. (nota 252), p. 184.

${ }^{258}$ SCHOUERI, Luis Eduardo. Ob. Cit. (nota 252), p. 184.
} 
dos juros sobre capital próprio em nível equivalente a aplicações financeiras de longo prazo. $^{259}$

Todo o racional desenvolvido até agora nos permite concluir que o benefício fiscal buscado pelo endividamento (excessivo ou não), qual seja, a dedução da despesa com juros na base de cálculo do imposto sobre renda, bem como uma tributação de fonte definida e em patamares aceitáveis, é integralmente atingido por meio dos juros sobre o capital próprio, o que leva ao questionamento sobre a real necessidade do estabelecimento das regras de subcapitalização, visto que a existência do JCP já cumpria referida função.

Referida opinião é compartilhada por Luís Eduardo Schoueri que diz causar estranheza a importação de regras de subcapitalização em 2009, já que a regra dos juros sobre o capital próprio já constituía expediente suficiente para desestimular a prática da subcapitalização, já que o máximo que se buscaria seria a dedutibilidade de juros de empréstimos tomados; entretanto tal dedutibilidade já tinha sido assegurada 15 anos antes

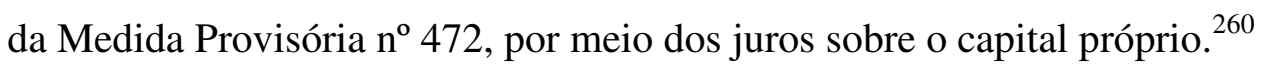

Em que pese o trabalho de Mariana Miranda Lima ser anterior ao estabelecimento das regras de subcapitalização, a autora já observava que a partir do momento em que é possível remunerar o capital próprio investido na sociedade por meio de rendimento sujeito a tratamento tributário equiparado àqueles dos juros de empréstimos, não há mais que se falar da justificativa para a prática do que denominou de subcapitalização nominal. ${ }^{261}$

Considerando os comentários realizados até aqui acerca das regras existentes à época da edição das normas de subcapitalização, especialmente as concernentes às despesas necessárias e aos juros sobre o capital próprio, bem como os comentários de Luís Eduardo Schoueri e de Mariana Miranda Lima, ficamos convincentes que não havia necessidade de estabelecimento de regras de subcapitalização no Brasil.

\footnotetext{
${ }^{259}$ SCHOUERI, Luis Eduardo. Ob. Cit. (nota 252), p. 185.

${ }^{260}$ SCHOUERI, Luis Eduardo. Ob. Cit. (nota 252), p. 173.

${ }^{261}$ LIMA, Mariana Miranda. Ob. Cit., p. 81.
} 


\subsubsection{Norma antielisiva específica}

Segundo a exposição de motivos que acompanhou a Medida Provisória no 472/09, referido normativo tem por finalidade aprimorar a legislação tributária vigente, eliminando algumas formas abusivas de planejamento fiscal bem como evitando a erosão da base de cálculo do Imposto de Renda da Pessoa Jurídica e da Contribuição Social sobre o Lucro Líquido mediante endividamento abusivo.

\section{Vejamos o texto:}

"Excelentíssimo Senhor Presidente da República,

Temos a honra de submeter à apreciação de Vossa Excelência o Projeto de Medida Provisória que: (...)

i) aprimora a legislação tributária vigente eliminando algumas formas abusivas de planejamento fiscal. Também visa adequar alguns dispositivos legais de forma a corrigir distorções existentes na forma de tributação e no tratamento fiscal.

29. O art. 24 visa evitar a erosão da base de cálculo do IRPJ e da CSLL mediante o endividamento abusivo realizado da seguinte forma: a pessoa jurídica domiciliada no exterior, ao constituir subsidiária no País, efetua uma capitalização de valor irrisório, substituindo o capital social necessário à sua constituição e atuação por um empréstimo, que gera, artificialmente, juros que reduzem os resultados da subsidiária brasileira.

29.1. A dedução desses juros da base de cálculo do IRPJ (alíquota de 15\% mais adicional de 10\%) e da CSLL (alíquota de 9\%) gera uma economia tributária de 34\% do seu valor. Mesmo considerando que as remessas para pagamento de juros são tributadas pelo Imposto sobre a Renda Retido na Fonte (IRRF) à alíquota de $15 \%$, resta uma economia tributária de $19 \%$.

29.2. A medida torna os juros considerados excessivos indedutíveis, segundo critérios e parâmetros legais. O objetivo é controlar o endividamento abusivo junto a pessoa vinculada no exterior, efetuado exclusivamente para fins fiscais

30. O art. 25 segue o mesmo princípio do art. 24, entretanto, é aplicado na hipótese de a pessoa jurídica domiciliada no Brasil contrair empréstimos com pessoa jurídica domiciliada em país ou dependência com tributação favorecida, ou que goze de regime fiscal privilegiado. Da mesma forma, esses empréstimos geram juros que reduzem, artificialmente, o resultado tributável no Brasil e, ao mesmo tempo, geram lucros que não serão tributados de maneira representativa no exterior. A medida restringe a dedutibilidade das despesas de juros de pessoas jurídicas residentes no Brasil quando pagos a entidades "off-shore", independentemente de vínculo societário."

Tendo por base a objetividade que o tema foi colocado na exposição de motivos, bem como o próprio texto dos artigos 24 e 25 da Medida Provisória, posteriormente convertida em Lei, não é difícil encontrar quem argumente que as regras de subcapitalização foram estabelecidas no Brasil como uma norma antielisiva específica, o que novamente nos leva a refletir sobre a real necessidade da norma.

Não pretendemos discorrer de maneira detalhada acerca de temas como planejamento tributário, elisão fiscal, evasão fiscal e normas antielisivas; por outro lado, 
entendemos que alguns breves comentários acerca destes temas são necessários para a conclusão a que se pretende chegar, qual seja, não havia necessidade de publicação de regras de subcapitalização para limitar o endividamento excessivo, visto que a regra de despesas necessárias, bem como do instituto dos juros sobre o capital próprio, já se mostravam suficientes para atingir o objetivo proposto pela exposição de motivos que acompanhou a medida provisória $n^{\circ} 472 / 09$.

Em trabalho bastante relevante sobre o tema Elisão e Evasão Fiscal, Antônio Roberto Sampaio Dória já escrevia em 1971 que elisão fiscal tem legitimidade jurídica, pois enquanto não se realiza in concreto a hipótese de incidência, enquanto o fato gerador está latente ou potencial, não terá cabimento que o fisco pretenda direito à percepção de tributo. $^{262}$

Prossegue o autor afirmando que se pela elisão fiscal o fato gerador não chega a se manifestar, porquanto o contribuinte, que visava certo resultado econômico, foi suficientemente hábil na estruturação de seu negócio, afastando-se do protótipo previsto na norma, então a obrigação fiscal não se instaura por estar ainda em sua primeira etapa, de caráter abstrato. $^{263}$

Desta forma, o autor utiliza os termos evasão ou fraude para exprimir a ação tendente a eliminar, reduzir ou retardar o pagamento do tributo devido; e elisão ou economia fiscal, para exprimir ação tendente a evitar minimizar ou adiar a ocorrência do próprio fato gerador. ${ }^{264}$

Olhando para a divisão realizada por Antônio Roberto Sampaio Dória, nos parece que qualquer discussão acerca do tema planejamento tributário, como referido na exposição de motivos em comento, deveria tratar exclusivamente da figura elisão, visto que a chamada evasão deve ser tratada de forma severa, pois adota contornos de ilegalidade.

${ }^{262}$ DÓRIA, Antônio Roberto Sampaio. Elisão e Evasão Fiscal. São Paulo: Livraria dos Advogados Editora Ltda, 1971, p. 53.

${ }^{263}$ DÓRIA, Antônio Roberto Sampaio. Ob. Cit., p. 53.

${ }^{264}$ DÓRIA, Antônio Roberto Sampaio. Ob. Cit., p. 25. 
Observa Elidie Palma Bifano que a expressão ou designação "planejamento tributário" assumiu, nos últimos tempos, uma conotação muito pouco desejável na medida em que é, de imediato, relacionada a operações não autorizadas em lei ou que permitem resultados não admitidos pela lei. Essa automática associação de planejamento tributário a transações despidas de causa jurídica, transparência e substância econômica não merece prosperar. $^{265}$

As razões para mudar a conotação atual parecem ser simples, pois são determinadas pelo próprio sistema jurídico vigente, na medida em que o contribuinte tem o direito de planejar seus negócios de forma a economizar tributos, observadas as determinações legais, como se pode depreender da leitura do artigo 153 da Lei 6.404/76: ${ }^{266}$

Art. 153. O administrador da companhia deve empregar, no exercício de suas funções, o cuidado e diligência que todo homem ativo e probo costuma empregar na administração de seus próprios negócios

Cumpre destacar o verbo empregado no dispositivo legal: "deve", em outras palavras, o administrador tem obrigação de empregar a administração mais eficiente possível aos seus negócios, não havendo dúvidas que a busca pela economia de tributos, desde que observados preceitos legais, se enquadra perfeitamente no conceito de administração eficiente do negócio.

Os limites do planejamento tributário são intensamente discutidos na doutrina, não cabendo aqui discorrermos sobre as diferentes teorias, mas algo parece certo e comum a todas as teorias: o contribuinte não deve se valer de meios ilícitos para a execução do planejamento tributário.

A exposição de motivos que acompanhou a medida provisória $n^{\circ} 472 / 09$ se refere às formas abusivas de planejamento fiscal, nos parecendo inadequada a expressão, na medida em que todo planejamento tributário que leve à elisão, nos termos descritos por Antônio Roberto Sampaio Dória, e que não se utilize de meios ilícitos para ser executado, estaria dentro do licitude e em consonância com o artigo 153 acima referido.

\footnotetext{
${ }^{265}$ BIFANO, Elidie Palma. Ob. Cit., p. 125.

${ }^{266}$ BIFANO, Elidie Palma. Ob. Cit., p. 126.
} 
Conjugando-se todos os comentários realizados neste item, podemos dizer que, ao qualificar o endividamento excessivo como um planejamento fiscal abusivo e reconhecendo o seu caráter de elisão (e não de evasão), buscou o legislador colocar limites ao planejamento tributário por meio de uma norma dita como antielisiva específica.

Não pretendemos questionar a nomenclatura empregada para alguns autores para qualificar as normas contra a subcapitalização, por outro lado, se esse era o real objetivo do legislador, qual seja, coibir eventual forma abusiva de planejamento fiscal, novamente nos parece serem desnecessárias as regras de subcapitalização, visto que uma forma abusiva de planejamento fiscal levaria ao reconhecimento de despesa de juros desnecessária à atividade da empresa, com a única finalidade de gerar economia fiscal e, novamente, as regras existentes anteriormente à Medida Provisória $n^{\circ}$ 472/09 já determinavam a não dedutibilidade das despesas não necessárias à atividade da empresa, conforme visto no item 6.1.1.

Adicionalmente a exposição de motivos se refere à substituição do capital social necessário à constituição da empresa por um empréstimo e, conforme visto no item 6.1.2, os juros sobre o capital próprio têm exatamente como finalidade o desincentivo a essa prática.

Desta forma, podemos repetir a conclusão do item anterior no sentido de que o estudo da regra de despesas necessárias e do instituto dos juros sobre o capital próprio se mostram convincentes no sentido da desnecessidade do estabelecimento de regras de subcapitalização no Brasil.

\subsection{Aplicação de ficção ou presunção absoluta}

Os temas presunção e ficção geram, há muito tempo, debates doutrinários acalorados, havendo divergências relevantes acerca da correta definição de cada um dos termos. 
As divergências doutrinárias chegam ao tema do presente trabalho na medida em que verificamos autores que afirmam que as regras de subcapitalização representam uma presunção absoluta e outros que afirmam que não se trata nem de presunção nem de ficção.

Desta forma, discorreremos brevemente acerca do conceito de ficção e presunção para, posteriormente, buscar firmar posição sobre o assunto.

Em aprofundado estudo sobre os temas ficção e presunção, Luís Eduardo Schoueri relata ser comum encontrar autores que defendem serem as ficções jurídicas uma negação intencional da realidade, pela qual o jurista deveria partir de uma afirmação que ele mesmo saberia não corresponder à verdade, sendo essa linha seguida, por exemplo, por Pontes de Miranda. ${ }^{267}$

Dentre outras teses defendidas por renomados juristas, aponta o autor a tese defendida por Perez de Ayala, Navarrine e Asorey, para quem a ficção não oculta a verdade real, mas o que faz é criar uma verdade jurídica distinta da real. ${ }^{268}$

Refutando as teorias brevemente mencionadas acima, Luís Eduardo Schoueri chega ao que chamou de conceito moderno da ficção jurídica, que dispensa a necessidade de averiguação quanto a sua "verdade real" ou "verdade jurídica", e que leva a conclusão que ficção jurídica é uma norma, através do qual o legislador determina que se aplique, a dada hipótese de incidência (hipótese ficta), determinadas sanções previamente definidas para outra situação (base da ficção). ${ }^{269}$

Nesse sentido, a ficção nunca significou uma afronta à realidade, representando apenas uma remissão normativa, distinguindo-se de outras normas legais exclusivamente por sua forma, nunca por seu conteúdo. Desta forma, o exame da história revela que o conceito de ficção nunca esteve ligado a ideia de mentira, revelando-se como um meio de técnica jurídica pelo qual os fins almejados são alcançados através de equiparação de desiguais, ou da desequiparação de iguais. ${ }^{270}$

\footnotetext{
${ }^{267}$ SCHOUERI, Luis Eduardo. Ob. Cit. (nota 182), p. 99.

${ }^{268}$ SCHOUERI, Luis Eduardo. Ob. Cit. (nota 182), p. 102.

${ }^{269}$ SCHOUERI, Luis Eduardo. Ob. Cit. (nota 182), p. 104.

${ }^{270}$ SCHOUERI, Luis Eduardo. Ob. Cit. (nota 182), p. 104.
} 
O professor segue o raciocínio fazendo remissão a autores nacionais e estrangeiros que seguem a mesma linha, linha de pensamento essa que nos parece de uma clareza e simplicidade impar e que certamente deve guiar qualquer debate acerca do tema ficção.

Relativamente às presunções, faz-se necessário uma primeira distinção, entre as presunções simples e as legais.

A primeira consiste naquela que decorre do raciocínio do magistrado a partir dos fatos apresentados pelo magistrado e, por sua própria natureza, não permitem qualquer conclusão acerca de aspectos subjetivos da hipótese legal; já a segunda, como o próprio nome o diz, decorre de expresso mandamento legal e, através das quais o legislador determina o dever de se inferir, de um fato conhecido, outro cuja ocorrência não é certa. ${ }^{271}$

As presunções legais se distinguem entre relativas e absolutas, conforme a admissibilidade, ou não, de prova em contrário. Tendo em vista que as presunções absolutas se mostram mais relevantes para o tema em estudo, não abordaremos em detalhes as presunções relativas.

Observa Luís Eduardo Schoueri que alguns autores negam a existência de presunções absolutas, tomando por base o direito comparado, o que se mostra um equívoco na medida em que em certos países, mesmo as presunções ditas "absolutas", admitem prova em contrário, através da confissão judicial, tida como probatio probatissima. ${ }^{272}$

Há ainda autores que ao diferenciarem as figuras da presunção absoluta e da ficção a partir da verossimilhança da afirmação, pois, para esses autores, ambas supõem a existência de um fato; uma, entretanto, de um fato que provavelmente é verdadeiro e outra, um fato que certamente não o é. ${ }^{273}$

Buscando esclarecer a diferença entre presunção absoluta e ficção, observa Luís Eduardo Schoueri que a diferença é estrutural: enquanto na ficção diz-se "na presença do

${ }^{271}$ SCHOUERI, Luis Eduardo. Ob. Cit. (nota 182), p. 109-112.

${ }^{272}$ SCHOUERI, Luis Eduardo. Ob. Cit. (nota 182), p. 114.

${ }^{273}$ SCHOUERI, Luis Eduardo. Ob. Cit. (nota 182), p. 115. 
fato B, deve-se agir como se ocorresse o fato A", na presunção é dito "a presença do fato B é prova conclusiva do fato $\mathrm{A} " .{ }^{274}$

Desta forma, entende Luís Eduardo Schoueri que ficções jurídicas e presunções absolutas são categorias jurídicas diversas, mas sua diferenciação independe de questões quanto à veracidade fática da afirmação normativa, pois as últimas estão ligadas à teoria das provas, encontrando-se no âmbito do processo, enquanto a ficção é um instrumento do legislador. $^{275}$

Cumpre esclarece ainda que embora as presunções estejam ligadas à teoria das provas, não são elas mesmas uma norma referente a provas, pois estão ligadas em verdade ao ônus da prova, que determina qual a parte que está obrigada a provar um fato, para que esse possa ser apreciado pelo juiz. ${ }^{276}$

Superada a breve conceituação acerca das figuras ficção e presunção, passamos a analisar o enquadramento das regras de subcapitalização em uma figura ou em outra.

A classificação das regras de subcapitalização como ficção ou presunção mostra-se complexa, sendo possível observar opiniões divergentes acerca do tema.

O autor Alberto Xavier, ao questionar se a lei atribuiu aos juros indedutíveis, por ficção ou presunção legal, a natureza de lucros distribuídos como acontece em legislações estrangeiras, afirma que a lei apenas determina a indedutibilidade, pelo que a assimilação a lucro distribuído restringe-se apenas a esse efeito, junto ao devedor, e a mais nenhum outro, junto ao credor, em suas palavras, "a lei recusou a dedutibilidade de uma despesa, mas não mudou a natureza do rendimento". 277

Quer nos parecer que o autor não enquadra as regras de subcapitalização nem como ficção nem como presunção legal.

\footnotetext{
${ }^{274}$ SCHOUERI, Luis Eduardo. Ob. Cit. (nota 182), p. 116.

${ }^{275}$ SCHOUERI, Luis Eduardo. Ob. Cit. (nota 182), p. 116.

${ }^{276}$ SCHOUERI, Luis Eduardo. Ob. Cit. (nota 182), p. 116.

277 XAVIER, Alberto. Ob. Cit., p. 353.
} 
Por seu turno, Roberto Quiroga Mosquera e Rodrigo de Madureira Pará Diniz tomam posição no sentido das regras de subcapitalização configurarem presunção absoluta, conforme se observa em seu texto:

com efeito, a legislação em questão estabeleceu a presunção absoluta de que as despesas com juros pagos em razão de operações de dívida realizadas com parte vinculada no exterior, quando ultrapassado determinado percentual do patrimônio líquido da pessoa jurídica brasileira, são desnecessárias à consecução das atividades empresariais e, por isso, não são integralmente dedutíveis na apuração do lucro real e na base de cálculo da CSLL. ${ }^{278}$

Concordamos com o posicionamento de Roberto Quiroga Mosquera e Rodrigo de Madureira Pará Diniz, pois entendemos que as normas de subcapitalização se adequam ao conceito de presunção absoluta pelos mesmos fundamentos expostos no texto acima reproduzido, na medida em que o legislador foi bastante objetivo em definir o limite máximo de endividamento e determinar que qualquer despesa de juros decorrente de endividamento superior aos limites legais estabelecidos, deveria ser considerada não necessária às atividades da empresa, não admitindo ainda a possiblidade de prova em contrário.

Definido o enquadramento das regras de subcapitalização como presunção absoluta, avançamos para uma segunda etapa da análise para questionar: a presunção absoluta é compatível com o direito tributário?

Observa-se que alguns autores entendem que as presunções absolutas não podem ser utilizadas em questões tributárias por incompatibilidade com o principio da legalidade, entretanto, conforme esclarecido acima, as presunções estão no campo do direito processual e não no campo do direito material, desta forma, entendemos não existir referida incompatibilidade

Há ainda questionamento quanto à compatibilidade das presunções absolutas com o princípio da ampla defesa e, neste ponto, novamente concordamos com Luís Eduardo

${ }^{278}$ MOSQUERA. Roberto Quiroga e DINIZ, Rodrigo de Madureira Pará. Ob. Cit. (nota 76), p. 400. 
Schoueri que afirma que basta que, em determinado caso, a presunção na exclua a ampla defesa, para que o juiz esteja plenamente amarrado à exigência legal. ${ }^{279}$

Por seu turno, uma das incompatibilidades apontadas por alguns se revela difícil de superar: a conciliação entre as presunções absolutas e o principio da igualdade que, em matéria tributária, se reflete no princípio da capacidade contributiva.

Observamos que o princípio da capacidade contributiva é debatido há bastante tempo, sendo possível encontrar diversas definições para o mesmo. Neste sentido, é interessante a observação de Victor Borges Polizelli que afirma que as discussões em torno do princípio da igualdade e da capacidade contributiva, em geral, tomam como marco inicial as reflexões de grandes pensadores, principalmente a partir do século XVIII, época do desenvolvimento do liberalismo, demonstrando há quanto tempo se debate o tema e o quanto já se questionou a seu respeito. ${ }^{280}$

De maneira bastante simples e direta, observa Paulo Ayres Barreto que a capacidade contributiva é a aptidão da pessoa colocada na posição de destinatário legal tributário, para suportar a carga tributária, sem o perecimento da riqueza lastreadora da tributação e, desta forma, ausente tal aptidão, não se admite, em face do subsistema constitucional tributário brasileiro, se dê a percussão tributária. ${ }^{281}$

Em outras palavras, em virtude de tal princípio, a tributação apenas pode recair sobre fatos que tenham substancia econômica; além disso, dois contribuintes que incorrerem em determinado fato gerador de um tributo estão sujeitos a sua incidência, desde que respeitadas as diferentes capacidades contributivas individuais, quando for $o$ caso. $^{282}$

Tendo em vista o conceito de capacidade contributiva exposto acima, chegamos ao momento de avaliar se é possível conciliar referido conceito com a presunção absoluta.

\footnotetext{
${ }^{279}$ SCHOUERI, Luis Eduardo. Ob. Cit. (nota 182), p. 126.

${ }^{280}$ POLIZELLI, Victor Borges. O princípio da realização da renda - reconhecimento de receitas e despesas para fins do IRPJ - Série doutrina tributária Vol. VII. São Paulo: Quartier Latin, 2012, p. 55.

${ }^{281}$ BARRETO, Paulo Ayres. Ob. Cit., p. 44.

${ }^{282}$ SCHOUERI, Luis Eduardo. Ob. Cit. (nota 182), p. 127.
} 
Tratando-se de presunção absoluta, mais do que mera dispensa, tem-se, a partir da ocorrência da premissa legal (base da presunção), a certeza legal da ocorrência do fato gerador e a consequente proibição de prova em contrário. Desta forma, a prova da ocorrência da base de presunção torna-se suficiente para a ocorrência da tributação. ${ }^{283}$

Em outras palavras, pode-se dizer que em se tratando de presunção absoluta, a subsunção já não se dá entre hipótese de incidência tributária e fato gerador "in concreto", mas entre base de presunção e sua concretização; entretanto, a base de presunção (eleita pelo legislador) não tem necessariamente conteúdo econômico e mesmo que o tenha, não implica, necessariamente, existência de capacidade contributiva. ${ }^{284}$

Desta forma, podemos afirmar que ao estabelecer-se a base de presunção, não necessariamente a tributação irá recair sobre fatos que tenham substância econômica, o que pode levar, inclusive, ao tratamento diferenciado a dois contribuintes que incorrerem em determinado fato gerador de um tributo, sem respeito às diferentes capacidades contributivas individuais.

Considerando a exposição acima, pode-se concluir que a presunção absoluta, quando aplicada em matéria tributária para definição do fato gerador, não é compatível com o principio da igualdade, refletido, em matéria tributária no princípio da capacidade contributiva.

Observamos que é exatamente o que acontece com as regras de subcapitalização estabelecidas no Brasil, pois ao contrário de outras jurisdições e das próprias regras de preços de transferência brasileiras, não admitem que o contribuinte possa demonstrar, no caso concreto, a necessidade de utilização de taxas de juros e níveis de endividamento diversos aos previstos no texto legal, para que a dedutibilidade das correspondentes despesas seja então admitida. ${ }^{285}$

Ramon Tomazela Santos segue a mesma linha e observa que a determinação de um coeficiente fixo de endividamento sem a possibilidade de prova em contrário pelo

\footnotetext{
${ }^{283}$ SCHOUERI, Luis Eduardo. Ob. Cit. (nota 182), p. 127.

${ }^{284}$ SCHOUERI, Luis Eduardo. Ob. Cit. (nota 182), p. 127.

${ }^{285}$ MOSQUERA. Roberto Quiroga e DINIZ, Rodrigo de Madureira Pará. Ob. Cit. (nota 76), p. 404.
} 
contribuinte, viola o conceito de renda e o próprio princípio da capacidade contributiva. Prossegue o autor ainda dizendo que o legislador estabeleceu percentuais fixos de endividamento independentemente da atividade exercida pela pessoa jurídica, contribuindo para o princípio da praticidade, porém em detrimento do princípio da isonomia. ${ }^{286}$

Considerando o exposto até aqui, podemos concluir que as regras de subcapitalização efetivamente correspondente ao conceito de presunção absoluta e, exatamente por esse motivo, mostram-se incompatíveis com o princípio da igualdade que, em matéria tributária, se reflete no princípio da capacidade contributiva.

\subsection{Coeficientes fixos aplicados a todos os setores}

Conforme se observa da leitura dos artigos 24 e 25 da Lei 12.249/10, os limites estabelecidos pelas regras de subcapitalização são aplicados de maneira uniforme a todos os setores da economia, não levando em conta as diferentes necessidades de endividamento.

Conforme já mencionamos no capítulo 3, o próprio relatório da IFA sobre thin capitalization aponta problemas na utilização de coeficientes fixos aplicados a todos os setores e menciona a existência de diferentes níveis de endividamento entre países (como é o caso de Estados Unidos e Japão, por exemplo) e entre os diferentes tipos de indústrias e empresas. $^{287}$

Nesta linha, sugeri Roberto Quiroga Mosquera e Rodrigo de Madureira Pará Diniz que, a luz do princípio da isonomia, que os aludidos coeficientes fixos fossem diversificados em razão das atividades desenvolvidas pelos contribuintes e que, naturalmente, exigem a contratação de operações de dívidas em diferentes níveis. ${ }^{288}$

Concordamos com o relatório da IFA e com os comentários dos autores acima citados visto que não apenas os diferentes setores da economia possuem perfis e níveis de

\footnotetext{
${ }^{286}$ SANTOS, Ramon Tomazela. As regras de subcapitalização introduzidas pela Lei 12.249/10. Revista Dialética de Direito Tributário nº 184. São Paulo: Dialética, 2011, p. 126.

${ }^{287}$ INTERNATIONAL FISCAL ASSOCIATION - IFA. Ob. Cit. (nota 8), p. 111.

${ }^{288}$ MOSQUERA. Roberto Quiroga e DINIZ, Rodrigo de Madureira Pará. Ob. Cit. (nota 76), p. 404.
} 
endividamento distintos, mas por vezes dentro do mesmo setor da economia há diferentes níveis de endividamento em função do estágio de maturidade da empresa, como por exemplo, empresas em fase pré-operacional ou no inicio das atividades possuem necessidade endividamento maior que empresas já estabelecidas e em plena atividade.

Desta forma, caso se admitisse a necessidade da norma (o que entendemos já termos provado não ser o caso), certamente deveria haver revisão da aplicação de coeficientes fixos e iguais aplicados a todos os setores da economia, levando-se em conta as características de cada setor econômico, do tipo de empresa e da fase em que referidas empresas se encontram.

Por seu turno, parece ser bastante improvável que uma regra de defina coeficientes fixos possa contemplar tamanha complexidade de situações, o que nos leva a crer que o caminho adotado pela norma, de adotar coeficientes fixos não foi o mais adequado.

\subsection{Limite de Dedutibilidade x Patrimônio Líquido Negativo ${ }^{289}$}

Conforme já visto anteriormente, os limites de dedutibilidade definidos pelas regras de subcapitalização levam em consideração exclusivamente o valor do patrimônio líquido $\mathrm{e}$, desta forma, qualquer endividamento superior aos limites estabelecidos nos artigos $24 \mathrm{e}$ 25 da Lei 12.249/10 dá ensejo a despesas de juros não dedutíveis.

Por outro lado, uma questão surge da afirmação acima: Qual o limite de endividamento em caso de patrimônio líquido negativo?

A resposta parece bastante direta e objetiva: o limite de endividamento para empresas com patrimônio negativo é zero, seja para endividamento com entidades vinculadas, seja com paraísos fiscais.

Por seu turno, não nos parece ser a melhor solução para o caso em análise, visto que a simples existência de patrimônio líquido negativo mostra-se como um excelente

\footnotetext{
${ }^{289}$ Tendo em vista o escopo limitado do presente trabalho, não abordaremos as discussões relativas aos novos padrões contábeis definidos pela Lei 11.638/07 e seus reflexos para a definição do valor a ser considerado como patrimônio líquido.
} 
indicativo que a empresa passa por dificuldades, visto que os resultados negativos verificados ao longo do período da sua existência excedem ao próprio capital aportado pelos sócios.

Nesta situação, a análise de crédito a ser realizada por qualquer possível credor sem dúvida seria bastante severa, certamente impondo taxas de juros exorbitantes e não compatíveis com qualquer taxa praticada para outros devedores.

Nesse sentido, não nos parece razoável qualquer limitação imposta a endividamentos com entidades ligadas, que certamente fariam análise de crédito menos severa, impondo taxas de juros melhores e, com isso, contribuindo com a continuidade da empresa no Brasil, evitando a sua insolvência e as sempre devastadoras consequências da inadimplência, não apenas para os seus credores, mas para o mercado em geral.

Em outras palavras, a ausência de limite de endividamento com empresas ligadas em casos de patrimônio líquido negativo do tomador do empréstimo, mostra-se como uma situação merecedora de atenção e de uma regra diferenciada, com a valorização da continuidade da empresa, dando-se maior estabilidade ao sistema como um todo.

6.5 Operações com filiais, sucursais e subsidiárias domiciliadas no exterior

Em uma das propostas levadas pelo grupo de trabalho que auxiliou o governo na melhoria da regra de subcapitalização, bem como na regulamentação do tema, constava dispositivo que determinava expressamente que as regras de subcapitalização não se aplicavam às operações com filiais, sucursais ou subsidiárias domiciliadas no exterior.

A justificativa adotada para o dispositivo sugerido é bastante simples e lógica: os rendimentos auferidos pelas filiais, sucursais ou subsidiárias domiciliadas no exterior serão, a posteriore, integralmente tributados pela empresa brasileira (proporcionalmente a participação no caso das subsidiárias).

Independentemente da discussão hoje observada na doutrina e jurisprudência acerca do momento em que referida tributação deve ocorrer (Vide RE 611586 RG / PR - Paraná e 
ADI 2588) ${ }^{290}$, é certo que há previsão expressa para a tributação destes resultados, conforme definido no artigo $1^{\circ}$ da Lei $9.532 / 97$ e normativos posteriores.

Desta forma, não nos parece razoável a imposição de limites ao endividamento com referidas entidades, visto que eventual despesa de juros considerada excedente e, portanto não dedutível, levaria a dupla tributação dos juros, na medida em que os valores excedentes seriam tributados no Brasil e, posteriormente, os resultados auferidos no exterior seriam (novamente) tributados no Brasil.

Em outras palavras, caso os juros decorrentes dos empréstimos concedidos por estas entidades estabelecidas no exterior fossem considerados não dedutíveis (parcialmente ou totalmente), certamente estaríamos de um caso de dupla tributação do imposto de renda sobre o mesmo rendimento.

Adicionalmente, a imposição de limites ao endividamento com essas entidades sediadas no exterior, elimina a própria razão da sua existência, visto que uma das principais razões para sua existência é exatamente a possibilidade de captação de recursos diretamente no exterior, permitindo a obtenção de empréstimos em taxas menores que captações realizadas internamente.

Desta forma, parece razoável a retomada da discussão acerca de estabelecimento de regra especial para os empréstimos concedidos por filiais, sucursais e subsidiárias de empresas brasileiras, domiciliadas no exterior.

6.6 Vigência e eficácia da norma

Passamos a análise de questão bastante relevante e também objeto de intenso debate e críticas: à vigência e eficácia da legislação objeto do presente trabalho.

Porém, antes de verificar a vigência e eficácia da legislação relativa à subcapitalização, torna-se relevante definir a acepção de vigência e eficácia que

${ }^{290}$ A integra dos acórdãos está em:

http://www.stf.jus.br/portal/jurisprudencia/listarJurisprudencia.asp?s1=\%28611586\%2ENUME\%2E+OU+61 586\%2EPRCR\%2E\%29\&base=baseRepercussao\&url=http://tinyurl.com/o9pjyo2. Acessado em 29/08/2013. 
utilizaremos para nossas análises, visto que, conforme afirma Paulo Ayres Barreto, diversos são os modelos adotados pela Dogmática Jurídica para expressar a significação dos termos validade, vigência e eficácia das normas jurídicas. ${ }^{291}$

Em uma concepção genérica, norma válida é aquela que mantém relação de pertinência com o sistema do direito posto; vale dizer, é a norma que foi inserida no ordenamento jurídico pelo órgão credenciado pelo sistema, obedecendo ao procedimento nele (sistema) previsto. ${ }^{292}$

Neste sentido, em pese se tratar de conceito de extrema importância para o direito, não se trata de conceito relevante para a análise que se pretende fazer, visto que nos parece claro que a norma foi inserida no ordenamento jurídico pelo órgão credenciado pelo sistema.

No que se refere ao segundo conceito, a vigência, afirma Paulo Ayres Barreto que vigência é a qualidade que ostenta a norma jurídica que está apta a regular condutas intersubjetivas. É a propriedade de certas regras jurídicas que estão prontas para propagar efeitos, tão logo aconteçam, no mundo social, os fatos descritos em seus antecedentes. Não se confunde com a validade norma - relação de pertinência com o sistema, podendo existir norma válida sem ser vigente. É o que ocorre, v.g., na vacatio legis. ${ }^{293}$

Paulo de Barros Carvalho afirma que "viger é ter força para disciplina, para reger, cumprindo a normas seus objetivos finais. A vigência é a propriedade das regras jurídicas que estão prontas para propagar efeitos, tão logo aconteçam, no mundo fáctico, os eventos que elas descrevem". 294

Luciano Amaro conceitua lei vigente como aquela suscetível de aplicação, desde que se façam presentes os fatos que correspondam à sua hipótese de incidência. ${ }^{295}$

\footnotetext{
${ }^{291}$ BARRETO, Paulo Ayres. Ob. Cit., p. 27.

${ }^{292}$ BARRETO, Paulo Ayres. Ob. Cit., p. 27.

${ }^{293}$ BARRETO, Paulo Ayres. Ob. Cit., p. 28.

${ }^{294}$ CARVALHO, Paulo de Barros. Direito tributário, linguagem e método. São Paulo: Noeses, 2011, p. 449.

${ }^{295}$ AMARO, Luciano. Direito Tributário Brasileiro. São Paulo: Saraiva, 2005, p. 193.
} 
Relativamente ao terceiro conceito, afirma Paulo Ayres Barreto que eficácia jurídica é atributo do antecedente da norma de desencadear os efeitos prescritos no seu consequente. É propriedade do fato jurídico de provocar os efeitos que lhe são próprios. Desta forma, a ocorrência de fato jurídico, vale dizer, fato previsto no antecedente de uma norma jurídica é pressuposto para a propagação de efeitos de direito. A casualidade jurídica exige norma, fato e eficácia. Sem norma, um fato não adquire qualificação de fato jurídico. E sem fato jurídico, efeito (eficácia) nenhum advém. ${ }^{296}$

Pinto Ferreira, denomina de eficácia o poder que têm as normas e os atos jurídicos para a consequente produção de efeitos jurídicos próprios. ${ }^{297}$

Por seu turno, adotando uma linha um pouco diferente dos autores acima referidos, Eurico Marcos Diniz de Santi e Vanessa Rachal Canado afirmam que a vigência de uma norma tributária é a sua aptidão para incidir sobre fatos sociais, ou seja, para constituir o fato gerador. Desta forma, semanticamente, pode-se argumentar que a vigência é equivalente ao conceito de eficácia jurídica da norma, ou seja, uma regra tem eficácia jurídica quando está apta para produzir efeitos sobre a realidade. ${ }^{298}$

Desta forma, considerando que os conceitos de vigência e eficácia adotados por diversos autores, de certa forma se confundem, a linha adotada pelos professores da Fundação Getúlio Vargas parece-nos correta e a que melhor reflete os conceitos em debate, pois resume diversas teorias e simplificam a análise. Neste sentido, adotaremos para fins do presente trabalho esse conceito, onde uma norma é vigente e possui eficácia jurídica quando puder ser aplicada aos casos concretos (constituindo o fato gerador) e gerar, assim, a obrigação de pagar o tributo.

Realizada a delimitação do conceito que se pretende discutir, passamos a discorrer especificamente quanto à aplicação do $\S 2^{\circ}$ do art. 62 da Constituição Federal às regras de subcapitalização e na sequência, sobre a vigência e eficácia das regras, especificamente no que se refere ao imposto de renda e a contribuição social sobre o lucro líquido.

\footnotetext{
${ }^{296}$ BARRETO, Paulo Ayres. Ob. Cit., p. 29.

${ }^{297}$ FERREIRA, Pinto. Curso de Direito Constitucional. São Paulo: Saraiva, 1998, p. 21.

${ }^{298}$ SANTI, Eurico Marcos Diniz de e CANADO, Vanessa Rahal. Ob. Cit., p. 17.
} 
6.6.1 Aplicação do $\S 2^{\circ}$ do art. 62 da Constituição Federal às regras de subcapitalização

Como afirmamos acima, as regras de subcapitalização foram introduzidas em nosso ordenamento jurídico por meio da Medida Provisória nº 472/09. Desta forma, faz-se necessário verificar o que dispõe o artigo 62 da Constituição Federal (vigente à época da publicação da referida medida provisória).

Determina o $\S 2^{\circ}$ do art. 62 da Constituição Federal (com redação dada pela emenda constitucional $\mathrm{n}^{\mathrm{o}} 32$ de 2001):

Art. 62. Em caso de relevância e urgência, o Presidente da República poderá adotar medidas provisórias, com força de lei, devendo submetê-las de imediato ao Congresso Nacional.

(...)

$\S 2^{\circ}$ Medida provisória que implique instituição ou majoração de impostos, exceto os previstos nos arts. 153, I, II, IV, V, e 154, II, só produzirá efeitos no exercício financeiro seguinte se houver sido convertida em lei até o último dia daquele em que foi editada.

(...)

$\S 12$. Aprovado projeto de lei de conversão alterando o texto original da medida provisória, esta manter-se-á integralmente em vigor até que seja sancionado ou vetado o projeto.

Observamos que o $\S 2^{\circ}$ acima reproduzido determina expressamente que medida provisória que implique instituição ou majoração de impostos, só produzirá efeitos no exercício financeiro seguinte ao ano em que for convertida em lei, exceção feita aos casos listados abaixo.

As exceções referidas no parágrafo $2^{\circ}$ são:

Art. 153. Compete à União instituir impostos sobre:

I - importação de produtos estrangeiros;

II - exportação, para o exterior, de produtos nacionais ou nacionalizados;

IV - produtos industrializados;

V - operações de crédito, câmbio e seguro, ou relativas a títulos ou valores mobiliários;

Art. 154. A União poderá instituir:

II - na iminência ou no caso de guerra externa, impostos extraordinários, compreendidos ou não em sua competência tributária, os quais serão suprimidos, gradativamente, cessadas as causas de sua criação.

Como se observa das exceções listadas acima, o imposto de renda, previsto no inciso III do art. 153, não foi excepcionado da regra geral, o que significa dizer que sempre 
que houver instituição ou majoração do imposto de renda deverá, obrigatoriamente, ser observado o disposto no $\S 2^{\circ}$ do art. 62 da Constituição Federal.

Neste ponto, torna-se necessário investigar se o $\S 2^{\circ}$ do art. 62 da Constituição Federal é aplicável aos artigos 24 e 25 da Medida Provisória nº 472, ou em outras palavras, se as regras de subcapitalização implicam instituição ou majoração do imposto de renda e, conseqüentemente, deveriam produzir efeitos no exercício financeiro seguinte à conversão da medida provisória em lei.

Eurico Marcos Diniz de Santi e Vanessa Rachal Canado registram que inúmeras são as discussões sobre os conceitos de despesa normal, usual e necessária, trazidos pelo artigo 47 da Lei $n^{\circ} 4.506$ de 30 de novembro de 1964 e sempre reproduzidos nos regulamentos do imposto de renda (hoje consolidados no art. 299 do Regulamento do Imposto de Renda). ${ }^{299}$

Independentemente da posição que se adote nas diversas discussões, não nos parece razoável afirmar que a não dedutibilidade dos juros pagos a pessoas físicas ou jurídicas, vinculadas ou localizadas em países ou dependências com tributação favorecida ou regime fiscal privilegiado sempre esteve no sistema legal tributário, considerando o conceito atual de despesa normal, usual e necessária.

Observam os professores que a exposição de motivos da MP 472 parece deixar claro que as regras de subcapitalização não são meramente "interpretativas" em relação ao artigo 47 da Lei $n^{\circ} 4.506$ mas, em verdade, trazem novas diretrizes para apuração do lucro real e da base de cálculo da contribuição social que, aplicadas, geram aumento de tributo e reconfiguração do fato gerador, conforme já vimos no item 6.1.3. ${ }^{300}$

Registram ainda os estudiosos que o parecer proferido pelo relator da MP 472 na Câmara (Deputado Marcelo Ortiz) corrobora o entendimento acima ao afirmar categoricamente que os artigos 24 e 25 trazem inovadores dispositivos na legislação tributária. $^{301}$

\footnotetext{
${ }^{299}$ SANTI, Eurico Marcos Diniz de e CANADO, Vanessa Rahal. Ob. Cit., p. 11.

${ }^{300}$ SANTI, Eurico Marcos Diniz de e CANADO, Vanessa Rahal. Ob. Cit., p. 12.

${ }^{301}$ SANTI, Eurico Marcos Diniz de e CANADO, Vanessa Rahal. Ob. Cit., p. 12.
} 
Ramon Tomazela Santos segue a mesma linha ao afirmar que a rigor, as restrições impostas pela Medida Provisória $\mathrm{n}^{\mathrm{o}}$ 472/2009, posteriormente convertida na Lei $\mathrm{n}^{\mathbf{o}}$ 12.249/2010, representam verdadeira majoração da base de cálculo do imposto de renda da pessoa jurídica - IRPJ, pois restringem a dedutibilidade de despesa que ordinariamente seria considerada na apuração do lucro tributável.

A rigor, o conceito de renda pressupõe a tributação somente do acréscimo patrimonial experimentado pelo contribuinte (receita menos despesas), de modo que a restrição à dedutibilidade de certas despesas na apuração do lucro real implicará na majoração do lucro passível de imposição do lucro passível da imposição pelo IRPJ.

Relembra o advogado que o artigo 97, parágrafo $1^{\circ}$ do Código Tributário Nacional equipara a majoração do tributo à modificação da sua base de cálculo, que importe em torná-lo mais oneroso, o que notoriamente ocorreu com a publicação das regras de subcapitalização. ${ }^{302}$

Demonstrada a aplicação das disposições do $\S 2^{\circ}$ do artigo 62 da Constituição Federal às regras de subcapitalização, cabe a verificação se esse dispositivo foi atendido ou não quando do estabelecimento das referidas regras.

\subsubsection{Imposto de Renda}

Conforme demonstramos acima, o $\S 2^{\circ}$ do artigo 62 da Constituição Federal se aplica às regras de subcapitalação.

No que se refere ao imposto de renda, considerando que não dúvidas quanto a sua natureza de imposto, verificamos que referido tributo se adequa perfeitamente a previsão normativa, constante do $\S 2^{\circ}$ do artigo 62 da Constituição Federal.

\footnotetext{
${ }^{302}$ SANTOS, Ramon Tomazela. As regras de Subcapitalização e o Poder Regulamentar da Receita Federal do Brasil - análise crítica da instrução normativa RFB nº 1.154/2011. Revista Dialética de Direito Tributário no 192. São Paulo: Dialética, 2011, p. 111.
} 
Consequentemente, da leitura do dispositivo em referência, pode-se afirmar que no que tange ao imposto de renda, as regras de subcapitalização somente poderiam vigorar ou ter eficácia a partir do exercício financeiro seguinte à conversão em lei da medida provisória que majorou esse tributo.

Não é outro o posicionamento do professor Luís Eduardo Schoueri ao afirmar que após a edição da medida provisória 32/2001, já não haverá hipótese de imposto exigido por força de medida provisória, na medida em que se exige que esta seja convertida em lei, antes que se inicie a cobrança. Daí é que somente a lei - e não a medida provisória - é que dará fundamento para a imposição. ${ }^{303}$

Desta forma, as regras de subcapitalização somente poderiam majorar o imposto de renda a partir do exercício financeiro subsequente a conversão da Medida Provisória nº 472 na Lei $n^{\circ} 12.249$, conversão esta que ocorreu em 11 de junho de 2010, com publicação no diário oficial em 14 de junho de 2010, em outras palavras, as regras de subcapitalização deveriam vigorar, para fins de imposto de renda, apenas no exercício financeiro de 2011.

Ramon Tomazela Santos segue a mesma linha e afirma: "assim, considerando que a conversão da Medida Provisória ${ }^{\circ}$ 472/2009 na Lei $n^{\circ}$ 12.249/2010 somente ocorreu no ano-calendário de 2010 (e não em 2009, quando foi publicada a medida provisória), parece-nos bastante sustentável que as regras para fins de IRPJ surtissem efeitos apenas a partir de $1^{\circ}$ de janeiro de $2011^{\prime \prime 304}$

Não é outra a conclusão dos professores Eurico Marcos Diniz de Santi e Vanessa Rachal Canado que afirmam: "se, como no nosso caso concreto, a conversão em lei só ocorreu no ano seguinte (2010), não há como 'aproveitar' o prazo entre a edição da medida provisória e a conversão em lei; neste caso, o prazo da anterioridade da norma tributária que instituiu ou majora impostos só começa a ser contado a partir da publicação da lei”. 305

Em que pese o entendimento claro exposto acima, não foi esse o posicionamento adotado pelas autoridades fiscais.

\footnotetext{
${ }^{303}$ SCHOUERI, Luís Eduardo. Ob. Cit. (nota 205), p. 91.

${ }^{304}$ SANTOS, Ramon Tomazela. Ob. Cit. (nota 302), p. 111.

${ }^{305}$ SANTI, Eurico Marcos Diniz de e CANADO, Vanessa Rahal. Ob. Cit., p. 14.
} 
A Medida Provisória n ${ }^{\circ}$ 472, datada de 15 de dezembro de 2009 previa que os artigos 24 e 25, que dispõem sobre as regras de subcapitalização, entravam em vigor a partir da data da publicação ocorrida em 16 de dezembro de 2009.

Por seu turno, a Lei $\mathrm{n}^{\mathrm{o}} 12.249$, datada de 11 de junho de 2010, manteve a data de vigência dos citados dispositivos a partir de 16 de dezembro de 2009 sem fazer qualquer ressalva quanto aos novos dispositivos, em que pese todas as mudanças legislativas ocorridas na câmara dos deputados e no senado, modificando de maneira relevante a configuração da norma originalmente estabelecida pela medida provisória $n^{\circ} 472$ e tornando-a exequíivel sob determinados aspectos, conforme relatamos no capítulo 5.

Finalmente, quando da regulamentação da matéria pela receita federal, por meio da instrução normativa $\mathrm{n}^{\mathrm{o}} 1.154$, datada de 12 de maio de 2011 e publicada no diário oficial de 13 de maio de 2011, onde novamente se verificam alterações na norma e dispositivos novos, optaram as autoridades fiscais por simplesmente estabelecer no artigo 14 da instrução normativa que a mesma entra em vigor na data de sua publicação e, da mesma forma que quando da publicação da Lei $n^{\circ} 12.249$, sem fazer qualquer ressalva quanto aos novos dispositivos.

Novamente registramos nossas críticas ao posicionamento das autoridades competentes, tendo sido desrespeitados importantes princípios constitucionais como anterioridade e segurança jurídica na medida em que as normas de subcapitalização tiveram vigência e eficácia a partir de 16 de dezembro de 2009, quando deveriam impactar a base de cálculo do imposto de renda apenas a partir de 01 de janeiro de 2011.

\subsubsection{Contribuição Social sobre o Lucro Líquido}

Como se demonstrou acima, a aplicação do $\$ 2^{\circ}$ do artigo 62 da Constituição Federal ao imposto de renda não apresenta dificuldades de interpretação, não sendo possível afirmar que a aplicação à contribuição social sobre o lucro líquido - CSLL é simples e direta. 
$\mathrm{O} \S 2^{\circ}$ do art. 62 da Constituição Federal determina que medida provisória que implique instituição ou majoração de impostos, produzirá efeitos no exercício financeiro seguinte se houver sido convertida em lei até o último dia daquele em que foi editada.

A partir do momento em que o constituinte apenas faz alusão aos "impostos", cumpre questionar: o silêncio da Constituição traduz implícita proibição da criação e/ou majoração das demais espécies tributárias pela via da medida provisória?

Antes de avançar no comentário, cumpre lembrar as lições de Ezio Vanoni relativas aos métodos de interpretação das leis tributárias:

\begin{abstract}
Desde que as características jurídicas das normas tributárias não se distinguem das demais normas de direito, a opinião que pretende negar aplicabilidade, às leis tributárias, dos mesmos métodos de interpretação que se aplicam às leis em geral parece destituída de qualquer fundamento. As normas tributárias, como quaisquer outras, devem ser interpretadas com o fito de atribuir ao preceito jurídico o valor real que lhe compete na regulamentação das relações da vida que constituem o seu objeto: qualquer orientação apriorística do trabalho interpretativo, a favor do fisco ou a favor do contribuinte, constitui uma inadmissível limitação do processo lógico representado pela interpretação da lei. ${ }^{306}$
\end{abstract}

Verificamos por meio do trecho acima reproduzido que o magistério de Ezio Vanoni afirma que não se deve buscar interpretação a favor do fisco ou a favor do contribuinte antes de uma análise aprofundada do texto legal e do valor real tutelado.

Desta forma, a resposta à questão acima colocada (o silêncio da Constituição traduz implícita proibição da criação e/ou majoração das demais espécies tributárias pela via da medida provisória?) será dada com observância das lições de Ezio Vanoni.

Alexandre Macedo Tavares apresenta uma primeira resposta a essa pergunta, afirmando que o alcance do $\S 2^{\circ}$ do art. 62 da Constituição Federal é sistematicamente limitado, pois a partir do momento que as medidas provisórias correspondem a uma forma excepcional de regular certos assuntos, há de ser necessariamente restrita, não permitindo ao exegeta uma interpretação ampliativa de seus conceitos. ${ }^{307}$

\footnotetext{
${ }^{306}$ VANONI, Ezio. Ob. Cit., p. 181.

${ }^{307}$ TAVARES, Alexandre Macedo. Medida Provisória em Matéria Tributária . : uma análise à luz de marcos condicionantes de hermenêutica jurídica. Florianópolis: Momento Atual, 2005, p. 97.
} 
Referido autor traz julgado interessante do Superior Tribunal de Justiça, tendente a confirmar o seu entendimento:

CONSTITUIÇÃO - ALCANCE POLÍTICO - SENTIDO DOS VOCÁBULOS -
INTERPRETAÇÃO
O conteúdo político de uma Constituição não é conducente ao desprezo do sentido vernacular das
palavras, muito menos ao do técnico, considerados institutos consagrados pelo Direito. Toda ciência
pressupõe a adoção de escorreita linguagem, possuindo os institutos, as expressões e os vocábulos
que a revelam conceito estabelecido com a passagem do tempo, quer por força de estudos
acadêmicos quer, no caso do Direito, pela atuação dos Pretórios.

Ramon Tomazela Santos apresenta entendimento semelhante e afirma que com relação à CSLL, convém ressaltar que os artigos 150, III, "b" e 62 parágrafo $2^{\circ}$ da Constituição Federal não se aplicam às contribuições sociais, as quais estão sujeitas a regras próprias.

Neste sentido, prossegue o advogado, de acordo com o artigo 195, parágrafo $6^{\circ}$ da Constituição Federal, as contribuições sociais somente poderão ser cobradas 90 dias da publicação da lei que as houver instituído ou aumentado e, com base nisso, as regras de subcapitalização deveriam ser aplicadas a partir de 16 de março de 2010 para fins de apuração da base de cálculo da CSLL. ${ }^{309}$

Em contraposição ao posicionamento de Alexandre Macedo Tavares e Ramon Tomazela Santos, verificamos que Paulo Roberto Lyrio Pimenta afirma em seu texto As medidas provisórias em direito tributário: inovações da Emenda Constitucional no 32: “o signo 'imposto' apresenta, neste caso, a acepção de 'tributos". ${ }^{310}$ Em outras palavras, entende o autor, que o parágrafo $2^{\circ}$ do artigo 62 da Constituição Federal se aplica integralmente a qualquer tributo e não apenas aos impostos.

Desta forma, segundo Paulo Roberto Lyrio Pimenta, na medida em que as disposições do parágrafo $2^{\circ}$ do artigo 62 da Constituição Federal se aplicam integralmente à CSLL, as regras de subcapitalização deveriam ser aplicadas a partir de $1^{\circ}$ de janeiro de

\footnotetext{
${ }^{308}$ Supremo Tribunal Federal. Recurso Extraordinário no 166.772/RS, Pleno, Rel. Min. Marco Aurélio, julgado em 12 de maio de 1994, Diário Oficial da Justiça, 16 de dezembro de 1994.

${ }^{309}$ SANTOS, Ramon Tomazela. Ob. Cit. (nota 302), p. 112.

310 PIMENTA, Paulo Roberto Lyrio. As medidas provisórias em direito tributário: Inovações da Emenda Constitucional n 32. Revista Dialética de Direito Tributário nº 77. São Paulo: Dialética, 2001, p. 104.
} 
2011 para fins de apuração da base de cálculo da CSLL, da mesma forma que ocorre com o imposto de renda.

Eurico Marcos Diniz de Santi e Vanessa Rachal Canado percorrem caminho diferente de Paulo Roberto Lyrio Pimenta, porém concluem da mesma forma. Os autores abordam o tema em detalhes e afirmam que as contribuições possuem fato gerador idêntico aos impostos: atuação de particular que denota capacidade contributiva e, no caso particular do IRPJ e da CSLL há ainda uma maior coincidência, pois ambos incidem sobre o lucro das pessoas jurídicas.

Segundo os professores, o que diferenciam as contribuições dos impostos e, neste caso, o IRPJ da CSLL, é a destinação dada ao produto da arrecadação, pois os impostos não tem destinação específica, ao contrário da arrecadação das contribuições (que deve seguir ao destino que fundamentou a sua criação). No caso da CSLL, sua destinação específica é a seguridade social, sendo esse critério - e somente esse - que diferencia a CSLL do IRPJ.

Como conclusão, entendem os autores que a análise do texto dos pressupostos de "relevância e urgência" da MP 472 demonstra não haver qualquer referencia ao déficit da previdência ou à necessidade de aumento da arrecadação da CSLL para a seguridade social, havendo referência apenas ao aprimoramento do fato gerador "lucro" coincidente no caso do IRPJ e da CSLL, não havendo assim justificativa para a aplicação do art. 62, parágrafo $2^{\circ}$ da $\mathrm{CF} / 88$ unicamente ao IRPJ.

Em outras palavras, para os autores, a vigência das regras de subcapitalização deveria ocorrer a partir de 01 de janeiro de 2011, tanto para apuração da base de cálculo do imposto de renda, quanto para apuração da base de cálculo da contribuição social sobre o lucro líquido. ${ }^{311}$

Em que pese a razoabilidade dos argumentos apresentados do Eurico Marcos Diniz de Santi e Vanessa Rachal Canado, bem como por Paulo Roberto Lyrio Pimenta, entendemos que o parágrafo $2^{\circ}$ do art. 62 da Constituição Social deve ser lido de maneira

\footnotetext{
${ }^{311}$ SANTI, Eurico Marcos Diniz de e CANADO, Vanessa Rahal. Ob. Cit., p. 14.
} 
restritiva e não buscando uma interpretação mais favorável ao contribuinte, o que significa dizer que essa regra se aplica exclusivamente ao imposto de renda.

Desta forma, considerando que em nosso entendimento, a regra disposta no parágrafo $2^{\circ}$ do art. 62 da Constituição Federal não se aplica à contribuição social sobre o lucro líquido, não sendo esse o dispositivo adequado a definir a anterioridade aplicável as demais espécies tributárias (diferentes de impostos), se questiona qual seria o dispositivo aplicável e qual a data que deveriam entrar em vigor as regras de subcapitalização, para fins de CSLL.

Nesse sentido, entendemos que o dispositivo constitucional que regula a anterioridade aplicável às contribuições sociais é o $§ 6^{\circ}$ do artigo 195 que assim dispõe:

Art. 195. A seguridade social será financiada por toda a sociedade, de forma direta e indireta, nos termos da lei, mediante recursos provenientes dos orçamentos da União, dos Estados, do Distrito Federal e dos Municípios, e das seguintes contribuições sociais:

$\S 6^{\circ}$ - As contribuições sociais de que trata este artigo só poderão ser exigidas após decorridos noventa dias da data da publicação da lei que as houver instituído ou modificado, não se lhes aplicando o disposto no art. 150, III, "b".

Roque Antônio Carrazza segue linha semelhante e afirma que as contribuições sociais que financiarão a seguridade social não foram postas ao largo do princípio da anterioridade. Elas, na verdade, devem obedecer a uma anterioridade especial, já que só poderão ser exigidas depois de decorridos noventa dias da data da publicação da lei que as houver instituído ou modificado. ${ }^{312}$

Esclarece o autor: "portanto, uma vez entrada em vigor a lei que criar ou aumentar estes tributos, terá eficácia noventa dias após, sem levar em conta o exercício financeiro" e ilustra os seus comentários com dois exemplos:

1) Se a lei criar uma contribuição social para a seguridade social em $1^{\circ}$ de março, este ato normativo incidirá sobre fatos que vierem a ocorrer a partir de $1^{\circ}$ de junho (no mesmo exercício financeiro, mas noventa dias após);

2) Se uma lei criar esta mesma figura exacional no dia 31 de dezembro, incidirá a partir de $1^{\circ}$ de abril do ano seguinte (próximo exercício financeiro, mas - sempre - noventa dias após). ${ }^{313}$

\footnotetext{
${ }^{312}$ CARRAZZA, Roque Antonio. Curso de Direito Constitucional Tributário. São Paulo: Malheiros, 2008, p. 203.

${ }^{313}$ CARRAZZA, Roque Antonio. Ob. Cit., p. 203.
} 
Ante a redação acima reproduzida, bem como os comentários e exemplos do professor Roque Antônio Carrazza, entendemos que as regras de subcapitalização somente poderiam afetar a base de cálculo da contribuição social depois de transcorrido 90 dias da publicação da Medida Provisória n 472, que ocorreu em 16 de dezembro de 2009, em outras palavras, a vigência deveria ocorrer, para fins de CSLL, a partir de 16 de março de 2010 .

Novamente somos compelidos a registrar nossas críticas à postura adotada pelas autoridades competentes, pois as normas de subcapitalização tiveram vigência e eficácia a partir de 16 de dezembro de 2009, quando deveriam impactar a base de cálculo da contribuição social sobre o lucro líquido apenas a partir de 16 de março de 2010. 


\section{CONCLUSÃO}

O processo de globalização impôs uma nova dinâmica ao comercio mundial, especialmente aos grupos econômicos, impondo novos desafios aos legisladores.

Dentre os novos desafios apresentados, mostra-se relevante a necessidade de verificação da adequação dos preços praticados entre partes relacionadas a fim de que se certifique que não está havendo transferência indevida de resultados entre essas partes relacionadas.

A verificação dos preços praticados entre partes relacionadas tem sido realizada primordialmente por regras de safe harbour e arm's length.

Além da verificação dos preços praticados entre partes relacionadas, outro desafio para os reguladores é a forma de constituição das empresas ao redor do mundo e a estrutura de capital adotada, qual seja, capital próprio ou capital de terceiros.

Por haver uma percepção mundial que havia abuso na utilização de capital de terceiros para a constituição de empresas ou capitalização de empresas já existentes, diversos países passaram a adotar regras tendentes a evitar a chamada subcapitalização.

O Brasil buscou seguir o modelo adotado em diversos países e adotou, ainda que tardiamente, regras para evitar a subcapitalização.

Em que pese o Brasil ter adotado regras contra a subcapitalização, o estudo do ordenamento jurídico prévio ao estabelecimento das referidas regras demonstra que não havia necessidade de estabelecimento das mesmas, visto que já havia dispositivos no ordenamento jurídico suficientes para evitar o endividamento excessivo.

Além da constatação que os dispositivos já existentes no ordenamento jurídico pátrio à época da publicação da Medida Provisória nº 472/09, que estabeleceu as regras de subcapitalização no Brasil, já se mostravam suficientes para evitar o endividamento excessivo, a medida provisória publicada, posteriormente convertida em lei bem como a 
sua regulamentação foram inseridos em nosso ordenamento jurídico com uma série de lacunas, equívocos e pontos passíveis de reparo.

Dentre as imperfeições das regras, é possível citar a aplicação de coeficientes fixos a todos os setores da economia, ausência de regra específica para situações de patrimônio líquido negativo e transações com filiais, sucursais e subsidiárias de empresas brasileiras sediadas no exterior, bem como aplicação imediata da Medida Provisória, sem observância de regras de anterioridade.

Após todas as análises realizadas no presente estudo, ficamos convencidos acerca da necessidade de revisão das regras para evitar a subcapitalização estabelecidas no Brasil, remanescendo a esperança que as autoridades competentes possam reabrir o diálogo com as entidades representativas da sociedade e buscar melhores soluções. 


\section{BIBLIOGRAFIA}

- AMARO, Luciano. Direito Tributário Brasileiro. São Paulo: Saraiva, 2005.

- ANDRADE FILHO, Edmar Oliveira. Imposto de renda das empresas. São Paulo: Atlas, 2004.

- AVI-YONAH, Reuven S. International tax as international law. New York: Cambrige University Press, 2007.

. e Clausing, Kimberly. "Reforming Corporate Taxation in a Global Economy: A proposed to Adopt Formulary Apportionment". Acessado em 08 de agosto de 2011 em Tax Justice Network: http://webcache.googleusercontent.com/search?q=cache:yh2c6iEncw4J:www.taxjustic e.net/cms/front_content.php\%3Fidcat\%3D139+The+Arm's+Length+Principle+oecd\&c $\mathrm{d}=11 \& \mathrm{hl}=\mathrm{pt}-\mathrm{BR} \& \mathrm{ct}=\mathrm{clnk} \& \mathrm{gl}=\mathrm{br} \&$

- $\quad$ ATALIBA, Geraldo. Hipótese de Incidência Tributária. São Paulo: Malheiros, 2004.

- BALEEIRO, Aliomar. Direito tributário brasileiro. $11^{\circ}$ ed. Atualizada por Misabel Abreu Machado Derci. Rio de Janeiro: Forense, 2001.

- BARRETO, Paulo Ayres. Imposto sobre a renda e preços de transferência. São Paulo: Dialética, 2001.

- BERCOVICI, Gilberto. Constituição Econômica e desenvolvimento: uma leitura a partir da Constituição de 1988. São Paulo: Malheiros Editores. 2005.

- BIFANO, Elidie Palma. Estruturações de operações no mercado financeiro e o tema do planejamento tributário. In: MOSQUERA, Roberto Quiroga (coord.). O direito tributário e o mercado financeiro e de capitais. São Paulo: Dialética, 2010. v.2.

- BISPO, Rafael Minervino. As regras de subcapitalização no direito tributário brasileiro. Dissertação (Mestrado em Direito) - Pontifícia Universidade Católica de São Paulo - PUC-SP, São Paulo, 2012.

- BOBBIO, Norberto. Teoria do Ordenamento Jurídico. Tradução de Maria Celeste C. J.

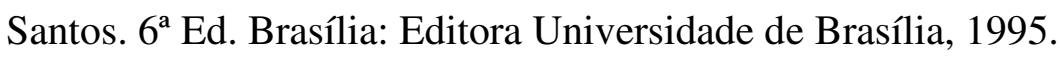

- CANTO, Fabio Ulhôa. "A participação nos resultados das Companhias (Dividendos e Juros sobre o Capital Próprio) e os Direitos dos Acionistas Minoritários”. In Aspectos atuais do direito do mercado financeiro e de capitais. $2^{\circ}$ Volume. São Paulo: Dialética, 2000 . 
- CARRAZZA, Roque Antonio. Curso de Direito Constitucional Tributário. São Paulo: Malheiros, 2008.

- CARVAlHO, Paulo de Barros. Curso de Direito Tributário. 22 a edição. São Paulo: Saraiva, 2010.

Saraiva, 2000.

Curso de Direito Tributário $13^{\mathrm{a}}$ ed.,rev. e atual. São Paulo:

- $\quad$ Direito tributário, linguagem e método. São Paulo: Noeses, 2011.

- COELHO, Fabio Ulhôa. Curso de Direito Comercial - direito das empresas. Vol. 2, $14^{\circ}$ Ed. São Paulo: Saraiva, 2010.

- CORONADO, Luis; CHEUNG, Patrick e Kyte, Justin. An overview of arm's length approaches to thin capitalization. International transfer pricing journal - Journals IBFD. Vol. 17, $\mathrm{n}^{\circ}$ 4. Amsterdam, 2010.

- DIB, Roberta Augusta Assad. The new Brazilian thin capitalization rules and how the other BRICs approach the subject. Bulletin for international taxation - Journals IBFD. Vol. 64, nº 6. Amsterdam, 2008.

- DÓRIA, Antônio Roberto Sampaio. Elisão e Evasão Fiscal. São Paulo: Livraria dos Advogados Editora Ltda., 1971.

- ELALI, André de Souza Dantas. Tributação e regulação econômica: um exame da tributação como instrumento de regulação econômica na busca da redução das desigualdades. São Paulo: MP Editora, 2007.

- Equipe de Professores da FEA/USP. Contabilidade Introdutória. São Paulo: Atlas, 1998.

- $\quad$ ERNST \& YOUNG. The 2011 worldwide corporate tax guide. EYGM, 2011.

- FARIA, José Eduardo. O direito na economia globalizada. São Paulo: Malheiros, 2004.

- FERRAZ Junior, Tércio Sampaio. Teoria da Norma Jurídica. 4a ed. Rio de Janeiro: Forense, 2009.

- FERREIRA, Pinto. Curso de Direito Constitucional. São Paulo: Saraiva, 1998.

- GALHARDO, Luciana Rosanova e LOPES Junior, Jorge Ney de Figueiredo. As regras de subcapitalização e a atuação de bancos nacionais e estrangeiros na estruturação de operações de financiamento externo de empresas nacionais. In MOSQUERA, Roberto Quiroga (coord.). O direito tributário e o mercado financeiro e de capitais. São Paulo: Dialética, 2010, v.2. 
- GASPARINI, Diógenes. Direito Administrativo. 5 ed., ver. atual. e aum. São Paulo: Saraiva, 2000.

- GÉNÉREUX, Jacques. Introdução à política econômica. Tradução Maria Stela Gonçalves e Adail Ubirajara Sobral. São Paulo: Editora Loyola, 1995.

- GOYOS Junior, Durval de Noronha. Paraísos Fiscais: Planejamento Tributário Internacional. São Paulo: Observador Legal, 1988.

- GREGORIO, Ricardo Marozzi. Arm's length e praticabilidade nos preços de transferência. 2010. Tese (Doutorado em Direito) - Faculdade de Direito, Universidade de São Paulo, São Paulo, 2010.

- GRUPENMACHER, Betina Treiger. Tratados Internacionais em matéria tributária e ordem interna. São Paulo: Dialética, 1999.

- GUZMAN, Antonio Carlos Marchetti e PENIDO, Tatiana Morais. “As Regras de Subcapitalização e sua Aplicação no Ordenamento Jurídico Brasileiro". In: JUNIOR, Pedro Luciano Marrey et al. Sinopse Tributária 2010-2011. São Paulo: Impressão Régia, 2010.

- HATTINGH, Johann. South Africa - Corporate Taxation. Sec. 10 - Country Analyses IBFD. Amsterdam, 2011.

- HORTA, Nereida de Miranda Finamore. As regras de Thin Captalization e a exclusão de operações de repasses realizadas pelas instituições financeiras. In MOSQUERA, Roberto Quiroga (coord.). O direito tributário e o mercado financeiro e de capitais. São Paulo: Dialética, 2010, v.2.

- INTERNATIONAL FISCAL ASSOCIATION - IFA. "International aspects of thin capitalization”. In Cahiers de Droit Fiscal International. Vol. 81b. Geneva: IFA, 1996. provisions. In Cahiers de Droit Fiscal International. Vol. 95a. Geneva: IFA, 2010.

- KELSEN, Hans. Teoria Pura do Direito. Tradução de João Baptista Machado. São Paulo: Martins Fontes, 1998.

- LARA, José Edson e MESQUITA, José Marcos Carvalho. Estrutura de Capital e Rentabilidade: análise do desempenho de empresas Brasileiras no período pós Plano Real. In Revista Contabilidade Vista e Revista. v. 19, n. 2.Belo Horizonte: Universidade Federal de Minas Gerais, 2008.

- LATORRACA, Nilton. Direito Tributário - Imposto de Renda das Empresas. São Paulo: Atlas, 1998. 
- LERMER, David. South Africa - Recent Developments. In Transfer Pricing and Thin Capitalization. International transfer pricing journal - Journals IBFD. Vol. 18, $\mathrm{n}^{\mathrm{o}} 2$. Amsterdam, 2011.

- LIMA, Mariana Miranda. A natureza jurídica dos juros sobre o capital próprio e as convenções para evitar a dupla tributação. 2009. Dissertação (Mestrado em Direito) Faculdade de Direito, Universidade de São Paulo, São Paulo, 2009.

- LUND, Henrik; KORSGAARD, Carina Marie e ALBERTSEN, Mathias. Financing: a global survey of thin capitalization and transfer pricing rules in 35 selected countries. International transfer pricing journal. - Journals IBFD. Vol. 15, nº 6. Amsterdam, 2008.

- MA, Shiqi. China (People's Rep.) - Corporate Taxation. Sec. 1 - Country Analyses IBFD: Amsterdam, 2011.

- MACHADO, Antônio Cláudio da Costa e QUEIROZ, Mary Elbe (coords.). Código Tributário Nacional Interpretado. São Paulo: Manole, 2010.

- MACHADO, Hugo de Brito, "A supremacia constitucional e o imposto de renda", estudos sobre o imposto de renda - em memória de Henry Tilbery. Editora Resenha Tributária, 1994, p. 56 in OLIVEIRA, Ricardo Mariz de. Fundamentos do Imposto de Renda. São Paulo: Quartier Latin, 2008.

- MIFANO, Flavio e ABREU, José Mauricio Carvalho. “A isenção ao imposto sobre a renda no repasse de dividendos por fundos de investimento". In: JUNIOR, Pedro Luciano Marrey et al. Sinopse Tributária 2010-2011. São Paulo: Impressão Régia, 2010.

- MINATEL, José Antonio. Conteúdo do Conceito de Renda. São Paulo: MP Editora, 2005.

- MOREIRA Junior, Gilberto de Castro. O Fenômeno da Bi-tributação Internacional. In Revista de Direito Tributário da APET. Ed. 07. São Paulo: MP, 2005.

- MOSQUERA, Roberto Quiroga (coord.). O direito tributário e o mercado financeiro e de capitais. São Paulo: Dialética, 2010.

- $\longrightarrow$ Aspectos atuais do direito do mercado financeiro e de capitais. $2^{\circ}$ Vol. São Paulo: Dialética, 2000.

- Renda e proventos de qualquer natureza - $\mathrm{O}$ imposto e o conceito constitucional. São Paulo: Dialética, 1996.

e PICONEZ, Matheus Berthiolo. Tratamento Tributário dos Instrumentos Financeiros Híbridos. In: MOSQUERA, Roberto Quiroga e LOPES, 
Alexsandro Broedel (coord.). Controvérsias jurídico-contábeis (aproximações e distanciamentos). $2^{\circ}$ Vol. São Paulo: Dialética, 2011.

Subcapitalização no Direito Brasileiro - Questões Controversas”. In: ROCHA, Valdir de Oliveira (coord.). Grandes Questões Atuais do Direito Tributário. 15º Vol. São Paulo: Dialética, 2011, p. 392.

- NESS JUNIOR, Walter Lee; ZANI, João. Os juros sobre o capital próprio versus a vantagem fiscal do endividamento. Revista de Administração, v. 36, nº 2, abr./jun. 2001.

- OBUOFORIBO, Belema. United Kingdom - Corporate Taxation. Sec. 1 - Country Analyses. Amsterdam, 2011.

- OLIVEIRA, Ricardo Mariz de. Fundamentos do Imposto de Renda. São Paulo: Quartier Latin, 2008.

- OLIVEIRA, Antônio Cláudio Mariz de e CAMPOS, DEJALMA (coords.). Direito penal tributário contemporâneo. São Paulo: Atlas, 1996.

- ORGANISATION FOR ECONOMIC CO-OPERATION AND DEVELOPMENT OECD. Harmful tax competition. Paris: OECD, 1998.

- Model Tax Convention on Income and on Capital - Condensed Version. Paris: OECD, 2010.

- Thin Capitalization. (adopted by the OECD Council on 26 November 1986). Paris: OCDE, 2010.

- $\quad$. Transfer Pricing Guidelines for Multinational Enterprises and Tax Administrations. Paris: OECD, 2010.

- PACÍFICO, Andréa Maria Calazans Pacheco. Os tratados Internacionais e o Direito Constitucional brasileiro. $1^{\circ}$ Ed. Brasília: Brasília Jurídica, 2002.

- PIMENTA, Paulo Roberto Lyrio. As medidas provisórias em direito tributário: Inovações da Emenda Constitucional n ${ }^{\circ} 32$. Revista Dialética de Direito Tributário no 77. São Paulo: Dialética, 2001.

- PINTO, Gustavo Mathias Alves. Tratados Internacionais em matéria tributária e sua relação com o direito interno no Brasil. Revista Direito GV, São Paulo, v.4 n.1 Jan-Jun. 2008.

- POHLMANN, Marcelo Coletto e IUDÍCIBUS, Sérgio de. Tributação e política tributária: uma abordagem interdisciplinar. São Paulo: Atlas, 2006. 
- POLACCO, Giuliana. How Italy's new thin-capitalization rules work. International tax review. Vol. 15, n 2. London, 2004.

- POLIZELLI, Vitor Borges. "Progressividade: Distribuição de Renda e Indução". In Direito Tributário Atual, vol. 21. São Paulo: Dialética, 2007.

- - O princípio da realização da renda - reconhecimento de receitas e despesas para fins do IRPJ - Série doutrina tributária Vol. VII. São Paulo: Quartier Latin, 2012.

- PRATS, Francisco Alfredo Garcia. "Qualificação dos Instrumentos Financeiros Híbridos em Tratados Fiscais" - Tradução de Célia Korn. In Direito Tributário Atual, vol. 26. São Paulo: Dialética, 2011.

- ROBERT, Eric. France - Corporate Taxation. Sec. 1 - Country Analyses IBFD. Amsterdam, 2011.

- ROBLES, Arturo Pérez. México - Corporate Taxation. Sec. 7 - Country Analyses IBFD. Amsterdam, 2011.

- ROCHA, Valdir de Oliveira (coord.). Grandes questões atuais do direito tributário. 10a Ed. São Paulo: Dialética, 2006.

. Grandes questões atuais do direito tributário. 13 ${ }^{\mathrm{a}}$ Ed. São Paulo:

Dialética, 2009.

- ROLIM, João Dácio. “A remuneração do capital próprio das pessoas jurídicas e a revogação da correção monetária de balanço pela Lei n 9.249/95". In Repertório IOB de jurisprudência, nº 16, 2 quinz. ago. São Paulo: 1996.

- SALOMÃO Neto, Eduardo. Direito Bancário. São Paulo: Atlas, 2005.

- SANTI, Eurico Marcos Diniz de e CANADO, Vanessa Rahal. Vigência e Eficácia das Novas Regras de Subcapitalização. Revista Dialética de Direito Tributário no 192. São Paulo: Dialética, 2011.

- SANTOS, Ramon Tomazela. As Regras de Subcapitalização e o Poder Regulamentar da Receita Federal do Brasil - Análise Crítica da Instrução Normativa RFB no 1.154/2011. Revista Dialética de Direito Tributário no 192. São Paulo: Dialética, 2011. As regras de subcapitalização introduzidas pela Lei 12.249/10. Revista Dialética de Direito Tributário nº 184. São Paulo: Dialética, 2011.

- SCAVONE Junior, Luiz Antonio. Juros no direito brasileiro. $3^{\circ}$ ed. ver., atual. e amp. São Paulo: Revista dos Tribunais, 2003. 
- SHAMANOVA, Evgeniya. Rússia - Corporate Taxation. Sec. 7 - Country Analyses IBFD. Amsterdam, 2011.

- SCHOUERI, Luís Eduardo. Distribuição Disfarçada de Lucros. São Paulo: Dialética, 1996.

- ormas tributárias indutoras e intervenção econômica. Rio de Janeiro : Forense, 2005.

- —. Preços de Transferência no direito tributário brasileiro. $2^{\circ}$ Ed. Rev. e Atual. São Paulo: Dialética, 2006.

- $\quad$ Direito Tributário. São Paulo: Saraiva, 2011.

. Juros sobre Capital Próprio: Natureza jurídica e forma de apuração diante da "nova contabilidade". In: MOSQUERA, Roberto Quiroga e LOPES, Alexsandro Broedel (coord.). Controvérsias jurídico-contábeis (aproximações e distanciamentos). $3^{\circ}$ Vol. São Paulo: Dialética, 2012.

- SILBER, Simão Davi. "A globalização dos mercados". In: VASCONCELLOS, Marco Antônio Sandoval de; LIMA, Miguel; SILBER, Simão Davi (org.). Gestão de Negócios Internacionais. $2^{\circ}$ Ed. São Paulo: Saraiva, 2010.

- SOUSA, Rubens Gomes de. O fato gerador do imposto de renda. In: "Estudos de Direito Tributário”. São Paulo: Saraiva, 1950.

- SUSARLA, Kamesh. India - Corporate Taxation. Sec. 1 - Country Analyses IBFD. Amsterdam, 2011.

- TAVARES, Alexandre Macedo. Medida Provisória em Matéria Tributária . : uma análise à luz de marcos condicionantes de hermenêutica jurídica. Florianópolis: Momento Atual, 2005.

- TORRÉ, Abelardo. Introducción al derecho. 14ª Ed. Buenos Aires: Abeledo Perrot, 2003.

- TÔRRES, Heleno. Pluritributação Internacional sobre as Rendas de Empresas. $2^{\mathrm{a}}$ ed. rev. atual. e amp. São Paulo: Revista dos Tribunais, 2001.

- UTUMI, Ana Claudia Akie. O regime tributário brasileiro do imposto sobre a renda de não-residente - A fonte como critério de conexão. Tese (Doutorado em Direito) Faculdade de Direito, Universidade de São Paulo, São Paulo, 2005.

- VANONI, Ezio. Natureza e interpretação das leis tributárias. Tradução de Rubens Gomes de Sousa. Rio de Janeiro: Edições Financeiras, 1932. 
- VICENTINI, Marcelo Fonseca. Thin Capitalization e seus Impactos para Bancos. In MOSQUERA, Roberto Quiroga (coord.). O direito tributário e o mercado financeiro e de capitais. São Paulo: Dialética, 2010. v.2.

- XAVIER, Alberto. Direito Tributário Internacional do Brasil. $7^{\mathrm{a}}$ ed. Rio de Janeiro: Forense, 2010.

- WEBBER, Stuart. Thin Capitalization and Interest Deduction Rules: A Worldwide Survey. Tax notes international - falls church. Vol. 60. $\mathrm{n}^{\circ}$ 9. 2010.

- ZILVETI, Fernando Aurélio. "Variações sobre o princípio da neutralidade no direito tributário internacional", in Direito Tributário atual, v. 19.

. Princípios de direito tributário e a capacidade contributiva. São Paulo: Quartier Latin, 2004.

- WALD, Arnold. “Alguns Aspectos Jurídicos da Globalização Financeira”. In: MOSQUERA, Roberto Quiroga (coord.). Aspectos Atuais do direito do mercado financeiro e de capitais. São Paulo: Dialética, 1999. 